\section{OsTin}

OAK RIDGE

NATIONAL

LABORATORY

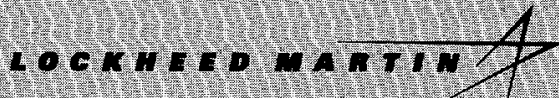

\section{THE ENERGY-RELATED INVENTIONS PROGRAM: \\ CONTINUING BENEFITS TO THE INVENTOR COMMUNITY}

Robert B. Braid, Jr.

Marilyn A. Brown

C. Robert Wilson

Charlotte A. Franchuk

Colleen G. Rizy

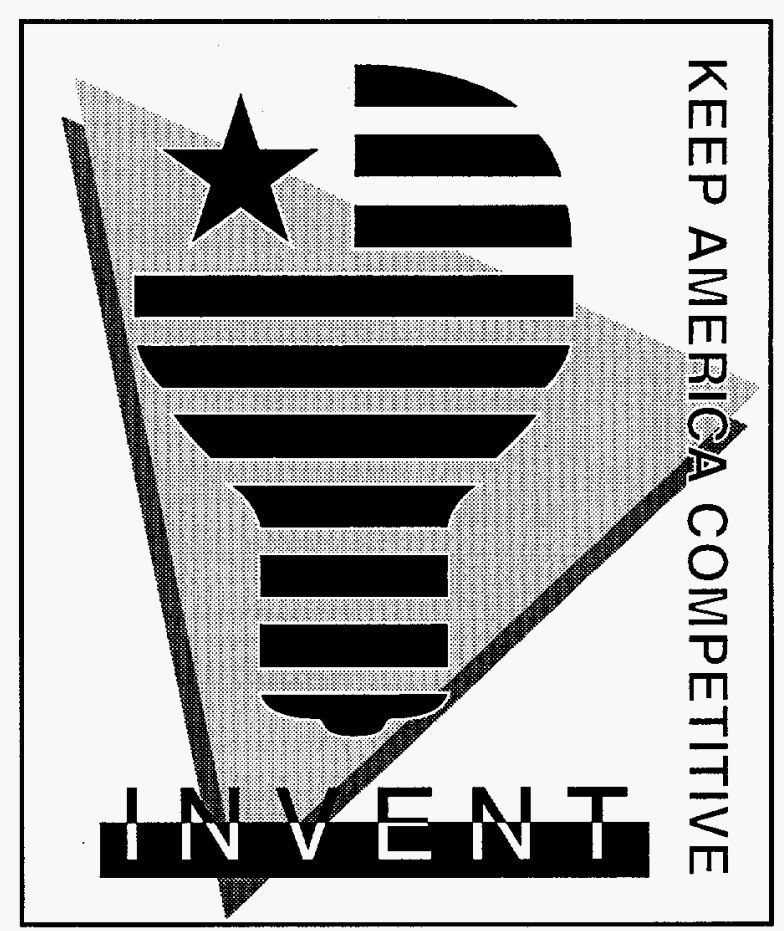

MANGED ANO OPERATEO BY

LOCKHEEO WRTW ENERGY RESEARCH CORPORATION FOR THE UTHED STATES

DEPARTENT OF EIEROY

DISTREUTION OF THIS DOCUMENT IS UNLMITE

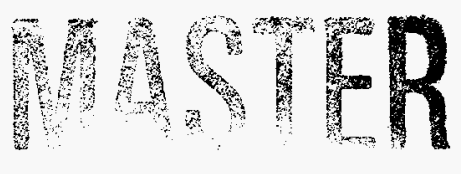


This report has been reproduced directly from the best available copy.

Available to DOE and DOE contractors from the Otfice of Scientific and Technical Information, P.O. Box 62, Oak Ridge, TN 37831; prices available from (423) 576-8401, FTS 626-8401.

Available to the public from the National Technical Information Service, U.S. Department of Commerce, 5285 Port Royal Rd., Springfield, VA 22161.

This report was prepared as an account of work sponsored by an agency of the United States Government. Neither the United States Government nor any agency thereof, nor any of their employees, makes any warranty, express or implied, or assumes any legal liability or responsibility for the accuracy, completeness, or usefulness of any information, apparatus, product, or process disclosed, or represents that its use would not infringe privately owned rights. Reference herein to any specific commercial product, process, or service by trade name, trademark, manufacturer, or otherwise, does not necessarily constitute or imply its endorsement, recommendation, or favoring by the United States Government or any agency thereof. The views and opinions of authors expressed herein do not necessarily state or reflect those of the United States Government or any agency thereof. 
Energy Division

\title{
THE ENERGY-RELATED INVENTIONS PROGRAM: CONTINUING BENEFITS TO THE INVENTOR COMMUNITY
}

\author{
Robert B. Braid, Jr. \\ Marilyn A. Brown \\ C. Robert Wilson \\ Charlotte A. Franchuk \\ Colleen G. Rizy
}

October 1996

Prepared for the

Office of Energy Efficiency and Renewable Energy

U.S. Department of Energy

\author{
Prepared by the \\ Oak Ridge National Laboratory \\ Oak Ridge, TN 37831-6205 \\ managed by \\ LOCKHEED MARTIN ENERGY RESEARCH CORP. \\ for the \\ U.S. DEPARTMENT OF ENERGY \\ under contract number DE-AC05-96OR22464
}




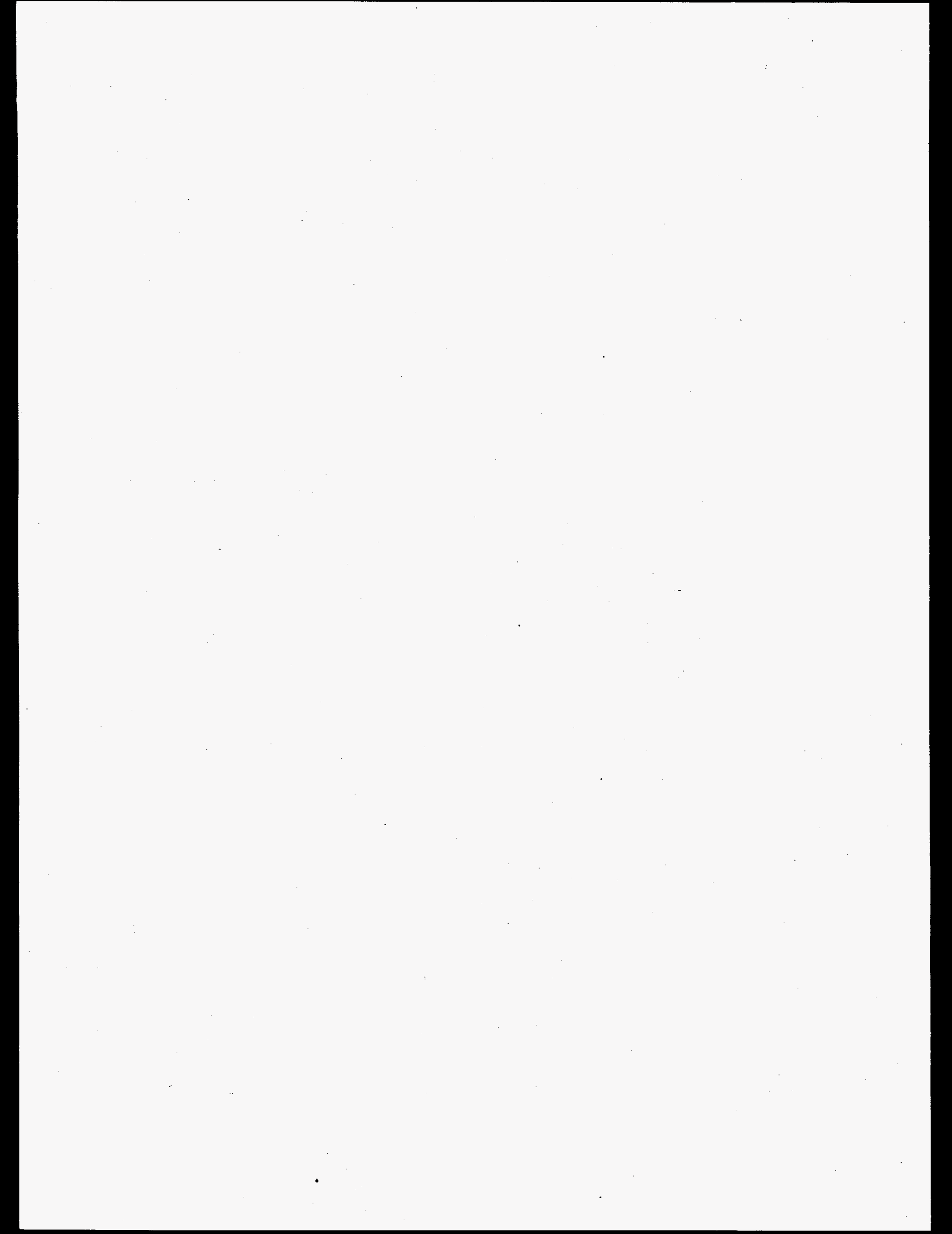




\section{DISCLAIMER}

Portions of this document may be illegible in electronic image products. Images are produced from the best available original document. 
LIST OF TABLES $\ldots \ldots \ldots \ldots \ldots \ldots \ldots \ldots \ldots \ldots \ldots \ldots \ldots \ldots \ldots \ldots \ldots \ldots \ldots$

LIST OF FIGURES $\ldots \ldots \ldots \ldots \ldots \ldots \ldots \ldots \ldots \ldots \ldots \ldots \ldots \ldots \ldots \ldots \ldots \ldots \ldots \ldots \ldots \ldots$

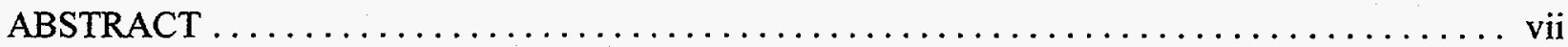

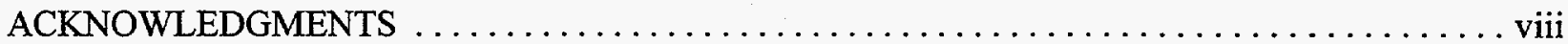

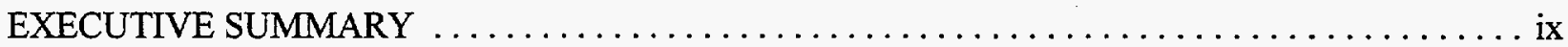

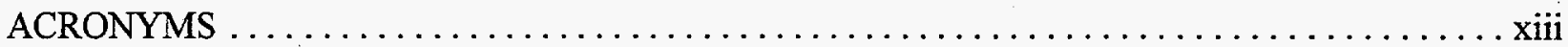

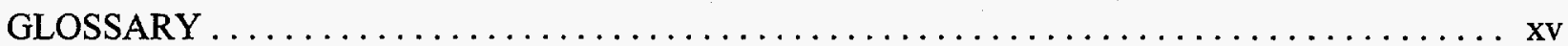

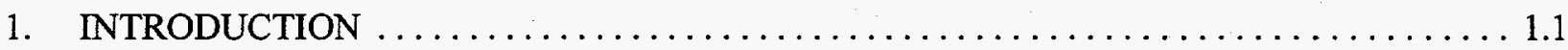

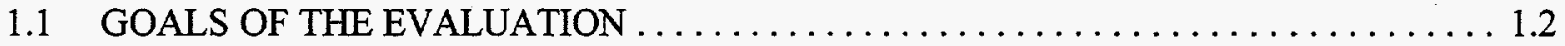

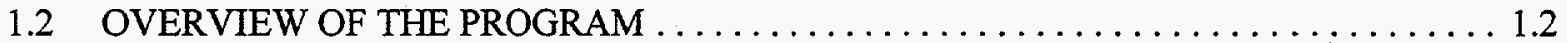

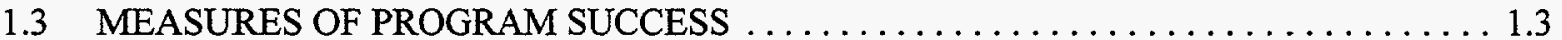

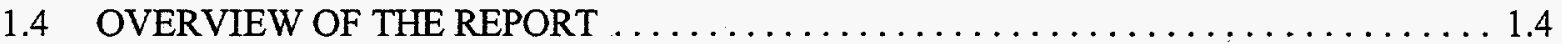

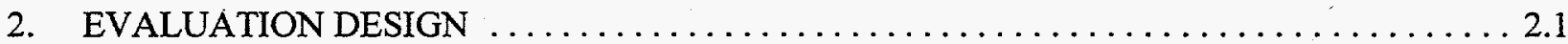

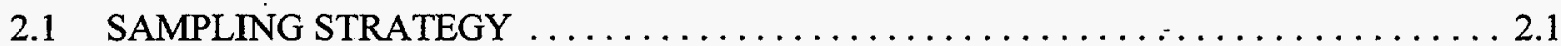

2.2 INTERNAL AND EXTERNAL VALIDITY OF THE EVALUATION $\ldots \ldots \ldots \ldots \ldots 2.3$

3. COMMERCIAL PROGRESS OF ERIP INVENTIONS $\ldots \ldots \ldots \ldots \ldots \ldots \ldots \ldots \ldots \ldots \ldots \ldots \ldots$

3.1 CURRENT STATUS OF ERIP INVENTIONS $\ldots \ldots \ldots \ldots \ldots \ldots \ldots \ldots \ldots \ldots \ldots \ldots \ldots \ldots$

3.2 NUMBER OF ERIP INVENTIONS WITH SALES $\ldots \ldots \ldots \ldots \ldots \ldots \ldots \ldots \ldots \ldots .3$

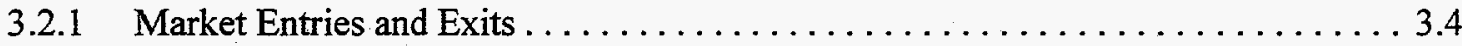

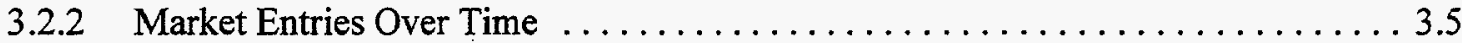

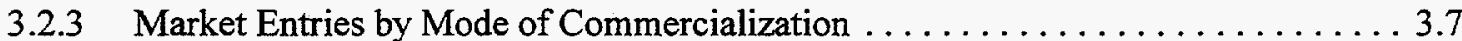

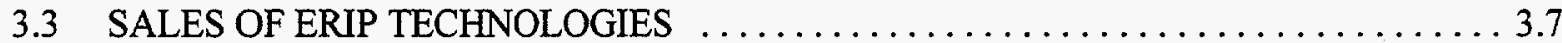

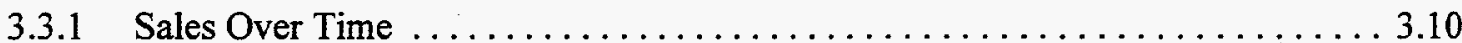

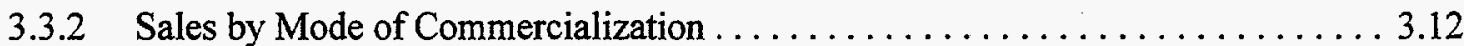

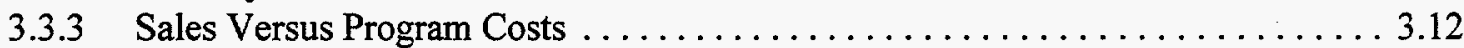

3.4 ROYALTIES FROM LICENSED ERIP TECHNOLOGIES $\ldots \ldots \ldots \ldots \ldots \ldots \ldots \ldots .13$

3.5 COMMERCIALIZATION DIFFICULTIES FACED BY ERIP INVENTORS $\ldots \ldots \ldots 3.14$

4. COMMERCIAL PROGRESS OF SPINOFF TECHNOLOGIES $\ldots \ldots \ldots \ldots \ldots \ldots \ldots \ldots \ldots .1$

4.1 DEFINITION AND CLASSIFICATION OF SPINOFF TECHNOLOGIES $\ldots \ldots \ldots \ldots 4.1$

4.2 ILLUSTRATIONS OF SPINOFFS FROM ERIP TECHNOLOGIES $\ldots \ldots \ldots \ldots \ldots \ldots .2$

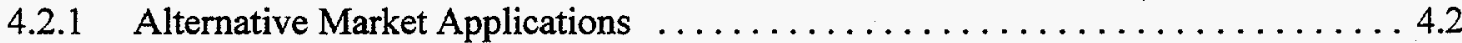

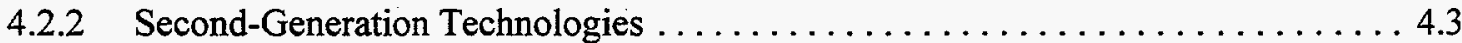

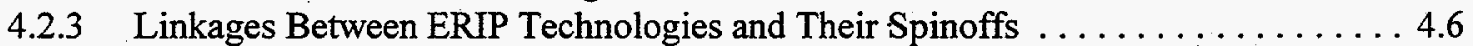

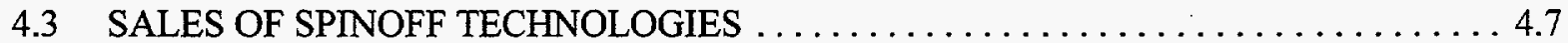




\section{TABLE OF CONTENTS}

5. EMPLOYMENT, TAX REVENUES, AND EXPORTS $\ldots \ldots \ldots \ldots \ldots \ldots \ldots \ldots \ldots . . \ldots .1$

5.1 EMPLOYMENT ASSOCIATED WITH ERIP TECHNOLOGIES $\ldots \ldots \ldots \ldots \ldots \ldots . .1$

5.2 TAX REVENUES FROM ERIP-GENERATED EMPLOYMENT $\ldots \ldots \ldots \ldots \ldots \ldots .5 .5$

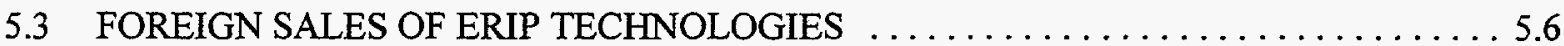

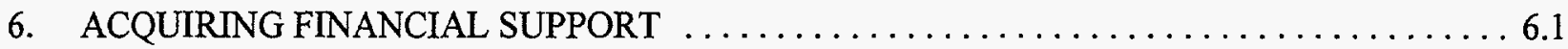

6.1 THE NATURE OF ERIP'S FINANCIAL ASSISTANCE $\ldots \ldots \ldots \ldots \ldots \ldots \ldots \ldots .1$

6.2 THE COST OF TECHNOLOGICAL INNOVATION $\ldots \ldots \ldots \ldots \ldots \ldots \ldots \ldots . .6 .3$

6.3 SOURCES OF FINANCING FOR ERIP INVENTIONS $\ldots \ldots \ldots \ldots \ldots \ldots \ldots \ldots .6 .8$

6.4 IMPACT OF ERIP GRANTS ON PRIVATE SECTOR CAPITAL MARKETS $\ldots \ldots \ldots 6.12$

6.5 THE ERIP GRANT AND ACQUISITION OF NON-ERIP FUNDING $\ldots \ldots \ldots \ldots \ldots 6.14$

7. ENERGY SAVINGS AND ENVIRONMENTAL BENEFITS $\ldots \ldots \ldots \ldots \ldots \ldots \ldots \ldots .1$

7.1. THE RANGE OF ERIP TECHNOLOGY BENEFITS $\ldots \ldots \ldots \ldots \ldots \ldots \ldots \ldots \ldots .1$

7.2 ENERGY SAVINGS OF THREE ERIP-SUPPORTED TECHNOLOGIES $\ldots \ldots \ldots \ldots .7 .2$

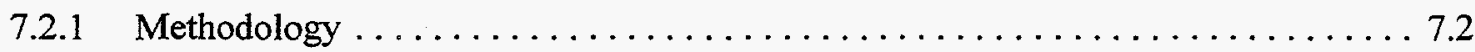

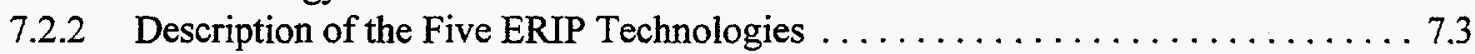

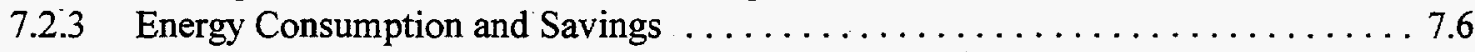

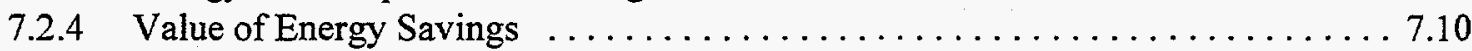

7.3 REDUCTION OF GREENHOUSE GAS EMISSIONS $\ldots \ldots \ldots \ldots \ldots \ldots \ldots \ldots .7 .11$

8. PARTICIPANT PERCEPTIONS AND EVALUATION CONCLUSIONS $\ldots \ldots \ldots \ldots \ldots \ldots .1$

8.1 PARTICIPANT PERCEPTIONS $\ldots \ldots \ldots \ldots \ldots \ldots \ldots \ldots \ldots \ldots \ldots \ldots \ldots \ldots .1$

8.2 RECEIPT OF AN ERIP GRANT, GRANT SIZE, AND THE PERFORMANCE

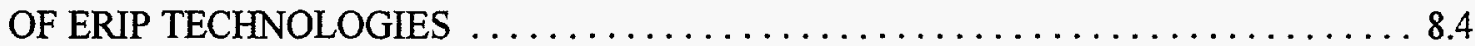

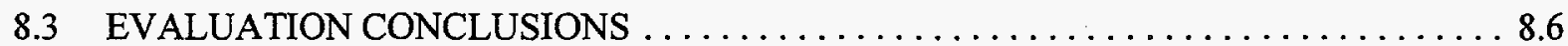

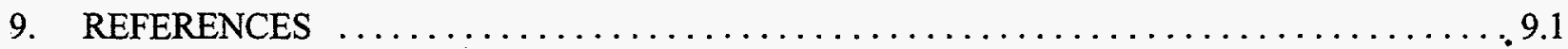

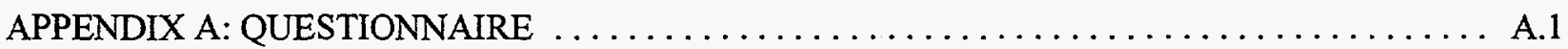

APPENDIX B: ERIP MARKET ENTRIES AND EXITS $\ldots \ldots \ldots, \ldots \ldots \ldots \ldots \ldots \ldots \ldots$ B. 1

APPENDIX C: SUPPORTING DATA $\ldots \ldots \ldots \ldots \ldots \ldots \ldots \ldots \ldots \ldots \ldots \ldots \ldots \ldots \ldots \ldots \ldots \ldots \ldots \ldots$ 
Table E.1 Indicators of Program Impacts $\ldots \ldots \ldots \ldots \ldots \ldots \ldots \ldots \ldots \ldots \ldots \ldots \ldots \ldots \ldots \ldots$

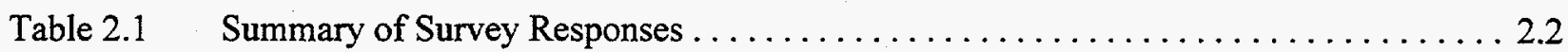

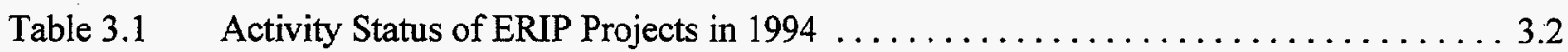

Table 3.2 Stage of Development of ERIP Projects in $1994 \ldots \ldots \ldots \ldots \ldots \ldots \ldots \ldots \ldots \ldots$

Table 3.3 Number of ERIP Technologies with Sales by Date of DOE Receipt $\ldots \ldots \ldots \ldots .6$

Table 3.4 Grants, Program Appropriations, and Cumulative Reported Sales . . . . . . . . 3.9

Table 3.5 Sales of ERIP Technologies by Date of DOE Receipt $\ldots \ldots \ldots \ldots \ldots \ldots \ldots \ldots .11$

Table 3.6 Commercialization Difficulties Faced by ERIP Inventors $\ldots \ldots \ldots \ldots \ldots \ldots \ldots$

Table 5.1 Number of Full-Time Equivalent (FTE) Job Years Sustained by

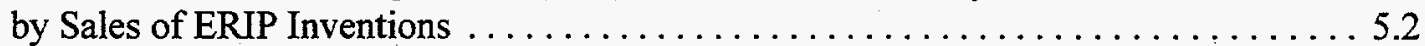

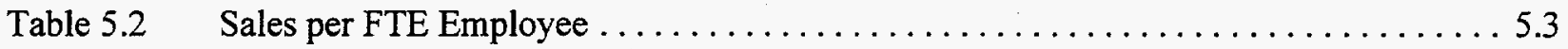

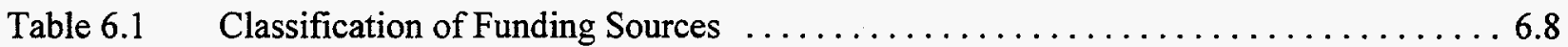

Table $7.1 \quad$ ERIP Technology Benefits to Users and the Public $\ldots \ldots \ldots \ldots \ldots \ldots \ldots \ldots \ldots$

Table 7.2 Energy Savings, in Trillions of Btu $\ldots \ldots \ldots \ldots \ldots \ldots \ldots \ldots \ldots \ldots \ldots \ldots \ldots \ldots \ldots \ldots \ldots \ldots$

Table 7.3 Energy Savings by Fuel Type for Five Technologies in $1994 \ldots \ldots \ldots \ldots \ldots . . .7$

Table 7.4 Energy Savings, in Trillions of Btu, in $1994 \ldots \ldots \ldots \ldots \ldots \ldots \ldots \ldots$

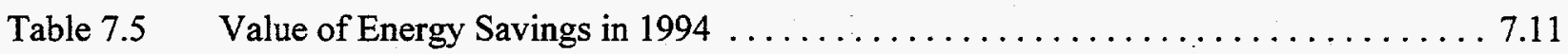

Table 7.6 Reduction in Carbon Emissions in 1994, in Metric Tons . . . . . . . . . . . . 7.12

Table 7.7 Reduction in Methane Emissions in 1994, in Metric Tons . . . . . . . . . . . 7.12

Table 7.8 Reductions in Emissions of $\mathrm{CO}_{2}$ Equivalents from Carbon and Methane . . . . . . 7.12

Table $8.1 \quad$ Participant Perceptions of ERIP Services $\ldots \ldots \ldots \ldots \ldots \ldots \ldots \ldots \ldots \ldots \ldots \ldots \ldots$

Table 8.2 Project Performance Versus Receipt of ERIP Grant and Grant Size $\ldots \ldots \ldots \ldots .6$

Table C.1 Total Annual Royalties from Sales of ERIP Technologies . . . . . . . . . C.3

Table C.2 Yearly Sales of Spinoff Technologies $\ldots \ldots \ldots \ldots \ldots \ldots \ldots \ldots \ldots \ldots \ldots$ C.4

Table C.3 Average Funds Raised per Inventor, by Source $\ldots \ldots \ldots \ldots \ldots \ldots \ldots \ldots \ldots$ C.5 


\section{LIST OF FIGURES}

Fig. E.1 Cumulative sales of ERIP inventions and spinoff technologies $\ldots \ldots \ldots \ldots \ldots \ldots \ldots$ xiv

Fig. 3.1 ERIP inventions entering, in, and exiting the market, by year $\ldots \ldots \ldots \ldots \ldots \ldots \ldots .4$

Fig. 3.2 Modes of commercialization used by 165 ERIP inventions $\ldots \ldots \ldots \ldots \ldots \ldots \ldots \ldots$

Fig. 3.3 Distribution of cumulative sales for ERIP technologies through $1994 \ldots \ldots \ldots \ldots \ldots .10$

Fig. 3.4 Sales by licencing, new venture and existing company $\ldots \ldots \ldots \ldots \ldots \ldots \ldots \ldots \ldots \ldots$

Fig. 3.5 Cumulative grant awards, program appropriations, and sales of ERIP technologies. . . . 3.13

Fig. 3.6 Cumulative royalties from ERIP technologies $\ldots \ldots \ldots \ldots \ldots \ldots \ldots \ldots \ldots \ldots \ldots \ldots \ldots$

Fig. 4.1 A market application spinoff of an ERIP technology $\ldots \ldots \ldots \ldots \ldots \ldots \ldots \ldots \ldots \ldots .4$

Fig. 4.2 A second-generation ERIP technology directed toward existing markets $\ldots \ldots \ldots \ldots .5$

Fig. 4.3 Spinoffs generated from a core technology along both market

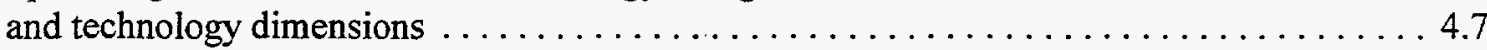

Fig. 4.4 Cumulative sales of 44 spinoff technologies $\ldots \ldots \ldots \ldots \ldots \ldots \ldots \ldots \ldots \ldots \ldots \ldots$

Fig. 5.1 Number of job years sustained by ERIP technologies, 1985 to $1994 \ldots \ldots \ldots \ldots \ldots .4$

Fig. 5.2 Distribution of FTE's for ERIP technologies supporting jobs in $1994 \ldots \ldots \ldots \ldots \ldots \ldots .5$

Fig. 6.1 Distribution of funds raised by 211 inventors, exclusive of ERIP grants $\ldots \ldots \ldots \ldots .4$

Fig. 6.2 Average funds raised before and after the ERIP grant 182 technologies with grants

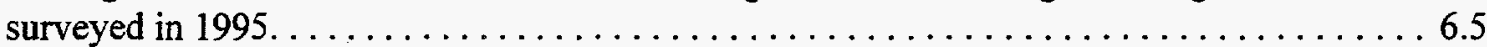

Fig. 6.3 Leverage ratios for all funds raised by ERIP inventors. $\ldots \ldots \ldots \ldots \ldots \ldots \ldots \ldots \ldots$

Fig. 6.4 Leverage ratios for all funds raised by ERIP inventors after receipt of the ERIP award. . . 6.7

Fig. 6.5 Funding sources for ERIP inventions without sales. $\ldots \ldots \ldots \ldots \ldots \ldots \ldots \ldots \ldots .9$

Fig. 6.6 Funding sources for ERIP inventions with sales. $\ldots \ldots \ldots \ldots \ldots \ldots \ldots \ldots \ldots \ldots$

Fig. 6.7 Post-award use of private sector capital markets. $\ldots \ldots \ldots \ldots \ldots \ldots \ldots \ldots \ldots \ldots .13$

Fig. 7.1 Illustration of Brandon steam turbine packing rings $\ldots \ldots \ldots \ldots \ldots \ldots \ldots \ldots \ldots \ldots$

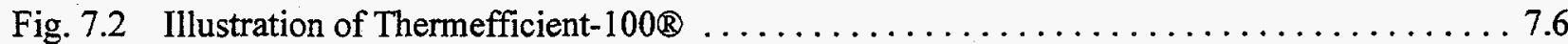

Fig. 8.1 Distribution of ERIP grant size for 475 projects $\ldots \ldots \ldots \ldots \ldots \ldots \ldots \ldots \ldots \ldots$

Fig. 8.2 Cumulative sales of ERIP inventions and spinoff technologies $\ldots \ldots \ldots \ldots \ldots \ldots \ldots .7$ 


\begin{abstract}
This report provides information on the economic, energy, and environmental impacts of inventions supported by the Energy-Related Inventions Program (ERIP) - a technology commercialization program jointly operated by the U.S. Department of Energy (DOE) and the National Institute of Standards and Technology (NIST). It describes the results of the latest in a series of ERIP evaluation projects that have been completed since 1980. The period of interest is 1980 through 1994. The evaluation is based on data collected in 1995 through mail and telephone surveys of 211 program participants, and historical data collected during previous evaluations for an additional 253 participants.

As of September 1993, a total of 609 inventions had been recommended to DOE by NIST, which screens all submitted inventions for technical merit, potential for commercial success, and potential energy impact. By the end of 1994, at least 144 (or $24 \%$ ) of these inventions had entered the market, generating total cumulative sales of $\$ 961$ million (in 1994-\$). It is estimated that in 1994 ERIP inventors earned royalties of $\$ 2.3$ million, and over the lifetime of the program, royalties total $\$ 28.2$ million (1994-\$). With $\$ 47.5$ million in grants awarded from 1975 through 1994 and \$124 million in program appropriations over the same period, ERIP has generated a 20:1 return in terms of sales values to grants, and an 8:1 return in sales versus program appropriations.

Further, it is estimated that at least 757 job-years of employment were supported by ERIP technologies in 1994, and that this resulted in a return of approximately $\$ 3.4$ million in individual income taxes to the U.S. Treasury. Finally, approximately $\$ 334$ million of energy expenditures were saved in 1994 as a result of the commercial success of five ERIP projects. These energy savings resulted in reduced emissions of 2.1 million metric tons of carbon in 1994 alone. Comparisons between these performance indicators and measures of the success of other technology innovation programs suggest that ERIP has been a cost-effective government investment.
\end{abstract}


First of all we would like to thank the inventors who graciously agreed to be suveyed as part of this research. Without their willingness to share their experiences with us, this evaluation would not have been possible.

We would also like to acknowledge the valuable ideas provided by numerous reviewers who commented on earlier drafts of this report. These include: Fred Hart, Philip Hayes, and Terry Levinson (DOE); George Lewett (NIST); Harold Livesay (Texas A\&M); David S. Lux (Bryant College); Marcia Rorke (Mohawk Research Corp.); Barry Bozeman (Georgia Institute of Technology); and Bob Perlack (ORNL). 


\section{EXECUTIVE SUMMARY}

This report presents the results of an evaluation of the economic impacts of the Energy-Related Inventions Program (ERIP), a technology commercialization program jointly operated by the U.S. Department of Energy (DOE) and the National Institute of Standards and Technology (NIST). The evaluation was undertaken primarily to obtain up-to-date information on the commercial progress of ERIP inventions-including the market entry of ERIP technologies and the resulting sales and jobs. In addition, the evaluation seeks to: (1) estimate the energy and environmental benefits of ERIP technologies, (2) document and assess the amount and sources of funds that have been used to develop ERIP inventions, and (3) identify other commercial products that have spun off from ERIP projects.

As of September 1993, a total of 609 inventions were recommended to DOE by NIST, which screens all submitted inventions in terms of technical merit, likelihood of commercial success, and potential energy impact. To reduce the cost of data collection while maximizing the coverage of successful ERIP technologies, a sampling design involving two subsamples was employed. The first subsample includes 98

inventions identified by past research and key informants to be most promising in terms of market entry and commercial success. The second subsample contained the remaining 352 inventions. An attempt was made to reach all 450 inventors, but a special effort was made to contact the subsample of 98 promising inventors. A further 159 inventors were dropped from the 1995 survey because they either were no longer involved in pursuing their invention, could not be located, or chose not to respond to earlier surveys.

A 14-page questionnaire was developed to collect sales, employment, fund-raising, and other data. Ultimately, survey data were collected from 211 inventors (80 promising inventors and 131 of the other inventors), or $47 \%$ of the 450 ERIP inventors surveyed. Most of the surveys were conducted by mail $(\mathrm{N}=171)$, and the remaining $(\mathrm{N}=40)$ by telephone. Historic information from previous evaluations is also available for 253 additional inventors, bringing the total sample size to 464 of the 609 inventions.

Analysis of the survey data produces several performance metrics.

- By the end of 1994 , at least 144 ERIP technologies had entered the market, representing a $24 \%$ commercialization rate.

- These 144 technologies generated total cumulative sales of $\$ 961$ million (1994-\$).

- In 1994 ERIP inventors earned royalties of $\$ 2.3$ million. Over the lifetime of the program, royalties total $\$ 28.2$ million. 
- With $\$ 47.5$ million in grants awarded from 1975 through 1994 , and $\$ 124$ million in program appropriations over the same period, ERIP has generated a 20:1 return in terms of sales values to grants and a 8:1 ratio of sales to program appropriations.

Program appropriations cover the cost of grants provided to inventors, the NIST technical review of program applications, workshops for inventors, technical assistance, grant processing, and program evaluation:

An analysis of spinoff technologies provides numerous examples of derivative Program impacts. Over time, spinoff technologies have grown in importance as by-products of the Program. Altogether, 52 spinoff technologies have generated sales of $\$ 88$ million (in 1994-\$). Most of these involve alternative market applications, but some of them are second-generation technologies. Thus, the Program's total cumulative sales exceed $\$ 1$ billion (1994-\$) when the sales of ERIP's spinoffs are included. Figure E.1 portrays the cumulative sales of ERIP inventions and spinoff technologies over the lifetime of the program, and compares these values to ERIP program appropriations and grants.

During earlier years of the Program, the market entry of ERIP technologies far outpaced the market exits. Since 1984, the number of technologies entering the market each year has been approximately counterbalanced by the exit of older technologies from the market. Through this process, the total number

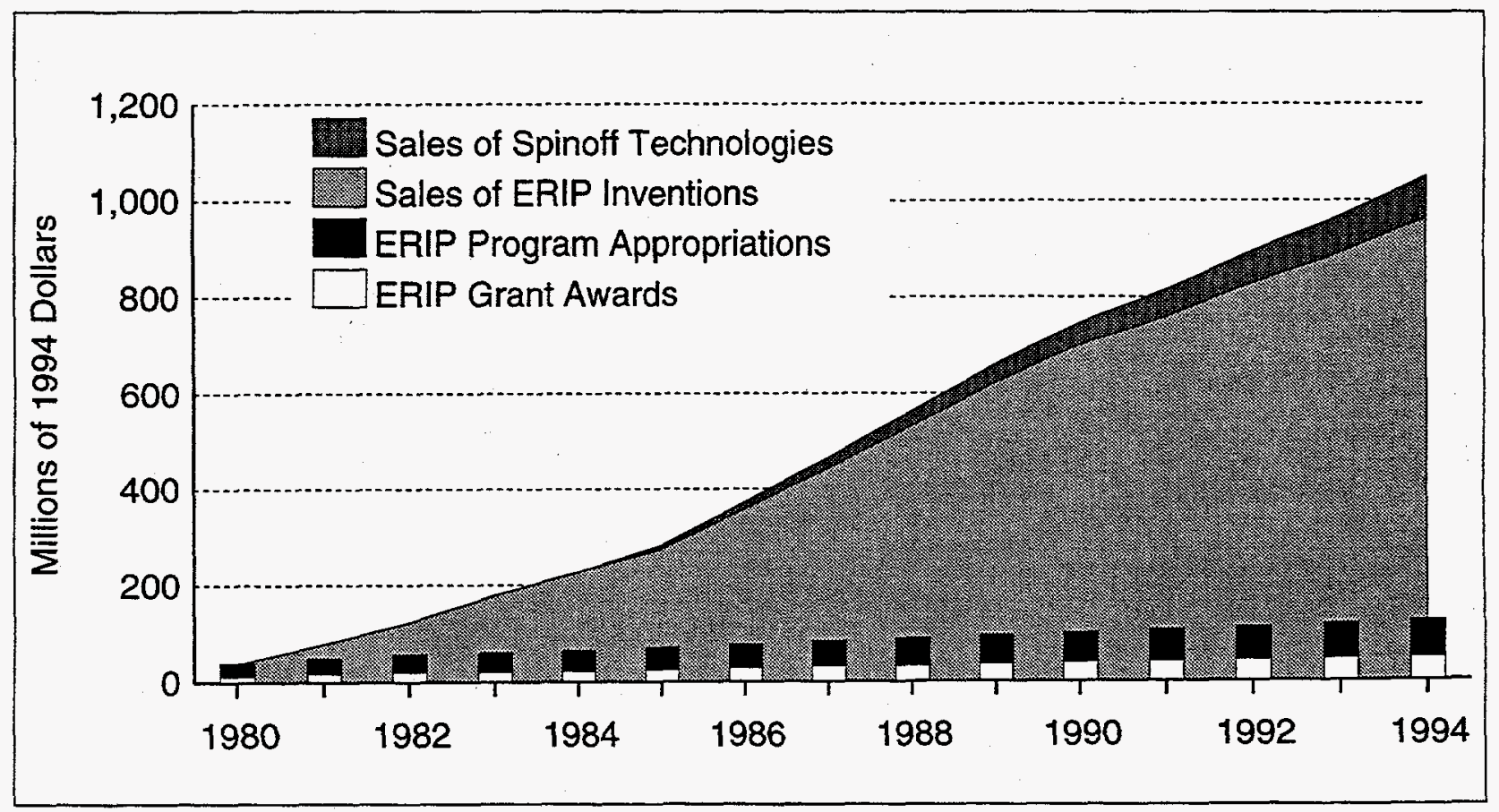

Fig. E.1 Cumulative sales of ERIP inventions and spinoff technologies. 
of technologies in the marketplace in any one year has remained relatively stable-ranging from 50 to 70. Nevertheless, fewer ERIP technologies were in the market between 1991 and 1994 than in the $1988-1990$ period, indicating a slight slow-down in the commercial success of ERIP technologies. This may reflect the general economic downturn experienced by the U.S. during the early 1990 s as well as the steady decline of energy prices over the past decade.

In addition to creating new businesses, products, and sales, ERIP participants have also produced significant employment and tax benefits.

- At least 757 job-years of employment were directly supported by ERIP technologies in 1994 and 6,646 were directly supported over the latest 10 -year period.

- Assuming the national per capita earnings for these workers, this employment is associated with a return of approximately $\$ 3.4$ million in individual income taxes to the U.S. Treasury in 1994.

Additional jobs are indirectly supported by ERIP technologies, including employees of suppliers, subcontractors, and retailers. Additional tax revenues are associated with royalty payments on ERIP inventions, corporate income taxes, state and local sales and income taxes, and personal income taxes paid by indirect employment beneficiaries of the program.

Most ERIP technologies, including $58 \%$ of those without sales and $80 \%$ of those with sales, have acquired at least some financial support from external sources, after receipt of their ERIP grants. Consistent with the skewed distribution of sales and jobs, a small number of technologies are responsible for the great majority of the external funding. Qualitative information indicates that ERIP assistance played a critical role in helping some number of these technologies surmount early developmental barriers and ultimately reach a stage in which subsequent fund raising could be based on business performance.

Finally, this evaluation assessed the energy and environmental benefits associated with ERIP technologies.

- 116 trillion Btu's of energy and \$334 million of energy expenditures were saved in 1994 as a result of the commercial success of five ERIP technologies.

- These energy savings have resulted in reduced emissions of 2.1 million metric tons of carbon in 1994 alone.

The energy saved by these five ERIP technologies is enough to meet the United States' energy requirements for 12 hours. The reduction in greenhouse gas emissions is equivalent to removing 2.3 million cars from U.S. roadways. 
Table E.1 presents some of the indicators of program impacts that are discussed in the report. They point to noteworthy economic, energy, and environmental accomplishments as ERIP continues to enhance its services to inventors.

Table. E.1. Indicators of Program Impacts

\begin{tabular}{|c|c|}
\hline Category of Benefit & Indicator of Program Impact \\
\hline Market Entries & $\begin{array}{l}\text { - At least } 144 \text { ERIP technologies commercialized, representing a } \\
24 \% \text { commercialization rate. }\end{array}$ \\
\hline Sales & $\begin{array}{l}\text { - \$961 million (in } 1994 \text { dollars) of sales generated by these } 144 \\
\text { technologies through } 1994 .\end{array}$ \\
\hline Royalifies & $\begin{array}{l}\text { - \$28.2 million (in } 1994 \text { dollars) of royalties for licensed sales of } \\
\text { ERIP technologies through } 1994 \text {. }\end{array}$ \\
\hline Spinoffs & $\begin{array}{l}\text { - An additional } \$ 88 \text { million (in } 1994 \text { dollars) in sales generated by } \\
52 \text { spinoff technologies. }\end{array}$ \\
\hline Employment & $\begin{array}{l}\text { - } 757 \text { job-years directly supported by ERIP technologies in } 1994 \\
\text { and 6,646 supported in 10-year period, 1985-1994. }\end{array}$ \\
\hline Taxes & $\begin{array}{l}\text { - } 33.4 \text { million in ERIP-related income tax revenues returned to the } \\
\text { U.S. Treasury in } 1994 \text {. }\end{array}$ \\
\hline Leveraging & $\begin{array}{l}\text { - } 58 \% \text { of inventors without sales and } 80 \% \text { of those with sales have } \\
\text { acquired at least some additional financial support following } \\
\text { receipt of their ERIP grant. }\end{array}$ \\
\hline Energy Savings & $\begin{array}{l}\text { - } \$ 334 \text { million (in } 1994 \text { dollars) of energy expenditures saved in } \\
1994 \text { by five ERIP technologies. }\end{array}$ \\
\hline Environmental Benefits. & $\begin{array}{l}\text { - Carbon emissions reduced by } 2.1 \text { million metric tons in } 1994 \text {, as } \\
\text { the result of five ERIP technologies. }\end{array}$ \\
\hline
\end{tabular}


CPW Commercialization Planning Workshops

DOE Department of Energy

EC European Community

ERIP Energy-Related Inventions Program

FTE Full-time equivalent employees

GNP Gross National Product

GRI Gas Research Institute

NBS National Bureau of Standards

NIST National Institute of Standards and Technology

R\&D Research and Development

SBA Small Business Administration

SBIR Small Business Innovation Research 


\section{GLOSSARY $^{1}$}

Alternative market application: occurs when the results of an $R \& D$ project are subsequently applied to a market or use that differs from the originally intended application.

Base technology: the components of a core technology that are commonly available in the marketplace.

Core technologies: the discrete, unique skills and techniques that embody a technology.

Corporation: firm granted a state charter to incorporate, thereby limiting the liability of its owner(s).

Debt capital: business financing that normally requires periodic interest payments and repayment of the principal within a specified time.

Equity capital: an investment in exchange for partial business ownership. The inventor's financial return comes from dividend payments and from growth in the net worth of a business.

External validity: refers to the ability of the sample-based results to be extrapolated to one or more larger populations. Is the sample representative, and can results be extrapolated to other participants, or to next year's participants?

Key technology: the components of a core technology that provide the technology with its competitive edge and differentiate it from what is currently in the marketplace.

Informal capital: financing from an informal, unorganized source; includes informal debt capital such as trade credit or loans from friends and relatives and informal equity capital from informal investors.

Innovation: introduction of a new idea into the marketplace in the form of a new product or service or an improvement in organization or process.

Internal validity: refers to the validity of the estimated program impacts for the sample selected. Are the impacts attributable to the program, and can alternative explanations be ruled out?

Partnership: two or more parties who enter into a legal relationship to conduct business for profit. Defined by the Internal Revenue Code as joint ventures, syndicates, groups, pools, and other associations of two or more persons organized for profit that are not specifically classified in the IRS code as corporations or proprietorships.

Proprietorship: the most common legal form of business ownership; about 85 percent of all small businesses are proprietorships. The liability of the owner is unlimited in this form of ownership.

\footnotetext{
${ }^{1}$ Many of the following definitions of terms are reproduced from the glossary published in the U.S. Small Business Administration, 1993.
} 
Public offering: a general solicitation for participation in an investment opportunity. Interstate public offerings are supervised by the Securities and Exchange Commission.

Second-generation technologies: occur when the technology that was the subject of an R\&D project is significantly altered and enhanced through subsequent R\&D.

Small business: a business smaller than a given size as measured by its employment, business receipts, or business assets. The SBA generally uses employment data as a basis for size comparisons, with small firms defined as having fewer than 100 or fewer than 500 employees.

Small Business Investment Company: privately owned company licensed and funded through the SBA and private sector sources to provide equity or debt capital to small businesses.

Sole proprietorship: unincorporated, one-owner business, farm, or professional practice.

Spinoff: any technology development or market application that occurred as the result of the ERIP project and was not the technology or market that the original project addressed.

Standard Industrial Classification (SIC) codes: a classification system established by the federal government that is used to categorize businesses by type of economic activity.

Subcontract: - contract between a prime contractor and a subcontractor or between subcontractors to furnish supplied or services for performance of a prime contract or a subcontract. 


\section{INTRODUCTION}

Technological innovation is essential to the future well-being of the United States. The ability of the nation to sustain economic growth, increase its standard of living, protect the environment, and improve its energy security depends on its success in developing and commercializing new products, processes, and services. Technological progress has been shown to be the single most important determinant of economic and productivity growth (Tassey, 1995; U.S. Department of Energy, 1995a). When applied to the development and improvement of energy technologies, technical progress also often contributes to important secondary benefits related to pollution prevention and national security.

Small businesses have been particularly successful in producing innovations for the marketplace (The Futures Group, 1984) and are seen as key players in employment and economic growth (Birley, 1987). Firms with less than 500 employees dominate job creation: the vast majority of new companies are small, and most of the jobs derived from business expansions occur within small businesses (Kirchhoff and Phillips, 1988). Yet, small businesses and independent inventors face numerous barriers that impede their ability to convert creative ideas into marketable products with commercial value. Successful commercialization requires the ability to:

- finance new technology ventures;

- hire and train skilled scientists, engineers, managers, and production workers;

- protect innovations from imitators;

- acquire or access complementary skills and technologies required to make an innovation useful; and

- gain market acceptance (U.S. Congress, Office of Technology Assessment, 1995, p. 22).

Small businesses and independent inventors face unique barriers in all of these areas.

Over the past 15 years, numerous federal and state programs have been created to spur the development of technology-based new companies by providing commercialization assistance. The EnergyRelated Inventions Program (ERIP) is one of the first programs to offer commercialization assistance to small businesses and independent inventors, and its continuous operation since 1974 makes it one of the most longstanding commercialization assistance programs in the United States. The performance of ERIP is the subject of this report. 


\subsection{GOALS OF THE EVALUATION}

Since the inception of the ERIP, the U.S. Department of Energy (DOE) has systematically monitored the progress of the inventions it has supported. Case studies of ERIP inventions have been completed (Rorke and Livesay, 1986), and the economic, energy, and environmental impacts of the Program have been quantified (Brown, et al., 1994). Past evaluations also have examined characteristics of the technologies, inventors, markets, and business strategies that have contributed to commercial success. This report presents the results of the 1995 evaluation of the Energy-Related Inventions Program. This is the sixth such evaluation based on surveys of ERIP inventors and contacts, and the results of the 1995 survey indicate the continuing benefits of the Program for grant recipients and the public at large.

The evaluation was undertaken primarily to obtain up-to-date information on the progress of ERIPsupported inventions. In addition, the evaluation seeks to answer a wide array of questions relevant to the mission and operation of the Program, such as:

- What difficulties have ERIP inventors encountered in their quest to commercialize their inventions?

- How successful has licensing been as a strategy for commercializing ERIP's technologies?

- How much does it cost for ERIP inventors to commercialize their technologies, and which sources of funding provide the greatest financial support?

- Which types of ERIP assistance are valued most by program participants?

These and many more questions are addressed within this report.

\subsection{OVERVIEW OF THE PROGRAM}

Established in 1974 under the Federal Nonnuclear Energy Research and Development Act (P.L. 93577), ERIP is directed to assist the development of nonnuclear energy-related inventions with outstanding potential for saving or producing energy, "particularly those submitted by individual inventors and small companies." The goal is to help individual and small company inventors with promising technologies develop their inventions to a stage of development that would attract the investment necessary for private sector commercialization. Many of these technologies face significant market and industry barriers that reduce their ability to attract early funding and intensify the difficulties of product development. Individual and small business inventors often lack the business experience needed to surmount these hurdles.

Anyone can submit an invention at any stage of development to the program for a free, confidential evaluation. The legislation provides for the National Institute of Standards and Technology (NIST), 
previously called the National Bureau of Standards (NBS), to evaluate the inventions submitted, assessing them for technical feasibility, energy conservation or supply potential, and commercial possibilities. Only $2 \%$ of the inventions pass through the screening process and are recommended to DOE for technical and financial support.

DOE grants are provided to most of these recommendees to pay for technical research, prototype development, testing, and a variety of other activities that help move the technologies one step closer to the market. In addition, ERIP conducts Commercialization Planning Workshops for inventors in the program. These Workshops were initiated in 1984, when it became clear from previous program evaluations that many inventors were failing in the marketplace because of their lack of business acumen. To find inventors and encourage innovation, ERIP holds several National Innovation Workshops each year in different regions of the country, jointly sponsored by local businesses, inventor organizations, and universities.

Since the Program's 1974 beginning, more than 31,000 inventions have been submitted to NIST for evaluation, and more than 625 of these have been recommended to DOE for support. Seventy-eight percent of these recommendees have received DOE grants averaging $\$ 78,000$ (in current dollars). Approximately half of the program's funding is spent by NIST to conduct the technical evaluation of applications to the program, $15 \%$ is for DOE's program office (to support the Workshops, technical assistance, grant processing, and program evaluation), and $35 \%$ goes toward new grants. These proportions can vary from year-to-year depending upon program needs.

\subsection{MEASURES OF PROGRAM SUCCESS}

A program such as ERIP has an impact on diverse stakeholder groups (including independent inventors, the business community, policy makers, and taxpayers), each of which evaluates the program's success in different ways. Inventors want to know the benefits of program participation in terms of technical assistance, commercialization planning, and help with the subsequent acquisition of funding. The business community might want to know about the relationship between the program and the creation of viable businesses, and would likely evaluate the technologies in terms of profit margins, sales levels, return-oninvestment, or comparative advantage. Policy makers are concerned about whether the program meets its objectives of conserving or producing energy, the creation of new businesses and employment, and the development of promising new energy technologies. Taxpayers are most concerned about the relationship between program costs and the extent to which these costs are counterbalanced by economic returns and other benefits to the nation. This evaluation attempts to address at least some of the concerns of all of these stakeholder groups. 


\subsection{OVERVIEW OF THE REPORT}

This report begins by describing the evaluation design employed here, including the sampling strategy and collection of data (Chapter 2). Results are presented in the remaining chapters. Chapter 3 focuses on the market status of ERIP inventions and estimates of invention sales. Chapter 4 documents the commercial impact of the inventions and products that spin off from the technology, market, and business developments supported by the Program. Chapter 5 examines the employment and tax revenues associated with the inventions supported by the program. Attention then turns to the funds raised by program participants as an indicator of the program's ability to leverage its resources (Chapter 6). The energy and environmental impacts of ERIP supported inventions are described in Chapter 7. The report ends with an analysis of participant ratings of Program assistance and a brief discussion of its findings (Chapter 8 ).

Along with presenting current statistics for the Program and its technologies, previous research is reviewed and findings from evaluations of other programs are compared with the results for ERIP. In addition, a special effort is made to compare and contrast the commercial success of different cohorts of ERIP technologies over different time periods in order to assess longitudinal aspects of the Program and the technologies it has supported. 


\section{EVALUATION DESIGN}

\subsection{SAMPLING STRATEGY}

In the 17 fiscal years between October 1, 1976, and September 30, 1993, a total of 609 inventions were recommended to DOE's Energy-Related Inventions Program by the National Institute of Standards and Technology. These inventions are the technologies of interest to this evaluation. The previous ERIP evaluation (Brown, et al., 1994) examined the subset of 557 of these inventions that had been recommended to NIST prior to October 1,1991 . This previous evaluation concluded that data could no longer be obtained for 159 ERIP inventions due to the deaths of some inventors, insufficient addresses, and refusals to participate in the survey process.

For the 1995 evaluation, a survey was mailed to the remaining 450 ERIP inventors. Of these 450 inventors, 98 were considered "promising" in terms of the likelihood that they had experienced sales of their ERIP technology since the last evaluation. This sample of "promising" inventions was identified from the results of past ORNL evaluations and by the Program's DOE invention coordinators. A targeted effort to contact this sample maximized the inclusion of the most successful inventions in the impact evaluation.

Data collection was initiated during the summer of 1995 by mailing a 14-page questionnaire to 450 ERIP participants. A copy of the questionnaire is reproduced in Appendix A. The questionnaire was divided into sections that dealt with:

- technology description

- contact and inventor information

- development time line

- energy and environmental benefits

- sales data and licensing revenues

- employment
- sources of funding

- spinoff technologies

- difficulties of commercialization

- ratings of types of ERIP assistance

- additional comments

While most of these lines of inquiry have been pursued over several years as part of the ERIP evaluation effort, several of them represent either new treatments of issues considered years ago, or entirely new issues for the evaluation effort. The difficulty of commercialization is one example of a new issue for the impact evaluation.

Those 383 participants who had been interviewed during previous evaluations were sent a questionnaire that was completed, as much as possible, from information in the existing ORNL database. The 67 participants who had not been included in any of the previous impact evaluations or had not responded to previous evaluations were mailed a questionnaire that was blank except for the information on the contact, inventor, and a technology description obtained from DOE and NIST files. Thus, all of the 
questionnaires covered the same topics, but they differed in terms of the amount and types of data that they contained when mailed to each participant. In addition to collecting new data, the mail survey offered an opportunity for previously interviewed ERIP participants to review the data collected from them during earlier evaluations.

After the one-month deadline for return of the mail survey, nonrespondents were mailed a second questionnaire. A national residential telephone directory on $\mathrm{CD} \mathrm{ROM}^{1}$ was used to locate approximately five of the many inventors who had moved since the Program last contacted them.

Table 2.1. Summary of Survey Responses

\begin{tabular}{|c|c|c|c|c|}
\hline Samples of Inventors & $\begin{array}{l}\text { Respondents } \\
\text { to the Vhail } \\
\text { Survey }\end{array}$ & $\begin{array}{l}\text { Targeted } \\
\text { Eollow-up } \\
\text { of Non- } \\
\text { respondents }\end{array}$ & respondents & Total \\
\hline Promising Inventions & 40 & $40^{\mathrm{a}}$ & 18 & 98 \\
\hline Other Inventions & 131 & 0 & 221 & 352 \\
\hline Total & 171 & 40 & 239 & 450 \\
\hline
\end{tabular}

${ }^{\mathrm{a}} 4$ of these responded by mail as the result of a telephone follow-up.

Altogether 171 of the 450 participants returned their questionnaires by mail as a result of these two mailings. The response rate for the promising inventions ( 40 out of 98 or $41 \%$ ) was higher than the response rate for the other inventions (131 out of 352 or $37 \%$ ).

The 58 nonrespondents from among the promising inventions were targeted for follow-up telephone interviews. Forty were completed. The other 18 either could not be located or refused to participate in the surveying.

In total, data were collected in 1995 on 211 inventions, or $47 \%$ of the 450 ERIP inventions. Historic information from previous evaluations is also available for 253 additional inventions, and this information is used in various analyses throughout this report. To illustrate, an inventor who reported sales during the 1985 evaluation would still be included in the cumulative count of inventions that have experienced sales, even if further information were not obtained in subsequent evaluations. Altogether, some evaluation data are available for a total of 464 of the 609 inventions.

A subset of the analyses presented in subsequent chapters of this report draws exclusively on information collected in 1995 for the sample of ERIP technologies. For instance, discussions of the status

${ }^{1}$ PhoneDisc (R) CD-ROM, Version 4.01, Software Copyright 1986-1995 Digital Directory Assistance, Inc. 
of inventions in 1994 are based on this limited sample. Analyses that are cumulative in nature, on the other hand, capitalize on the full database of 464 technologies-211 from the 1995 sample and 253 from previous years of data collection. Thus, measures of cumulative sales and the employment impacts of ERIP technologies rely on this larger base of data.

\subsection{INTERNAL AND EXTERNAL VALIDITY OF THE EVALUATION}

Program evaluations are often judged in terms of their internal and external validity (Campbell and Stanley, 1971). Internal validity refers to the validity of the estimated program impacts for the sample selected. Are the impacts attributable to the program, and can alternative explanations be ruled out? External validity refers to the ability of the sample-based results to be extrapolated to one or more larger populations. Is the sample representative, and can results be extrapolated to other participants, or to next year's participants? Each of these types of validity is discussed below.

The evaluation design does not involve a control group in the strict meaning of the word against which the progress of ERIP inventions can be compared. Rather, the literature at large is relied upon for insight into the invention and innovation process as it occurs without government intervention. In addition, in 1994, a test for internal validity was conducted that compared ERIP technologies to a sample of 79 inventions labeled "program referrals" (Brown, Curlee, and Elliott, 1995). The results indicated significant differences in terms of several indicators of commercial success. These findings supported the supposition that ERIP technologies enjoy greater success than program referrals, and that ERIP technologies achieved their considerable commercial success at least in part because of the support provided by the Program. Thus, the evaluation design passed this test of internal validity.

No analysis of external validity was conducted in this 1995 evaluation. In the previous evaluation (Brown, et al., 1994), however, an analysis of nonresponse bias was completed as a partial test of internal validity. In particular, a sample of 11 nonrespondents was interviewed to determine whether or not it was feasible to generalize from responding participants to the entire population of participants. It was found that the sample of 11 nonrespondents was similar to the "other" inventors (i.e., those that were not flagged as "promising") in terms of the stage of development of their technologies and the incidence of sales and licensing. However, they were markedly different in terms of activity status: none of the 11 nonrespondents were actively pursuing the development of their ERIP technologies when interviewed in 1993 (compared to $63 \%$ of the other inventors). Thus, it was concluded that generalizations from respondents were justifiable only for indicators that measure progress to date, and not on measures of current activity or likely future progress. 
Thus, as is true of most innovation program evaluations (Roessner, 1989), a precise assessment of the net benefits of the Energy-Related Inventions Program is beyond the reach of this evaluation. The approximate benefits identified in the evaluation, however, are considered to be credible. Further, the fact that six quantitative evaluations of ERIP conducted over the past decade have produced similar indicators of commercial progress, supports the view that the evaluation designs have been robust (Brown, et al., 1987; Brown and Snell, 1988; Brown and Wilson, 1990; Brown, Wilson and Franchuk, 1991; Brown, et al., 1994). 


\section{COMMERCIAL PROGRESS OF ERIP INVENTIONS}

Each year new ERIP technologies are introduced into the market, while others are withdrawn. New licensing agreements are signed, while others expire or are terminated. Many ERIP inventions progress steadily through sequential stages of development, some fail and are shelved, while others cycle through repeated stages of technical development in response to market and user feedback. This cyclical nature of technological development and commercial success is clearly evident in the series of evaluations that have been completed during the life of the program. From year-to-year, there has been considerable turnover in the make-up of the subset of ERIP technologies that account for the bulk of commercial sales. Yet the number of ERIP technologies in the market in any one year, and the sales attributable to these technologies, have remained surprisingly stable.

This chapter assesses the commercial progress of ERIP inventions. It begins by describing the current status of these inventions in terms of level of activity and stage of development. The chapter then documents the number of ERIP technologies that have been in the market (i.e., generating sales) during various years since 1980. This assessment draws on the full database of information on 609 ERIP technologies. The chapter further extends this analysis of commercialized inventions to assess the length of time technologies have remained in the market. Attention then turns to assessing the performance of ERIP based on the total sales of ERIP technologies relative to the program's appropriations and grants. This section is followed by a description of royalties from licensed ERIP technologies. The chapter ends with data on inventors' difficulties in commercializing their technologies.

\subsection{CURRENT STATUS OF ERIP INVENTIONS}

Analysis of the status of ERIP technologies through 1994 indicates that a large majority $(93 \%)$ of the inventions in the promising sample ${ }^{1}$ were either actively being developed or were being pursued at a low level of effort (Table 3.1). These results suggest an increase in level of activity compared to 1992, when $81 \%$ of the promising sample of inventions were under development at either an active or low level of effort (Brown, et al., 1994). This trend is reinforced by the results for "other" inventions. As of the end of 1994,

\footnotetext{
${ }^{1}$ The promising sample comprises inventions that are judged by key informants or past research as being the most likely to enter the market and experience commercial success.
} 
Table 3.1. Activity Status of ERIP Projects in 1994

\begin{tabular}{|c|c|c|c|c|}
\hline \multirow{2}{*}{ Activity Category } & \multicolumn{2}{|c|}{ Promising Inventions ${ }^{\mathrm{a}}$} & \multicolumn{2}{|c|}{$\begin{array}{l}\text { Other Inventions } \\
(\mathrm{N}=90)\end{array}$} \\
\hline & $\begin{array}{l}\text { Mamber of } \\
\text { Hoventions }\end{array}$ & Percent & $\begin{array}{l}\text { Number of } \\
\text { Inventions }\end{array}$ & Percent \\
\hline Active development began in 1994 & 0 & 0 & 1 & 1 \\
\hline Active & 61 & 85 & 52 & 57 \\
\hline low level of effort & 6 & 8 & 13 & 14 \\
\hline Suspended temporarily & 2 & 3 & 14 & 15 \\
\hline Suspended indefinitely & 2 & 3 & 6 & 7 \\
\hline Falled & 1 & 1 & 3 & 3 \\
\hline Chapter I IReorganization & 0 & 0 & 0 & 0 \\
\hline Ghapter T/Bankrupt & 0 & 0 & 0 & 0 \\
\hline Sold Patent Rights & 0 & 0 & 3 & 3 \\
\hline Sum of Received Cases & 72 & 100 & 90 & 100 \\
\hline
\end{tabular}

${ }^{2}$ Those inventions judged by key information or past research as being the most likely to enter the market and experience commercial success.

$71 \%$ of the sample of "other" inventions were under either an active or low level of development, while at the end of 1992 , only $63 \%$ of the "other" inventions were under either an active or low level of development. ${ }^{2}$

Analysis of the stage of development in Table 3.2 indicates that few ERIP technologies were in the concept definition and development or working model stages in 1994 (0\% of the promising inventions and $25 \%$ of the other inventions). Over one-third (38\%) of the other inventors were undergoing prototype development, testing, and engineering design, which was their most frequent stage of development. This was also the modal stage for the other inventions in $1992^{3}$. An impressive $83 \%$ of the promising inventions were in limited or full production and marketing in 1994. A far smaller percentage (54\%) characterized the sample of promising inventions as of 1992 . In 1994, 16\% of the other inventions were in limited or full production and marketing, which is virtually the same as the $17 \%$ rate in 1992 and somewhat less than the $25 \%$ rate in 1990. The 56 promising inventions and 10 other inventions that had reached limited or full production and marketing by 1994, based on Table 3.2, are only a subset of the population of ERIP inventions that have

\footnotetext{
${ }^{2}$ However, this pattern could reflect the fact that there are more nonrespondents in 1995 compared to 1993 , and nonrespondents tend to be less active in the development of their ERIP technologies.

${ }^{3}$ This difference may simply reflect the fact that the promising inventors defined for surveying emphasis in 1994 (N=98, see Table 2.1) was smaller and more selective than in 1992 ( $N=133$, See Table 2.1 in Brown, et al., 1994).
} 
Table 3.2. Stage of Development of ERIP Projects in 1994

\begin{tabular}{|c|c|c|c|c|}
\hline \multirow{2}{*}{ Development Category. } & \multicolumn{2}{|c|}{ Promising Inventions: } & \multicolumn{2}{|c|}{ Other Inventions } \\
\hline & $\begin{array}{l}\text { Number of } \\
\text { Inventions }\end{array}$ & Percent & $\begin{array}{l}\text { Number of } \\
\text { Inventions }\end{array}$ & Percent \\
\hline Concept definition and development & 0 & 0 & 4 & 7 \\
\hline Working nodel & 0 & 0 & 11 & 18 \\
\hline $\begin{array}{l}\text { Prototype development, testing, } \\
\text { engineering design }\end{array}$ & 3 & 4 & 23 & 38 \\
\hline Pre production prototype testing & 2 & 3 & 7 & 11 \\
\hline Production prototype & 7 & 10 & 5 & 8 \\
\hline Limited production and marketing & 25 & 37 & 8 & 13 \\
\hline Full production and marketing & 31 & 46 & 2 & 3 \\
\hline ProductObsolescence & 0 & 0 & 1 & 2 \\
\hline Sum of Received Cases: & 68 & 100 & 61 & 100 \\
\hline
\end{tabular}

entered the market and experienced sales. This is because only a subset of the ERIP inventions with documented sales based on previous ORNL evaluations participated in the 1995 survey.

\subsection{NUMBER OF ERIP INVENTIONS WITH SALES}

Significant commercial progress has been made by ERIP inventions during each of the most recent evaluation periods. By the end of 1994, 144 ERIP inventions are known to have achieved sales. This represents $24 \%$ of the population of 609 ERIP technologies, which is similar to the estimate of $23 \%$ provided by the 1993 evaluation. Both figures are probably underestimates of the true percentage, since we were unable to collect information on all of the technologies.

The $24 \%$ success rate is higher than the success rates of technological innovations as a whole, based on a review of the literature. The widely cited Booz-Allen \& Hamilton study (1982), for instance, reported that despite considerable investments in up-front stages of exploration, screening, and business analysis, it takes seven new product efforts to get one product to market-that is, only $14 \%$ of new products are successfully introduced. This suggests that ERIP inventions are at least as successful as technological innovations generally, though meaningful comparisons are difficult to make because of differences in products, technologies, and measures of success. The literature has reported success rates ranging from $1 \%$ to $85 \%$ (Cooper, 1983; Crawford, 1987). 
Another way to quantify commercial success is by comparing the number of ERIP technologies that have experienced sales to the cost of the Program. From 1978 through 1994, ERIP expended \$82 million (in current dollars). At least 144 of the technologies it has supported have entered the market. Similar statistics are available for (1) the Gas Research Institute (GRI), which has operated an R\&D program since 1978, and (2) the European Community (EC), which has operated a promotion and exploitation program since 1968 (Chemistry and Engineering News, July 8, 1991). By early 1991, 111 new or improved products, processes and techniques had been sold or were in commercial service, due to GRI's R\&D budget of $\$ 1.41$ billion (Dombrowski, et al., 1991). By 1990, approximately 50 inventions supported by the EC had been put on the market as the result of several billion dollars of R\&D funding. ERIP's accomplishments compare favorably with both of these other programs.

\subsubsection{Market Entries and Exits}

The market entries and exits of ERIP inventions over the past 15 years are portrayed in Fig. 3.1. A market entry in a particular year is an invention that had sales that year, but not the previous year. A market exit occurs when an invention did not have sales in the year in question, but did have sales in the previous year. Inventions "in the market" had sales during the year in question, as well as during the previous year.

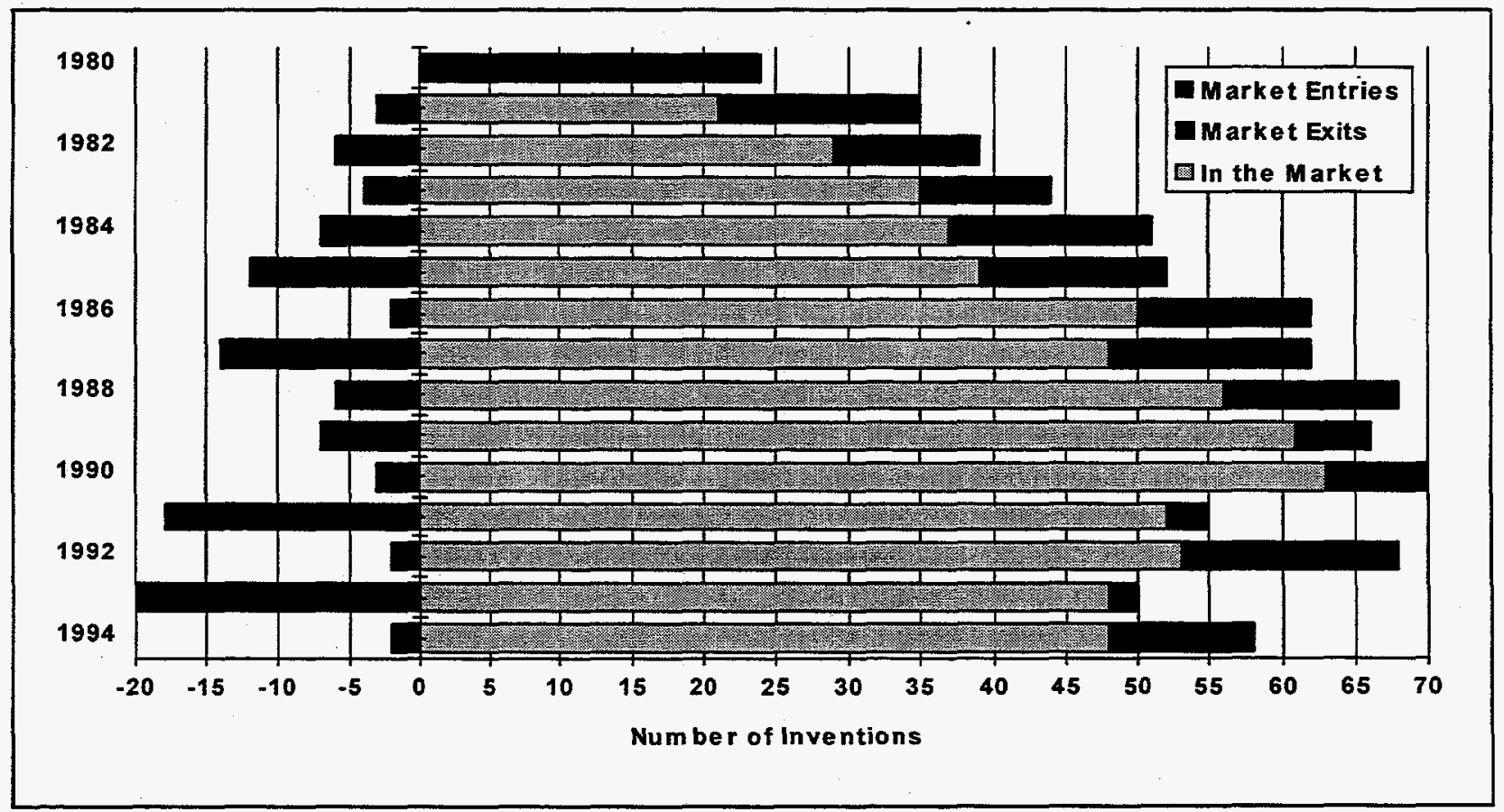

Fig. 3.1. ERIP inventions entering, in, and exiting the market, by year. 
The number of ERIP technologies in the market more than doubled from 1980 to 1984, with market entries in most years outnumbering market exits by a wide margin. Between 1984 and 1994, the numbers of ERIP technologies in the market have fluctuated between 50 and 70 . Compared to other years during this ten-year period, 1985, 1987, 1991 and 1993 had large numbers of market exits. These years along with 1989 are also the years where exits outnumbered entries. Many of the market exits in these alternating "odd" years are due to missing sales data rather than an absence of sales: whenever we survey an inventor we typically have collected the most recent two years of data ending in an even year.

Based on anecdotal and case study evidence, the relatively low energy prices that typified the second half of this period have had an adverse effect on a subset of ERIP technologies. Some of the market exits during this period were technologies whose market acceptance was tightly linked to energy prices. Unfortunately for them, between 1984 and 1994, crude oil prices (for domestic first purchase) plummeted from nearly $\$ 39$ per barrel to $\$ 22$, coal prices dropped from $\$ 28$ to $\$ 10$ per short ton, natural gas prices decreased from $\$ 2.9$ to $\$ 1.5$ per 1,000 cubic foot, and electricity prices declined from $6.9 \notin$ to $5.5 \notin$ per kWh-all in 1987-\$ (Energy Information Administration, 1995a, pages 171, 201, 223, 249). In addition to contributing to market exits, this decline in real energy prices has hindered the acquisition of development funds needed to introduce many ERIP technologies into the marketplace. In the early 1990 's, several market exits also were directly brought about by the nation's recession.

Just as an entry into the market does not ensure continued success, not all exits are permanent. Indeed, ERIP offers several examples of technologies that were withdrawn, redesigned based on initial market feedback, and then reintroduced. Such a pattern is unusual, however. Most of the 144 ERIP inventions with sales have sustained product life cycles. Of the 93 inventions that entered the market before 1987 , at least 47 were still in the market by the end of 1990 , and at least 30 were still in the market by the end of 1994 (Appendix B). ${ }^{4}$ These product longevity rates are consistent with Crawford's (1987) observation, based on a review of the literature, that around $65 \%$ of new products remain in the market for more than a few years.

\subsubsection{Market Entries Over Time}

Typically, it takes many years for inventions to become market-ready. As a result, one would expect low rates of commercialization among inventors who have only recently applied to ERIP and been recommended to DOE by NIST for support. On the other hand, as the Energy-Related Inventions Program

\footnotetext{
${ }^{4}$ It is not possible to provide precise numbers of inventions because some of the technologies with sales prior to 1987 did not participate in subsequent ERIP evaluation surveys. Thus, our information is incomplete.
} 
has gained experience in identifying and supporting worthwhile inventions, one might expect an increasing percentage of ERIP awardees to succeed in reaching the marketplace assuming all other major factors were constant such as quality of applicants, strength of the overall economy, energy prices, etc.

Table 3.3 indicates commercialization totals and rates for two-year ERIP cohorts based on date of DOE's receipt of NIST's recommendation for funding. With the exception of the low success rate of the initial cohort, the earlier periods generally experienced a higher rate of commercialization than the later periods. If the 609 technologies are divided into two nearly equal cohorts - pre- and post-September 1985 - the commercialization success rate is significantly higher for the earlier cohort (29\%) than for the more recent cohort (18\%). The more recent cohort is also experiencing virtually all of the ERIP increase in the number of inventions with sales. Thus, this difference in success rates across cohorts is likely to lessen over time, as more of the recent inventions are successfully launched.

Table 3.3. Number of ERIP Technologies with Sales by Date of DOE Receipt

\begin{tabular}{|c|c|c|c|c|c|}
\hline Numbers & $\begin{array}{l}\text { Namber } \\
\text { of Cases }\end{array}$ & $\begin{array}{l}\text { Date Received by } \\
\text { DOE, by Fiscal }\end{array}$ & $\begin{array}{l}\text { Number of } \\
\text { Grventions with } \\
\text { Sales Through } \\
1994\end{array}$ & $\begin{array}{l}\text { Percent of } \\
\text { Inventions } \\
\text { with Sales } \\
\text { Through } \\
1994\end{array}$ & $\begin{array}{c}\text { Percent } \\
\text { Increase } \\
\text { (1992 to 1994) }\end{array}$ \\
\hline $1-46$ & 43 & Feb 76-Sept 77 & 7 & $18 \%$ & 0 \\
\hline $\begin{array}{l}43,44, \\
47-119\end{array}$ & 75 & Oct 77 -Sept 79 & 22 & $29 \%$ & 0 \\
\hline $\begin{array}{c}34,120- \\
189\end{array}$ & 70 & Oct 79-Sept 81 & 30 & $40 \%$ & 0 \\
\hline $190-245$ & 56 & Oct $81-$ Sept 83 & 14 & $25 \%$ & 0 \\
\hline $246-325$ & 80 & Oct 83-Sept 85 & 20 & $25 \%$ & 5 \\
\hline $326-409$ & 84 & Oct 85 -Sept 87 & 19 & $23 \%$ & 12 \\
\hline $410-527$ & 79 & Oct $87-$ Sept 89 & 16 & $20 \%$ & 45 \\
\hline $487-557$ & 69 & Oct 89-Sept 91 & 13 & $19 \%$ & 18 \\
\hline $558-609$ & 52 & Oct $91-$ Sept 93 & 3 & $6 \%$ & N/A \\
\hline
\end{tabular}




\subsubsection{Market Entries by Mode of Commercialization}

Three different modes of commercialization have been used by ERIP inventors to achieve sales:

- inventors have used their existing company (or their small business employer) as the business infrastructure for developing and marketing their technology (i.e., "existing companies");

- inventors have created new business ventures to launch their ERIP technologies (i.e., "new ventures"); and

- inventors have licensed or sold their ERIP technologies as a means of bringing their technologies to market (i.e., "licensing").

Inventors typically retain an instrumental role in the innovation process with either of the first two strategies. This is not usually the case when the technology is licensed or sold by the inventor.

Between 1980 and 1994, 60 inventions (or $42 \%$ of the 144 that had achieved sales) were manufactured and marketed by the inventor's existing company (Fig. 3.2). A smaller number, 53 inventions, or $37 \%$, were commercialized by a new venture. Lastly, 52 inventions (36\%) were commercialized entirely or in part through licensing. These percentages sum to $115 \%$ because 21 technologies have been commercialized via licensing agreements and sales through the inventors' existing companies $(N=10)$ or new ventures $(\mathrm{N}=11)$.

Since 1988, the percentage of inventions marketed by existing companies has remained stable. Inventions marketed by new ventures declined somewhat since 1992, reversing an upward trend since 1988. Licensing increased its percentage since 1992, when it was a mode of commercializing $30 \%$ of the ERIP technologies with sales, reversing a slight downward trend in the successful use of licensing since 1988.

\subsection{SALES OF ERIP TECHNOLOGIES}

It is estimated that the total cumulative sales of ERIP technologies from 1980 through 1994 is $\$ 774$ million in current year dollars (Table 3.4); this translates to nearly one billion (i.e., $\$ 961$ million) of cumulative sales in 1994 dollars. The impressiveness of this number is underscored when it is compared to the sales performance of the Small Business Innovation Research (SBIR) Program, a much larger federal commercialization assistance program. Between 1983 and 1993, 11 federal agencies gave nearly 25,000 SBIR awards worth over $\$ 3.2$ billion to more than 50,000 firms. While many of these investments are still maturing, it is estimated that by 1992 , SBIR firms had received only $\$ 471$ million in sales (U.S. Congress, Office of Technology Assessment, 1995, p. 81).

ERIP sales show an almost steady rise from $\$ 20$ million in 1980 to $\$ 77$ million in 1989 with the exception of a $\$ 5$ million decline in 1984. A second sales decline in total sales of about $\$ 8$ million was 


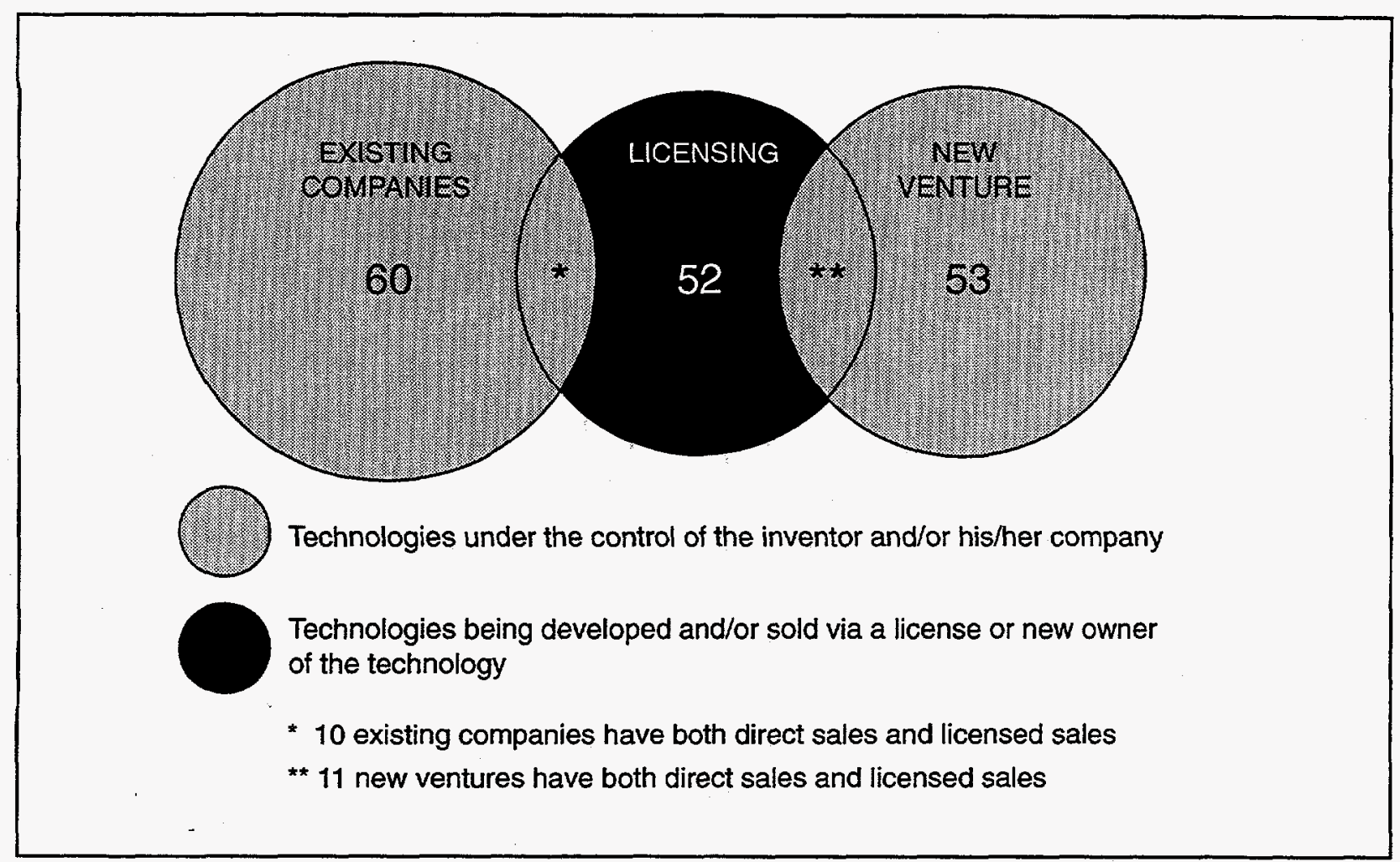

Fig. 3.2. Modes of commercialization used by 144 ERIP inventions.

experienced in 1990 , followed by a very substantial drop of $\$ 16$ million more in 1991 to $\$ 53$ million. The most recent three years have seen sales recover to $\$ 66$ million, $\$ 61$ million, and most recently, $\$ 71$ million. Thus, since 1986, when the sales of ERIP technologies reached $\$ 62$ million, the annual sales of ERIP technologies have fluctuated within a band ranging from $\$ 53$ million to $\$ 77$ million. Different mixes of technologies account for these sales each year, but the overall sales attributed to ERIP technologies have been relatively stable for the past nine years.

As is typical of new products and new technologies in general, there is great variation in the levels of sales generated by the ERIP technologies (Fig. 3.3). Cumulative sales of individual inventions range from less than $\$ 1,000$ to $\$ 132$ million through the end of 1994 . Sixty-nine (or almost half) of the inventions have had cumulative sales of less than $\$ 500,000$. The average cumulative sales of these 144 ERIP technologies is $\$ 5.4$ million, which is much larger than the median $(\$ 737,000)$ due to the impact of a small number of highly successful technologies. Over the years, detailed case studies have been conducted of the program's most successful technologies, in order to ensure the validity of their sales and employment data, since they have such a strong influence on the program's performance metrics. 
Table 3.4. Grants, Program Appropriations, and Cumulative Reported Sales ${ }^{\mathrm{a}}$

\begin{tabular}{|c|c|c|c|c|c|c|}
\hline \multirow[t]{2}{*}{ Year. } & \multicolumn{2}{|c|}{ Cumulative ERUP Sales in } & \multicolumn{2}{|c|}{$\begin{array}{l}\text { Gumulative ERIP } \\
\text { Appropriations in } \\
\text { Milions }\end{array}$} & \multicolumn{2}{|c|}{ Cumulative ERIP Grants } \\
\hline & $\begin{array}{l}\text { Current } \\
\text { Dollars }\end{array}$ & Dollars. & $\begin{array}{l}\text { Current } \\
\text { Dollars }\end{array}$ & Dollars & $\begin{array}{l}\text { Current } \\
\text { Dollars }\end{array}$ & Dollars \\
\hline 1976 & 0 & 0 & 1.5 & 3.9 & 0 & 0 \\
\hline 1977 . & 0 & 0 & 4.3 & 10.7 & 0.6 & 1.5 \\
\hline 1978 & 0 & 0 & 7.6 & 18.2 & 1.5 & 3.5 \\
\hline 1979 & 0 & 0 & 11.6 & 26.4 & 2.9 & 6.4 \\
\hline 1980 & 19.9 & 35.8 & 18.0 & 37.9 & 6.2 & 12.3 \\
\hline 1981 & 45.7 & 77.9 & 23.8 & 47.4 & 8.7 & 16.4 \\
\hline 1982 & 74.9 & 122.8 & 29.0 & 55.4 & 10.7 & 19.5 \\
\hline 1983 & 113.0 & 179.5 & 31.0 & 58.4 & 10.7 & 19.5 \\
\hline 1984 & 146.4 & 227.1 & 34.0 & 62.7 & 12.1 & 21.5 \\
\hline 1985 & 180.4 & 273.9 & 38.9 & 69.4 & 14.0 & 24.1 \\
\hline 1986 & 242.5 & 357.9 & 43.7 & 75.9 & 17.1 & 28.3 \\
\hline 1987. & 306.6 & 441.6 & 48.7 & 82.4 & 19.3 & 31.2 \\
\hline 1988 & 377.5 & 530.4 & 53.6 & $88: 5$ & 20.1 & 32.2 \\
\hline 1989 & 454.2 & 622.1 & 58.4 & 94.2 & 22.9 & 35.5 \\
\hline 1990 & 523.4 & 700.6 & 63.1 & 99.5 & 25.7 & 38.7 \\
\hline 1991 . & 576.4 & 758.3 & 68.6 & 105.5 & 27.7 & 40.9 \\
\hline 1992 & 642.3 & 827.9 & 74.3 & 111.5 & 30.1 & 43.4 \\
\hline 1993. & 702.9 & 890.1 & 80.3 & 117.9 & 32.0 & 45.5 \\
\hline 1994 & 773.7 & 960.9 & 86.3 & 123.9 & 34.0 & 47.5 \\
\hline
\end{tabular}

${ }^{2}$ Based on 144 ERIP technologies with sales.

In comparison, consider the benefits from New York's Manufacturing Extension Program (MEP) (Nexus Associates, Inc., 1996). Between April 1993 and December 1994, New York State invested \$12.9 million in manufacturing assistance. This resulted in a value-added impact of $\$ 29$ to $\$ 108.7$ million. ERIP invested \$12.4 million in assistance to inventors during 1993 and 1994, and over that period the inventions it has supported have generated $\$ 133.0$ million in sales. Thus, the economic impact of ERIP compares favorably with that of the New York MEP. 


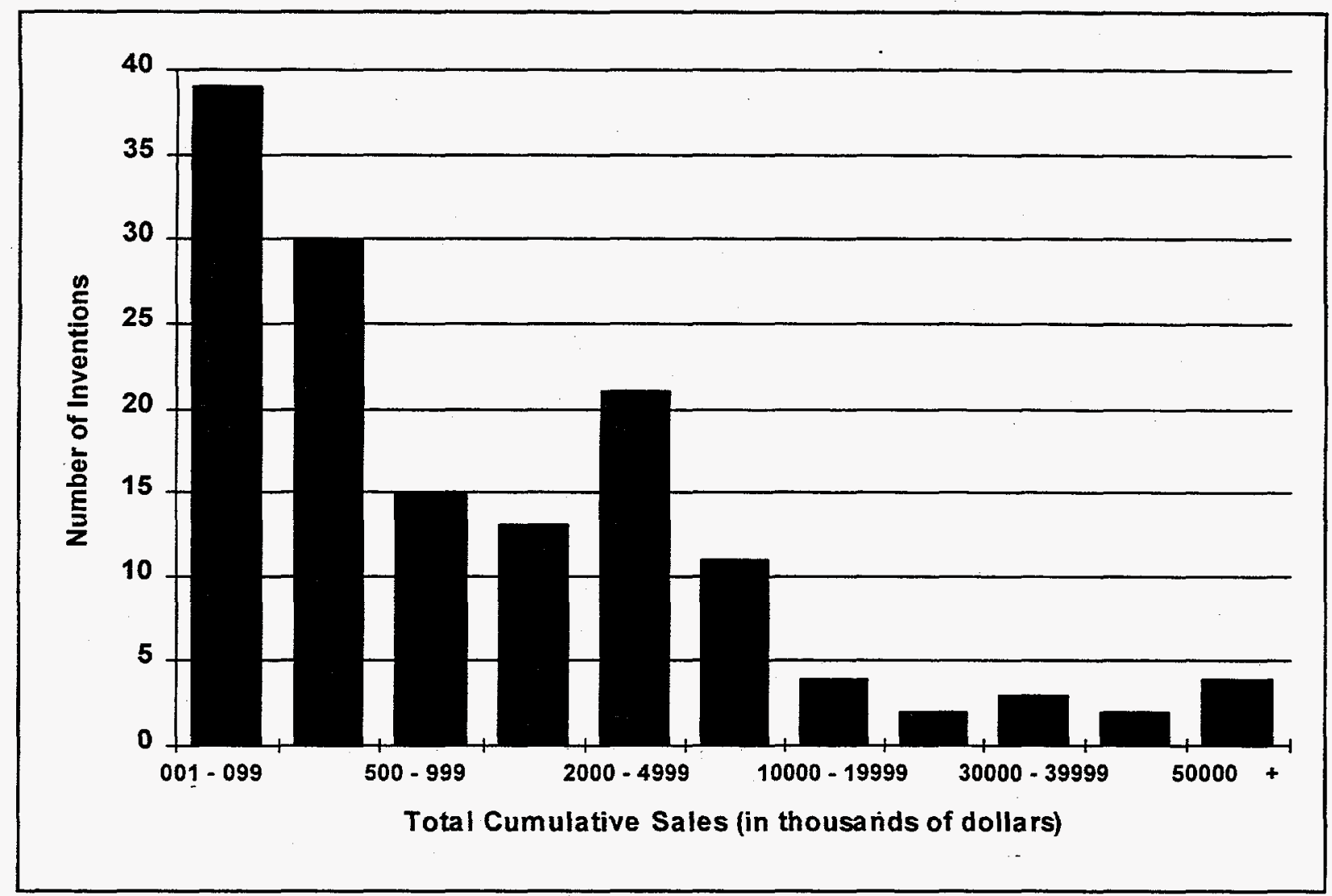

Fig. 3.3. Distribution of cumulative sales for ERIP technologies through 1994.

\subsubsection{Sales Over Time}

Table 3.3 showed that, in terms of numbers of technologies with sales, commercialization of the first half of ERIP technologies (through 9/30/85) was somewhat more successful than the second half of technologies. As Table 3.5 indicates, this success is even more pronounced in terms of the volume of sales: the first half of ERIP technologies have experienced cumulative sales of about $\$ 536$ million (in current dollars), whereas the more recent half of technologies reaching DOE have produced sales of $\$ 237$ million. This situation would appear understandable since the older technologies generally would have longer sales histories and higher sales than younger technologies. However, the fact that a single technology from the FY 85-87 cohort is responsible for approximately $\$ 133$ million in sales (accounting for a majority of the latter half's total sales) raises some concern about the commercialization success of these more recent ERIP technologies. 
Table 3.5. Sales of ERIP Technologies by Date of DOE Receipt (in millions of current year dollars)

\begin{tabular}{|c|c|c|c|c|c|}
\hline Numbers & $\begin{array}{l}\text { Number } \\
\text { of Cases }\end{array}$ & Dater Received by & $\begin{array}{l}\text { Sales } \\
\text { Through } \\
1994\end{array}$ & $\begin{array}{l}\text { Percent of } \\
\text { Total } \\
\text { Sales }\end{array}$ & $\begin{array}{l}\text { Percent } \\
(1992 \text { to } 1994)\end{array}$ \\
\hline $1-46$ & 43 & Feb 76-Sept 77 & 11.8 & 1.5 & - \\
\hline $\begin{array}{l}43,44, \\
47-119\end{array}$ & 75 & Oct 77-Sept 79 & 247.9 & 32.0 & 13.9 \\
\hline $\begin{array}{c}34,120- \\
189\end{array}$ & 70 & Oct 79-Sept 81 & 149.7 & 19.3 & 29.3 \\
\hline $190-245$ & 56 & Oct 81 -Sept 83 & 96.2 & 12.4 & 27.6 \\
\hline $246-325$ & 80 & Oct 83-Sept 85 & 30.5 & 3.9 & 23.0 \\
\hline $326-409$ & 84 & Oct 85 -Sept 87 & 173.6 & 22.4 & 13.5 \\
\hline $410-527$ & 79 & Oct $87-$ Sept 89 & 24.3 & 3.1 & 67.6 \\
\hline $487-557$ & 69 & Oct 89 -Sept 91 & 21.6 & 2.8 & 94.6 \\
\hline $558-609$ & 52 & Oct $91-$ Sept 93 & 17.7 & 2.3 & N/A \\
\hline
\end{tabular}

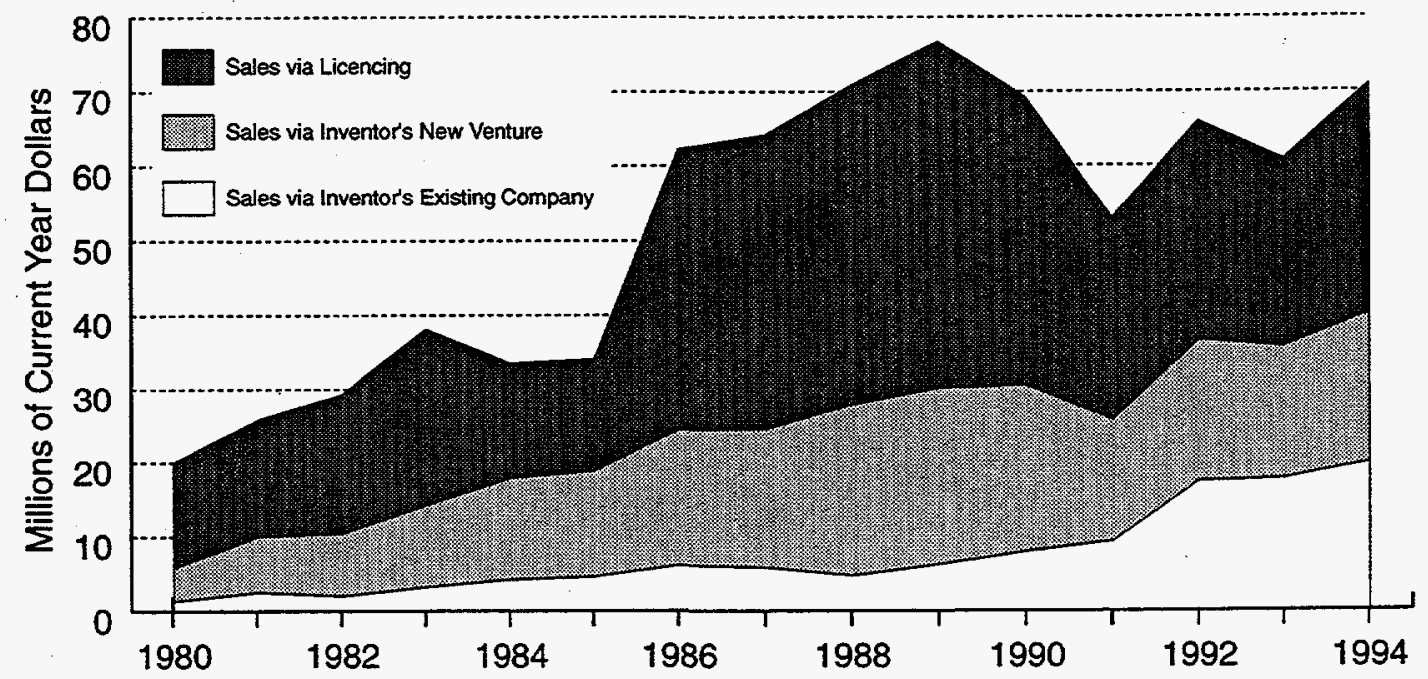

Fig. 3.4. Sales by licensing, new venture and existing company. 


\subsubsection{Sales by Mode of Commercialization}

In aggregate, licensed ERIP technologies have generated more sales than the combined sales of inventions marketed directly by the inventor's existing company or those marketed through new ventures (Fig. 3.4). They account for $\$ 422$ million in current dollars (or 54\%) of the total cumulative sales of ERIP inventions. On an invention-by-invention basis, the difference is even more pronounced. Cumulative sales of licensed technologies have averaged $\$ 8.3$ million, compared with $\$ 4.6$ million for technologies commercialized through new ventures and $\$ 1.9$ million for those commercialized by the inventor's existing company.

The greater sales resulting from licensing may be attributed to several factors. Licensing agreements are likely to be concluded when the licensee perceives a considerable market for the technology and the licensor finds a firm that has access to channels and markets that the inventor could not tap on his or her own. Licensees tend to be established enterprises that have already gone through the start-up phase that new ventures or recent enterprises still must experience. Licensing thus can provide an avenue for rapid market entry (Weigand, 1986).

\subsubsection{Sales Versus Program Costs}

Table 3.4 compares the sales of ERIP technologies to costs, in terms of program appropriations and grant awards, on a cumulative basis using both current and 1994 dollar values. Figure 3.5 plots just the 1994 dollar values. They both illustrate the substantial increase of invention sales over both program appropriations and grant awards.

As an indicator of the effectiveness of ERIP, the $\$ 961$ million (in 1994-\$) in cumulative sales generated by ERIP inventions can be compared with program costs. Approximately $\$ 47.5$ million (in $1994-\$$ ) in grants were awarded through 1994, and program appropriations totaled about $\$ 124$ million. Thus, the ERIP program has generated a 20:1 return in terms of the value of sales to grants, and an 8:1 return in terms of sales to total program appropriations. ${ }^{5}$

These ratios have remained remarkably steady since 1986 when they were first calculated. Only in the early 1980's, when the program was less than a decade old, was the ratio of sales to program costs considerably lower. These results illustrate that there can be a considerable lag time in the ability to observe the overall benefits of commercialization programs. In at least some situations a full decade is required before a program's impacts can be fully appreciated.

\footnotetext{
${ }^{5}$ These ratios are slightly higher-23:1 and 9:1-when current dollars are used. This is because the grants and program appropriations precede the sales of ERIP technologies and thus are more markedly inflated.
} 


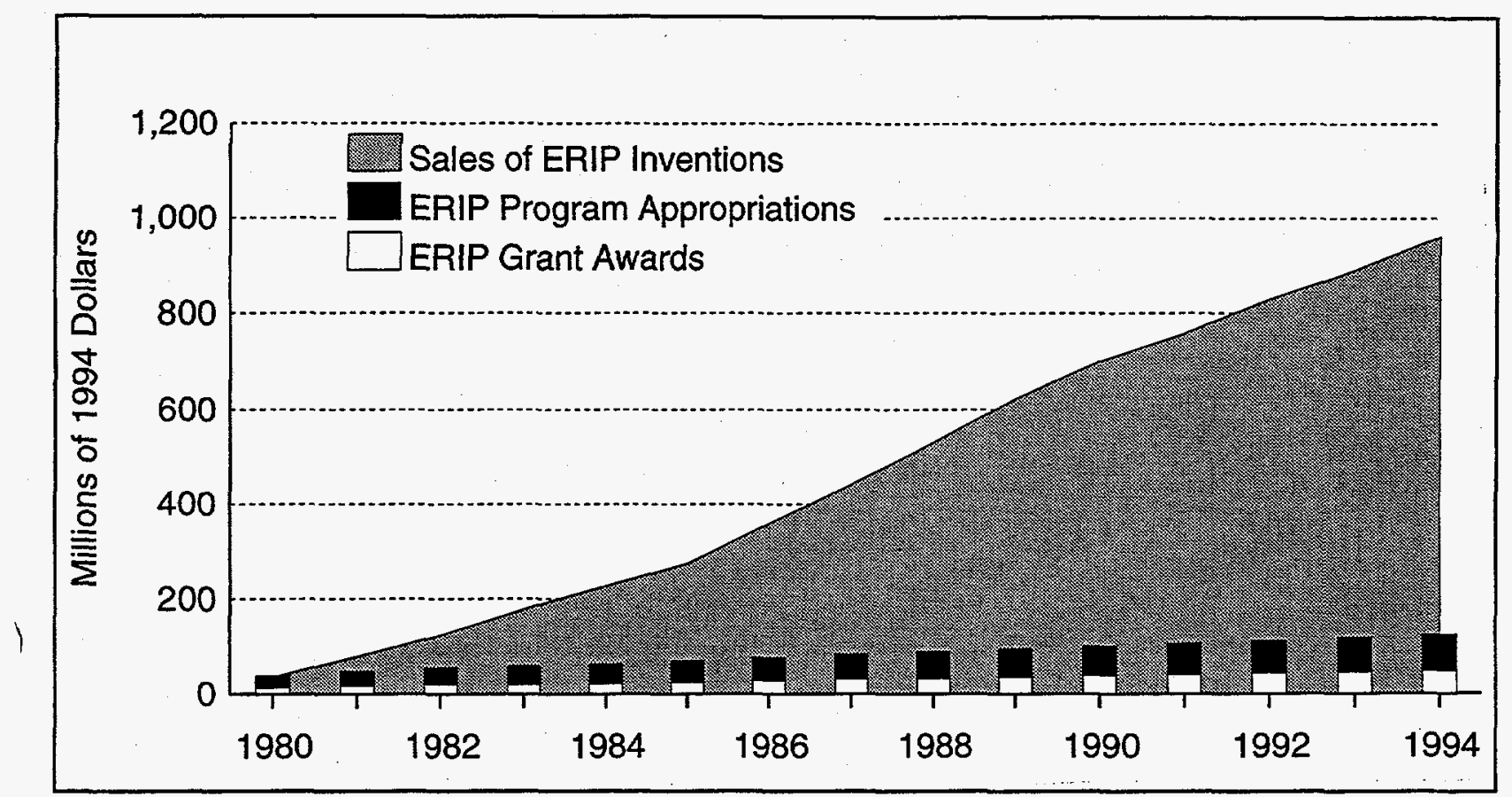

Fig. 3.5. Cumulative grant awards, program appropriations, and sales of ERIP technologies.

\subsection{ROYALTIES FROM LICENSED ERIP TECHNOLOGIES}

Actual royalty data are available for 13 of the 51 licensed inventions. These 13 inventions account for $\$ 9$ million in royalties through 1994. Royalties were estimated for the other 38 licensed inventions where actual data were missing for some or all years by using either an assumed royalty rate of $5 \%$ of licensed sales or a rate provided by the inventor. ${ }^{6}$

Over the duration of the Energy-Related Inventions Program, ERIP technologies have generated more than $\$ 22.6$ million in royalties (or the equivalent of $\$ 28.2$ million in 1994-\$) for their inventors. The timeline of inventions with royalties and royalty payments tracks the commercial progress of ERIP inventions, in general. Royalties reached an all-time high in 1989 of over $\$ 2.8$ million (in 1994-\$), after which they began a slight decline to under $\$ 1.9$ million in 1992 (see Appendix C, Table C.1 for annual data). Royalties have since rebounded in the last two years reaching almost $\$ 2.3$ million (in 1994-\$) in 1994. Figure 3.6 depicts the cumulative royalties resulting from ERIP technologies in 1994 dollars over the last 15 years.

\footnotetext{
${ }^{6}$ While royalty rates for ERIP inventions range widely, $5 \%$ is a common rate. In a recent analysis of 95 licenses by Parr (1995), 5\% was the most common rate, although, it was used in only 16 of the 95 licenses. The distribution of rates in Parr's study ranged from $0.5 \%$ to $30 \%$. Among the ERIP inventions, royalty rates range from $2 \%$ to $20 \%$.
} 


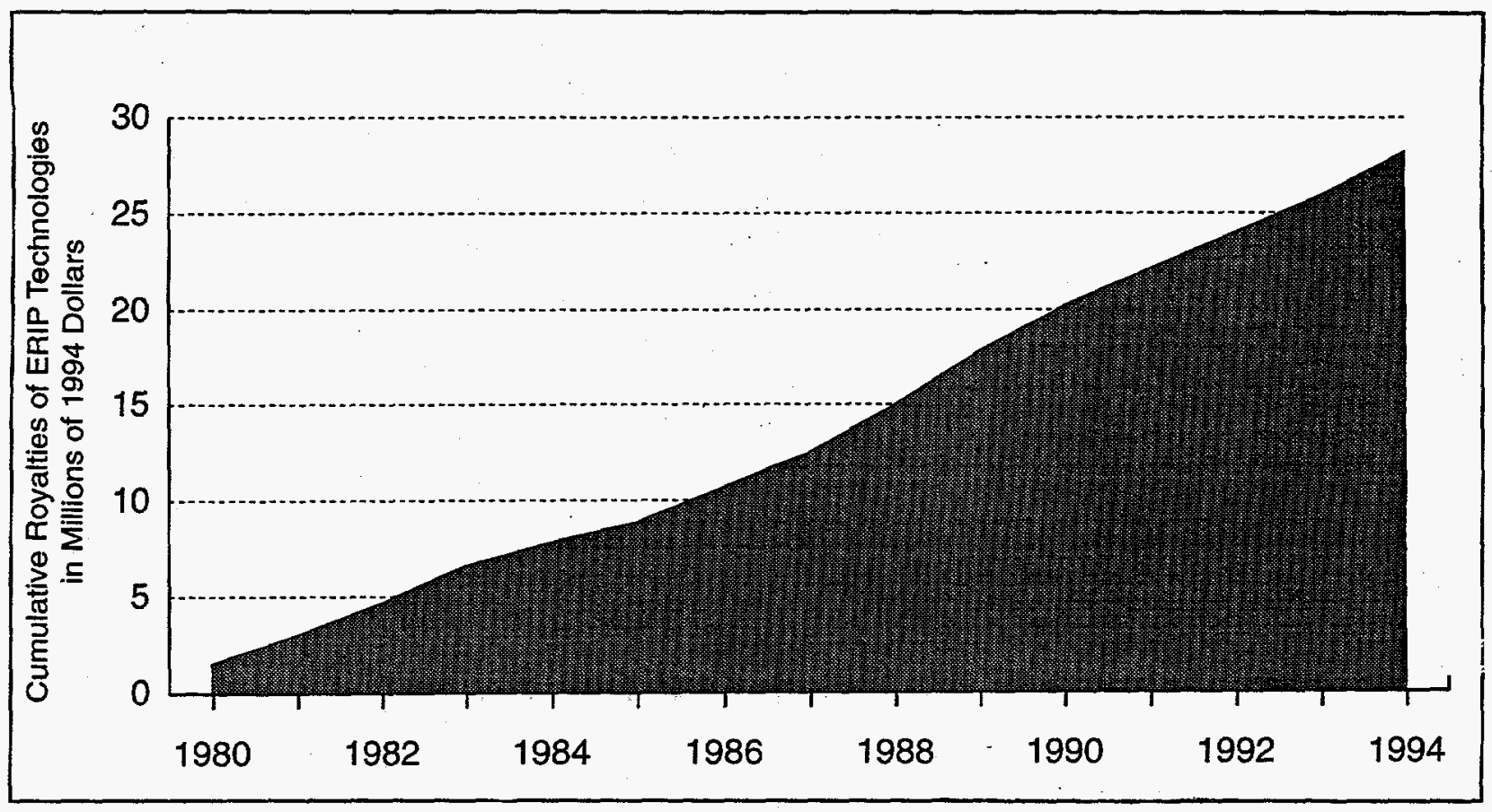

Fig. 3.6. Cumulative royalties from ERIP technologies.

\subsection{COMMERCIALIZATION DIFFICULTIES FACED BY ERIP INVENTORS}

The 1995 survey of ERIP inventors or contacts for the first time questioned respondents on the level of difficulties, if any, they experienced in trying to bring their inventions to the market. The results are displayed in Table 3.6. Respondents were divided into those with and without sales and were asked about difficulties they may have faced with 12 commercialization activities. With the exception of a range of "other activities" noted by minorities of both categories of inventors, raising funds for capital investment was identified as the most difficult activity for both inventor categories, followed by marketing activities and expanding into full production. Activities such as purchasing suitable equipment, technical planning, product quality assurance, and recruiting qualified technical staff were judged by both groups as the least difficult activities:

Differences in rating of activities did not vary greatly between the inventors with sales and inventors without sales. In the three activities where the differences were greatest-raising funds for capital investment, purchasing suitable equipment, and prototype developing and testing-inventors without sales

${ }^{7} A$ wide variety of issues were raised in this category, the most prominent of which could be grouped under institutional issues, such as complying with regulations or standards, and credibility issues, such as convincing a decision maker of the technology's feasibility. 
Table 3.6. Commercialization Difficulties Faced by ERIP Inventors ${ }^{2}$

\begin{tabular}{|c|c|c|c|c|c|}
\hline Commercialization Difficulties. & $\begin{array}{l}\text { Average } \\
\text { Rating by } \\
\text { Inventors } \\
\text { With Sales }\end{array}$ & $\mathbf{N}$ & $\begin{array}{l}\text { Average Rating } \\
\text { Inventors } \\
\text { Without Sales }\end{array}$ & $\mathbf{N}$ & $\begin{array}{l}\text { Average } \\
\text { Rating for } \\
\text { All Inventors } \\
\mathrm{N}=\mathbf{4 5 0}\end{array}$ \\
\hline Raising funds for capital investment & 7.9 & 47 & 8.9 & 82 & 8.6 \\
\hline Marketing & 7.0 & 50 & 6.7 & 78 & 6.9 \\
\hline Expanding into full production & 6.1 & 39 & 6.6 & 56 & 6.4 \\
\hline Building an effective nanagenent & 5.4 & 43 & 5.3 & 59 & 5.3 \\
\hline Prototype developing and testing & 4.4 & 48 & 5.3 & 90 & 5.1 \\
\hline Business planning & 4.7 & 47 & 5.1 & 82 & 5.0 \\
\hline Market assessment & 5.3 & 51 & 5.0 & 93 & 4.9 \\
\hline Recruiting qualified technical staff & 4.6 & 46 & 4.4 & 71 & 4.4 \\
\hline Product quality assurance & 4.7 & 48 & 4.1 & 54 & 4.3 \\
\hline Purchasing suitable equipment & 3.4 & 46 & 4.6 & 64 & 4.3 \\
\hline Technical planning & 4.3 & 48 & 3.9 & 87 & 4.0 \\
\hline Other & 9.2 & 12 & 9.0 & 16 & 9.0 \\
\hline
\end{tabular}

a To calculate each of these weighted averages, the percent of promising inventions was multiplied by $98 / 450$, the percent of other inventions was multiplied by $352 / 450$, and the two products were added.

Difficulty levels range from one (not at all difficult) through ten (extremely difficult) or not applicable.

rated the difficulties greater than the inventors with sales. Given the findings that both groups rated raising funds for capital investment the most difficult activity and that inventors without sales rated the activity as noticeably more difficult than inventors with sales, it would appear that access to capital is a critical key to commercialization success. Small firms and independent inventors typically have significant barriers to acquiring financial resources, which is one of the rationales for government-supported grant programs such as ERIP. These financial barriers are discussed in greater detail in Chapter 6. 



\section{COMMERCIAL PROGRESS OF SPINOFF TECHNOLOGIES}

Chapter 3 documented the commercial progress of the energy conservation and supply technologies supported by ERIP. This chapter focuses on commercial activities that have resulted in part, or in total, from completion of an ERIP project, but that do not involve the ERIP technology as defined in the original invention disclosure to NIST. A majority of these spinoff activities are serendipitous by-products-they were unplanned, unforeseen, and unintended when the ERIP project was initially conceived. Several on the other hand, were the result of strategic planning that occurred when the inventors were unsuccessful with their original technical approach or their initial primary markets. Altogether, they represent tangible benefits that have accrued from the Program.

\subsection{DEFINITION AND CLASSIFICATION OF SPINOFF TECHNOLOGIES}

The term "spinoff" has acquired a number of meanings in the technology transfer literature, as reviewed by Brown and Wilson (1993). For the purposes of this evaluation, a spinoff from an R\&D project is "any technology development or market application that occurred as the result of the ERIP project and was not the technology or market that the original project addressed." The fact that spinoffs are distinct from the technology or market that the original project addressed forms the basis of a classification of spinoffs that distinguishes between alternative market applications and second-generation technologies. Alternative market applications occur when the results of an $R \& D$ project are subsequently applied to a market or use that differs from the originally intended application. Whether or not an application qualifies as sufficiently different to constitute a spinoff is sometimes difficult to assess. Employing concepts from Meyer and Roberts (1986), market newness increases as one moves from existing or intended customers to a new market niche, a new market segment, and an entirely new market. Using this terminology, we would consider anything other than the "existing or intended customers" to be different enough to be a spinoff application. Second-generation technologies occur when the technology that was the subject of an R\&D project is significantly altered and enhanced through subsequent R\&D. Adapting some of the concepts described in Meyer and Roberts (1986) to the measurement of technology newness, we distinguish between three different types of second-generation technologies: major enhancements, new/related technologies, and new/unrelated technologies. To apply this classification, it is first necessary to understand the concept of "core technologies" - the discrete, unique skills and techniques that embody a technology. Some of the components of this core are "key technologies" that provide the technology with its competitive edge and differentiate it from what is currently in the marketplace. Other components of the core are "base 
technologies" that are commonly available in the marketplace. Major enhancements occur through the addition of new base technologies to the core. New/related technologies occur through the addition or replacement of one or more key technologies, but the retention of some of the base technologies. New/unrelated technologies have no overlap with the key or base technologies that comprised the original technology. Minor incremental improvements are not considered here to constitute the kinds of change that herald a generational breakthrough.

\subsection{ILLUSTRATIONS OF SPINOFFS FROM ERIP TECHNOLOGIES}

\subsubsection{Alternative Market Applications}

Most of the spinoffs have occurred when the results of an ERIP project were applied to a market or use that was different from the originally intended application. For example, one ERIP-supported inventor developed an apparatus for mixing and deaerating drilling mud for injection into oil wells. Subsequently, the inventor experienced a leak in his basement and used the technology to mix a sealant. A new basement sealing business grew out of this experience, employing the same technology that had been developed for oil well use. Another ERIP inventor received a DOE grant to develop a thin conductive film to provide radiant heating in buildings. The film was subsequently used to create military decoys (for heat-seeking missiles) that were successfully deployed in Operation Desert Storm. Similarly, DOE provided a grant to an inventor to develop a process to recover finely crushed or powdered coal from refuse piles at coal mines. This application proved non-economic, but the technology has been successfully adapted as a belt filter press to dewater municipal wastes. (See Brown and Wilson, 1993, for a description of additional examples.)

Alternative market applications may require little follow-on technical or business development to be useful in their new context. On the other hand, some technologies have required significant redesign and re-engineering to prepare them for their new uses.

Significant technology redesign has characterized instances when components of ERIP technologies have been used in whole new systems. A typical example involves microprocessorcontrolled technologies. For instance, ERIP supported the development of a lightweight frame and tension form to ease production of parabolic solar reflectors. The technology included a microprocessor that allowed remote monitoring of the device's performance. The solar collector device proved difficult to sell, but the microprocessor control technology has been successfully used in building security systems. Another ERIP project focused on the development of a temperature control system for buildings. This 
technology and line of business failed for the ERIP participant, but as a result of ERIP funding, the inventor's start-up company gained expertise with microprocessors and was able to move into a new product area - the design and construction of microcomputers for specialized laboratory and corporate uses.

In contrast, some alternative market applications of ERIP technologies have required limited redesign, but because of their new market focus have necessitated a new business venture. This situation tends to occur when the new application involves a clear market disjuncture, requiring new sales and marketing approaches.

Typically, one would expect the amount of redevelopment to increase with market newness, but there are exceptions to this rule. One ERIP inventor developed a portable space heater and gas burner to prevent frost damage to orange groves. The heater draws a large volume of warm air through a duct from above the crops by means of a large blade fan; the warm air is then directed across a propane-fired flame heater where it is heated and then directed out of the apparatus at ground level into the crops to be protected. The heating system was developed (with funding from a DOE/ERIP grant) and successfully used in orchards. A subsequent use of the technology was to prevent frost damage to exotic greenhouse plants (i.e., a new "market niche"). More recently, the technology was used to heat football players at a Superbowl. Although this is an entirely new "market" for the invention, only minor redesign work was required. Figure 4.1 illustrates the development of these market application spinoffs in terms of the dimensions of market and technological newness.

Alternative market applications may emerge from technologies regardless of whether or not they were successfully applied to their originally intended use. Of course, with success comes the resources needed to explore alternative markets and to support any technical or business investments required to exploit spinoff opportunities. This case of success-breeding-success has typified the alternative market applications that have spun off from ERIP projects.

\subsubsection{Second-Generation Technologies}

Over the decade of experience with ERIP spinoffs, second-generation technologies have been less prevalent than alternative market applications. Where they have emerged, altered or enhanced, technologies have typically occurred after the original technology was found to be technically or economically impractical. 


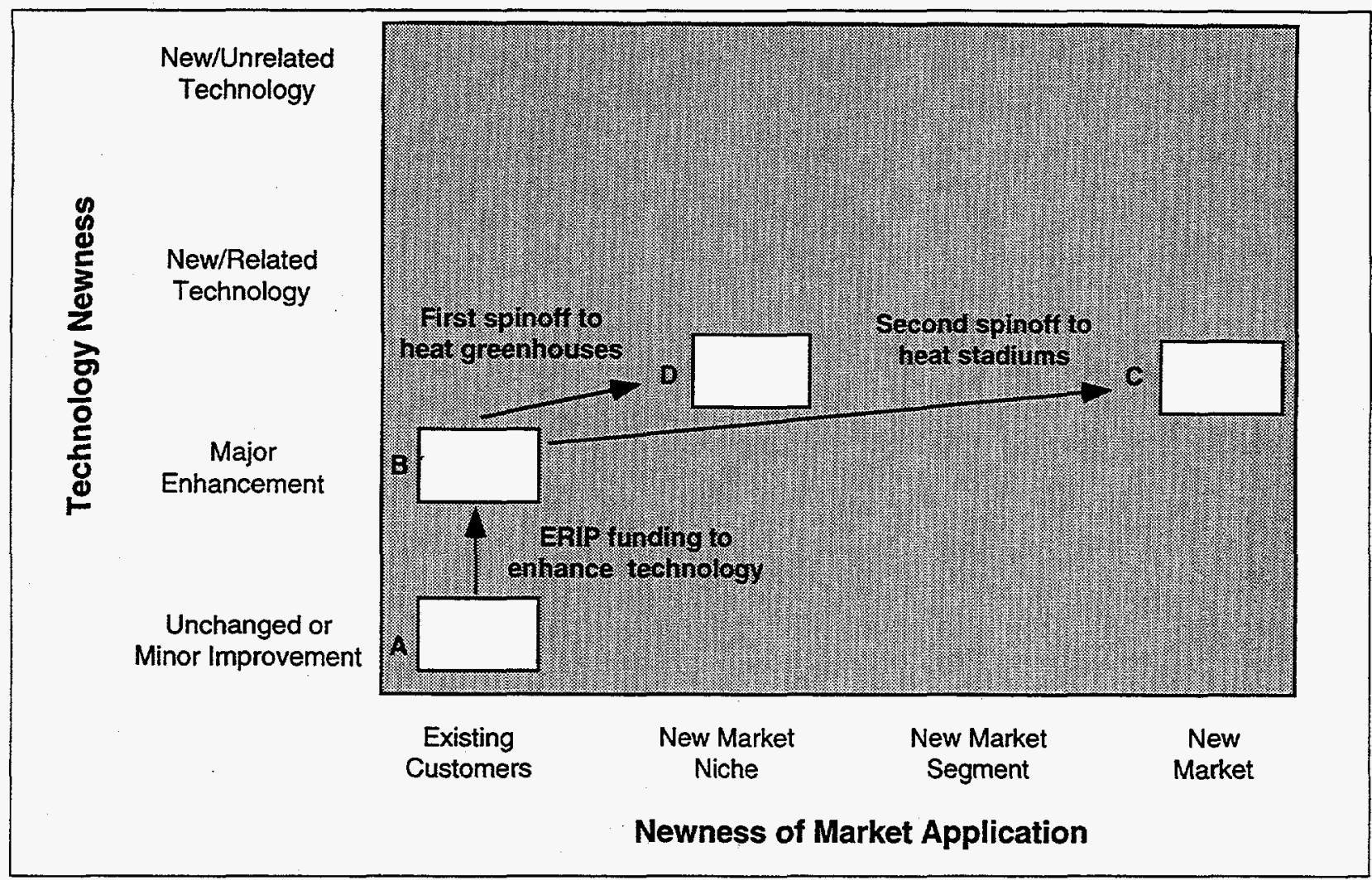

Fig. 4.1. A market application spinoff of an ERIP technology.

For instance, one ERIP inventor received a grant to develop a polymerizing process for thermosetting resins that used pulsed xenon arc discharge lamps. With DOE funds in hand, the inventor imbedded the polymerization process within an electromagnetic field, significantly accelerating the curing process. This was an unanticipated technological breakthrough which significantly altered (and improved) the nature of the product, making it economically viable. Figure 4.2 illustrates the transition between first and second-generation technologies for the polymerization system described above. The ERIP grant supported the development of the initial key technology, the A-B transition illustrated in Fig. 4.2. Embedding the system in a magnetic field represented a significant technological shift that enabled the inventor to establish a new product family (Meyer and Utterback, 1993). Since this technological shift enabled the inventor to more effectively address the needs of his original market (the B-C transition in Fig. 4.2), there is no movement indicated along the market newness axis.

Usually these second-generation technologies build on experiences in addressing a particular market or industry-specific need. The original technology advances to the prototype development or 


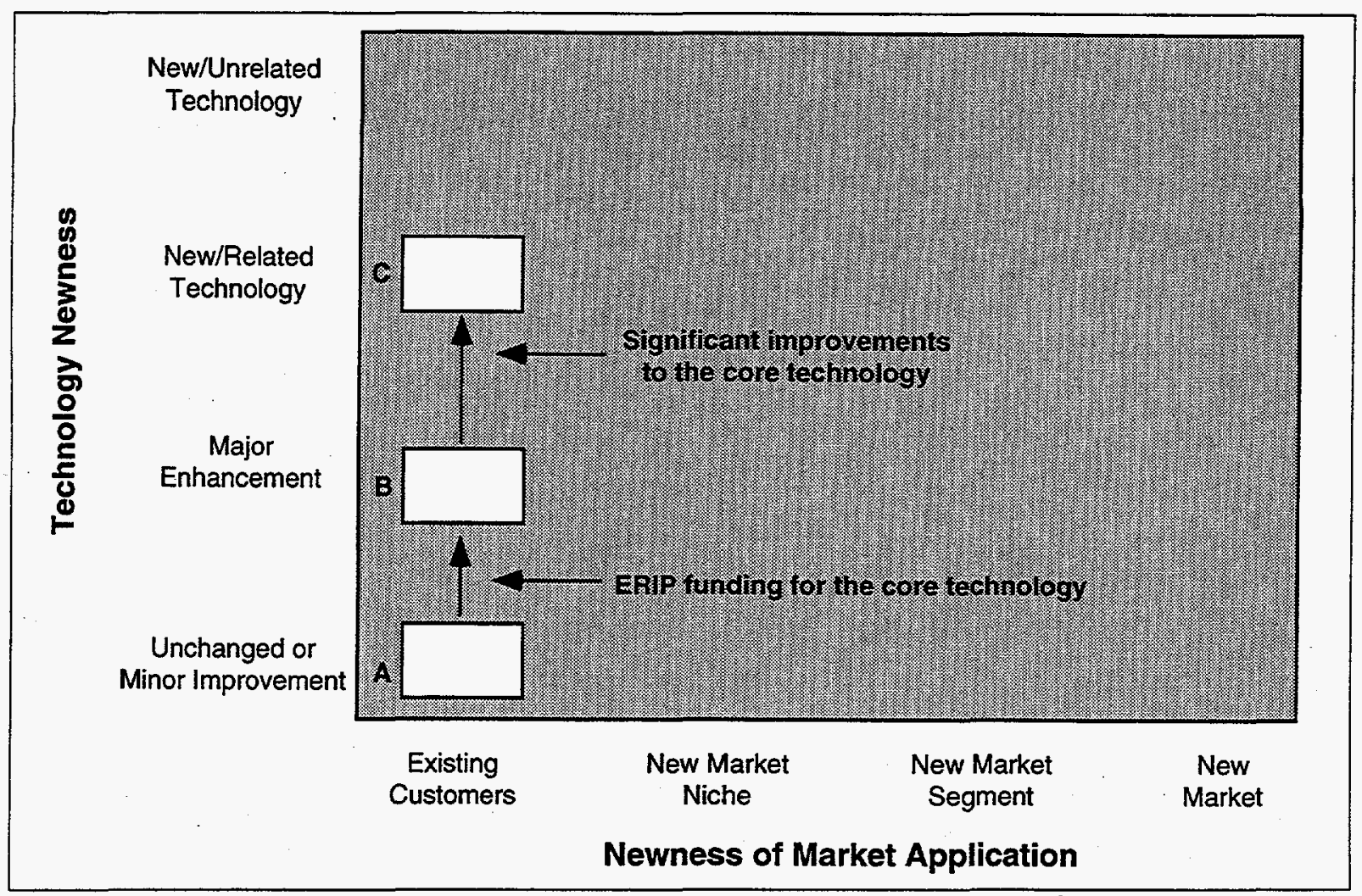

Fig. 4.2. A second-generation ERIP technology directed toward existing markets.

initial market introduction stages, and it encounters limited, if any, market success. User feedback from that initial effort helps orient the next round of technology development.

This was the case with an energy conservation measure for ice rinks. The spinoff from this technology also is an example of a second-generation technology resulting from modifying the "key technologies" that comprise its core. The original technology supported by ERIP involved applying a foam directly to the ice at night, using a specially-designed machine; and then removing the foam to a storage area during the day. The "new but related" technology involves a low-cost retrofit to the standard Gamboni ice-prepping machine; it uses a similar type of foam, but the foam is created each day and disposed of each night, eliminating the additional storage space required by the original technology. ERIP enabled the inventor to develop the more marketable second-generation technology as the result of the market knowledge acquired in trying to commercialize the original technology.

Second-generation technologies sometimes result from first-generation "enabling technologies" - that is, the original R\&D investment makes possible the realization of other product improvements. For instance, one ERIP participant received a grant to develop a packing process that allows fruits and vegetables to be transported without refrigeration. With this packing system successfully in place, the 
inventor commissioned the development of a new hybrid tomato with a particularly appealing flavor that is retained during shipment because of the unrefrigerated packing and shipping process developed during the ERIP project. In this case, the original technology was transformed by replacing a "base technology" (off-the-shelf fruits and vegetables) with a newly developed "key technology" (the new hybrid tomato).

\subsubsection{Linkages Between ERIP Technologies and Their Spinoffs}

One of the most important issues in evaluating spinoffs from ERIP investments is the nature and strength of the spinoff's linkage to the original ERIP support. Linkage is easiest to establish if the connection between the original technology and its spinoff is highly visible, such as support for core technology development or specific market applications. These linkages can be readily perceived in terms of modifications in products and processes or in the adoption and use of a technology by a new set of users. Other types of substantive linkages to the original technology development effort may be much less visible, such as critical support for business development activities.

Core technology linkages are the strongest connections, because they occur when the R\&D investment was instrumental in developing a core technical ensemble with multifaceted potential for further development and application. In the case of the mixing technology previously described, the mixing device developed with ERIP support was then applied to a variety of spinoff market applications. Thus, the link between the initial core technology and the subsequent market application is strong.

A similar example is illustrated in Fig. 4.3. ERIP funds were applied to the development of a metal detector, which was a key technology in the initial technical core of a materials separation technology. The detection system was initially applied to recovery of aluminum and then modified to separate iron from municipal waste (the B-C transition in Fig. 4.3). The device to separate iron is considered a market application spinoff. The success of the initial detection system suggested a dramatic revision of the technology to allow detection of metal impurities in the production of silicon wafers (the $\mathrm{C}$-D transition in Fig. 4.3). This development is considered a second-generation technology, and its application will be directed to dramatically different markets.

Application linkages occur when the supported project is intended to develop an alternative application of an already well developed core technology. In these instances, the linkage between the supported application and other outgrowths of the core technology is tenuous. Such is the case of the aluminum-epoxy composite technology mentioned above. Since the inventor had developed, tested, and marketed other applications of the basic aluminum-epoxy technology before applying for ERIP funding, 


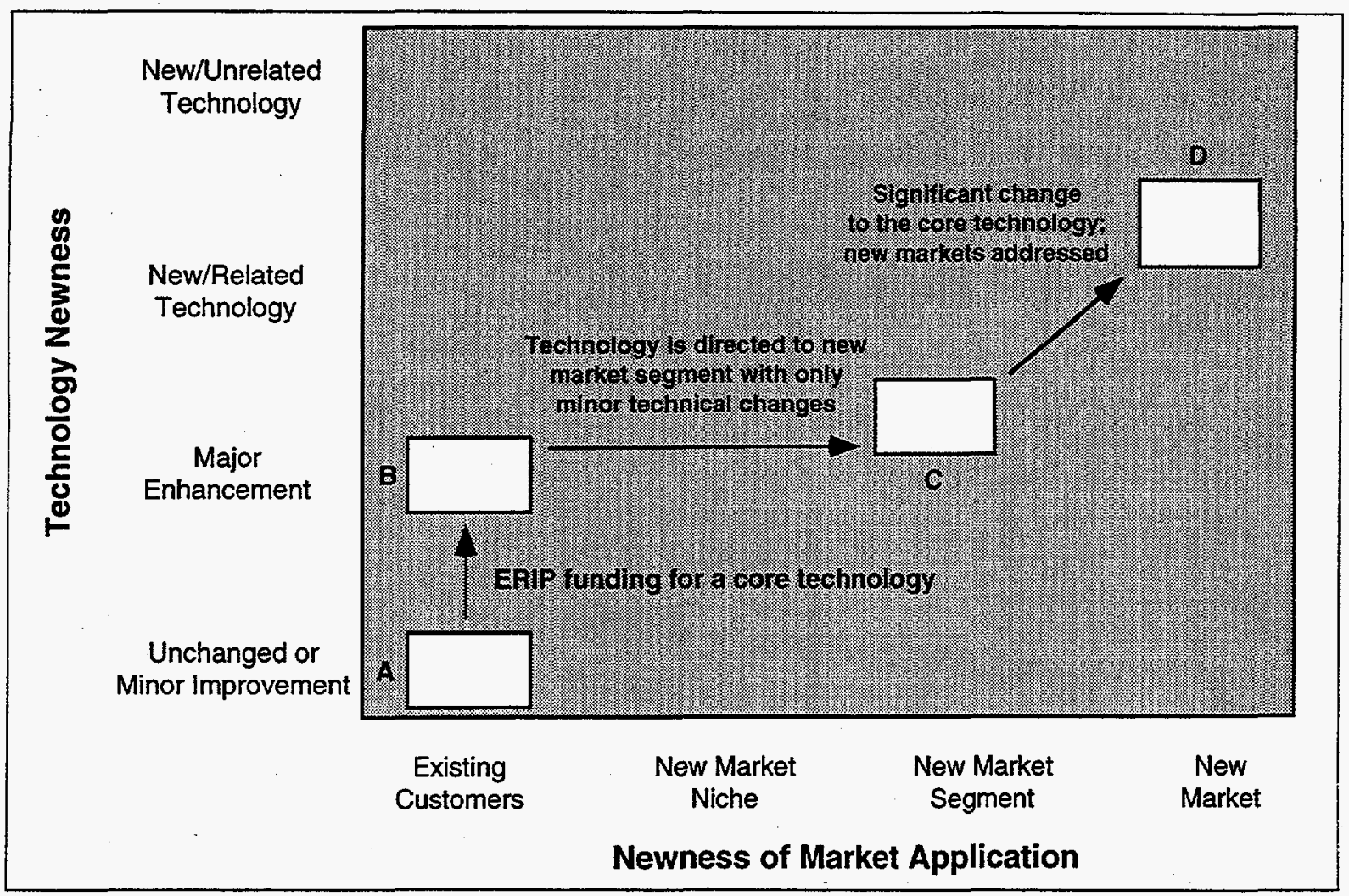

Fig. 4.3. Spinoffs generated from a core technology along both market and technology dimensions.

the ERIP technology itself is a spinoff of the original technology. Thus, additional applications of the core technology are not considered ERIP spinoffs.

Low visibility linkages such as the influence of R\&D investment on human resources and business capabilities may have an important impact on subsequent spinoff activity. There have been several examples within the ERIP program in which ERIP funding kept an inventor active or a small business alive until it could amass the necessary resources for successful technical or business development. Governmental organizations such as the Small Business Administration whose primary mission is related to small business development would be especially interested in this sort of linkage.

\subsection{SALES OF SPINOFF TECHNOLOGIES}

Numerous spinoffs from ERIP projects are in early stages of development by ERIP participants - in fact, some are simply ideas that remain to be pursued. Others have already generated sales. Information on the commercial progress of spinoff technologies was first collected during the 1989 ERIP evaluation. As a result, our statistics on spinoff sales probably under-represent spinoffs from ERIP 
inventors who participated in the early rounds of evaluation surveying (i.e., 1985 and 1987) but who did not participate in recent surveys. In 1991, the data collection benefitted from greater clarity in the definition of spinoff technologies. The same definition (described in Section 4.1) was used in the 1993 survey and again in the 1995 survey.

The 1995 survey identified 52 spinoff technologies that had generated sales. These technologies are offshoots of 44 different ERIP projects. These spinoffs had accumulated about $\$ 77$ million in sales in current dollars ( $\$ 88$ million in 1994-\$) through 1994 (Appendix C, Table C.2).

Most of these 52 spinoff technologies are alternative market applications, 37 of them spun off from ERIP technologies that themselves had experienced sales, and 15 spun off from ERIP technologies that had no sales. Thus, in a majority of cases it appears that success has bred (or enabled) further success.

The commercial impact of ERIP's spinoff activities has grown substantially over the lifetime of the program. Most of the spinoff technologies identified to date are fairly recent developments, with sales beginning in 1985 (see Fig. 4.4). It is likely that the role of such ERIP by-products will continue to increase as those entrepreneurs participating in ERIP strive to maximize the market potential of their inventions. One challenge for the Program is to find ways to assist less entrepreneurial ERIP inventors with robust core technologies to exploit their spinoff opportunities.

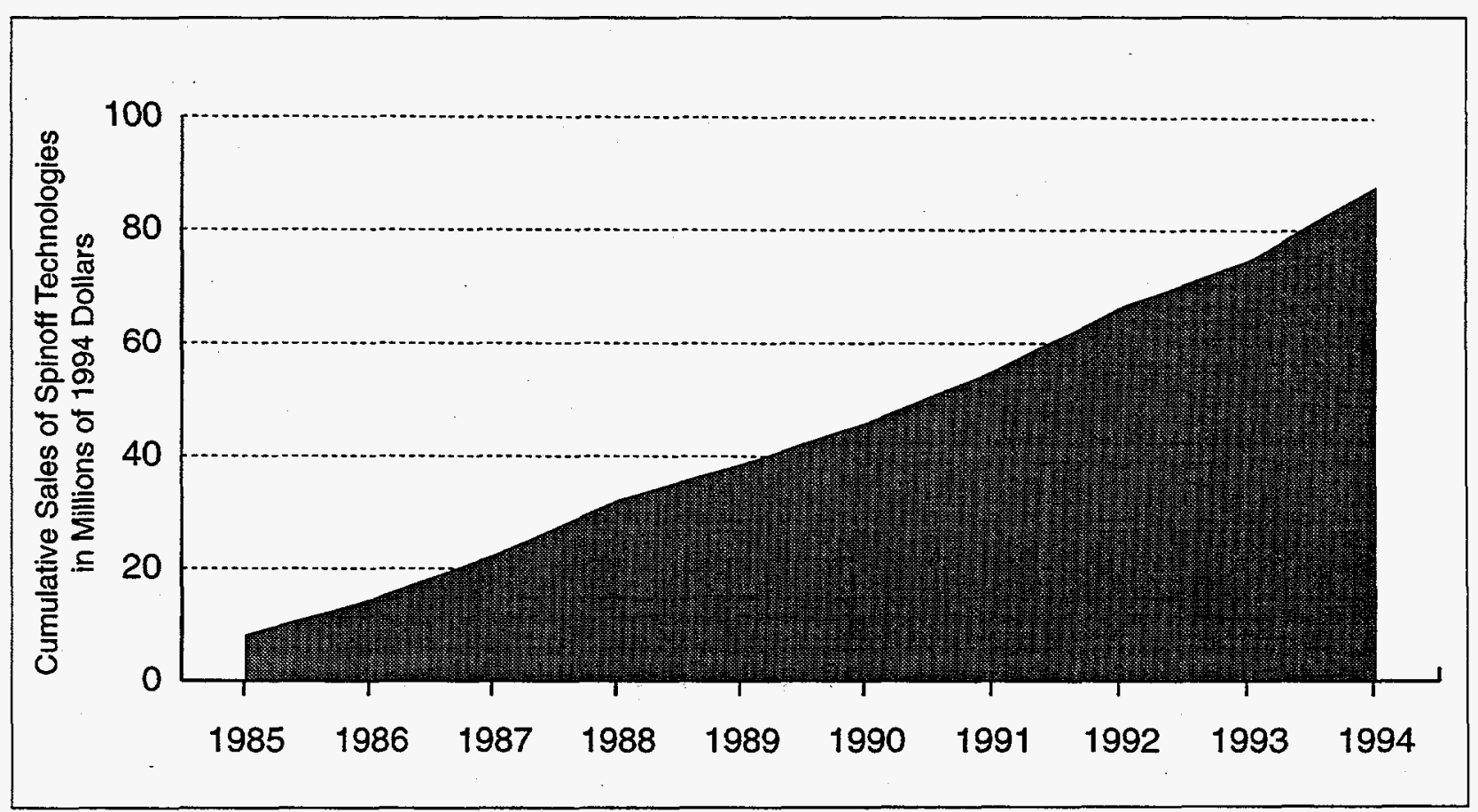

Fig. 4.4. Cumulative sales of 44 spinoff technologies. 


\section{EMPLOYMENT, TAX REVENUES, AND EXPORTS}

Technological innovation is a major determinant of economic growth-creating jobs, tax revenues, and exports. Small businesses have been particularly successful in commercializing innovations (The Futures Group, 1984), and they dominate job creation. Between 1976 and 1984, small firms accounted for $60.5 \%$ of the 17.0 million net new jobs in the United States (Kirchhoff and Phillips, 1988). This chapter looks at the employment associated with ERIP technologies, both in 1994 (the most recent year with data) and in previous years. Tax revenues and exports are also examined.

\subsection{EMPLOYMENT ASSOCIATED WITH ERIP TECHNOLOGIES}

The data collected by the 1995 ERIP survey are able to address only the direct effects of the program-employment generated by the development, production, and marketing of ERIP technologies. The diversity of consumer and industrial markets served by ERIP inventions argues against the use of a single multiplier to estimate the indirect and induced effects. Thus, we are excluding potentially significant employment impacts in our discussion of employment associated with ERIP technologies. Since ERIP has been collecting employment data for a decade, it is more appropriate to use the term "job years" rather than jobs; the former term giving a more accurate picture of the longevity of the program's employment benefits.

The 1995 survey solicited data on the number of direct, full-time equivalent (FTE) employees working on the ERIP technologies in 1993 and 1994. Similar employment data for 1985 through 1992 were collected during previous ERIP evaluations and are presented as job years for comparison purposes (Table 5.1). These data indicate that there are a significant number of job years sustained over a considerable period of time by the technical development, production, and sales of ERIP technologies. Previous data documented that most of this employment occurs at the production/marketing stage, although significant numbers of jobs can be generated while developing prototypes. Further, it is not until the production phase that employment can be fully supported from revenues generated by the invention itself. In prior stages, work on the technology is largely subsidized by other sources.

Employment data for 1993 and 1994 are available for most of the inventions with direct sales (since the inventors themselves tended to be interviewed), but they are available for less than half of the inventions being commercialized through license agreements (since not all of the licensees were interviewed). When sales are known, but employment data are unavailable, employment estimates are generated from ratios of 
Table 5.1. Number of Direct Full-Time Equivalent (FTE) Job Years Sustained by Sales of ERIP Inventions

\begin{tabular}{|c|c|c|c|c|c|c|}
\hline Year & $\begin{array}{l}\text { Known } \\
\text { ETE's } \\
\text { Sustained } \\
\text { by Direct } \\
\text { Sales }\end{array}$ & $\begin{array}{l}\text { Estimated } \\
\text { Based on } \\
\text { Direct } \\
\text { Sales }\end{array}$ & $\begin{array}{l}\text { Known } \\
\text { Suless } \\
\text { by Licensed } \\
\text { Sales }\end{array}$ & $\begin{array}{l}\text { Estimated } \\
\text { Sustained by } \\
\text { Licensed } \\
\text { Sales }\end{array}$ & $\begin{array}{l}\text { Sustained by } \\
\text { Tinventions } \\
\text { Without } \\
\text { Sales }\end{array}$ & Totals \\
\hline 1985. & 302 & 14 & 34 & 20 & 126 & 496 \\
\hline 1986 & 259 & 27 & 43 & 81 & 100 & 510 \\
\hline 1987 & 365 & 14 & 11 & 81 & 129 & 600 \\
\hline 1988 & 400 & 17 & 65 & 108 & 147 & 737 \\
\hline 1989 & 416 & 31 & 91 & 139 & 120 & 797 \\
\hline 1990 & 441 & 37 & 75 & 157 & 132 & 842 \\
\hline 1991 & 305 & 23 & 73 & 67 & 140 & 608 \\
\hline 1992 & 359 & 39 & 86 & 79 & 104 & 667 \\
\hline 1993 & 333 & 76 & 133 & 22 & 68 & 632 \\
\hline 1994 & 422 & 104 & 136 & 18 & 77 & 757 \\
\hline
\end{tabular}

ERIP sales to FTEs. (These ratios are provided in Table 5.2.) For example, in 1994, the sales-to-FTE ratio for ERIP inventions with known sales and employment, was $\$ 90,000$. An additional $\$ 14.2$ million of sales in 1994 is associated with an unknown number of FTE's. Using the $\$ 90,000$ ratio of sales to jobs, the estimated FTEs supported by $\$ 14.2$ million of direct sales is 104 . Table 5.1 shows the values of known vs. estimated FTEs, for ERIP technologies sold either directly or indirectly.

Employment benefits of the program in particular years can by determined readily by dividing the previous year's appropriations (assuming lags in expending funds and cause-and-effect employment results) by the following year's FTEs. In 1984, Federal ERIP appropriations totaled about $\$ 4.3$ million (in 1984 dollars) thereby sustaining an estimated 496 job years in 1985 . The cost in terms of appropriations was about $\$ 8,700$ (in 1994 dollars) spent to support each job year. In 1993, Federal ERIP appropriations amounted to about $\$ 6.4$ million, which sustained 757 jobs years in 1994. The approximate cost of a job year in 1994 dollars was $\$ 8,450$. During the 10 year period $1985-1994$, ERIP sustained an estimated 6,646 job years at an approximate total funding of $\$ 59.5$ million or $\$ 8,950$ per job year (in 1994 dollars). 
Table 5.2. Sales per FTE Employee

\begin{tabular}{|c|c|c|}
\hline \multirow{2}{*}{ Year } & \multicolumn{2}{|c|}{ Ratio of Sales to FYE s (in thousands of dollars') } \\
\hline & Direct Sales & Licensed Sales \\
\hline 1985 & 94 & 210 \\
\hline 1986 & 102 & 292 \\
\hline 1987 & 99 & 353 \\
\hline 1988 & 89 & 249 \\
\hline 1989 & 111 & 171 \\
\hline 1990 & 108 & 110 \\
\hline 1991 & 140 & 113 \\
\hline 1992 & 148 & 116 \\
\hline 1993 & 107 & 105 \\
\hline 1994 & 90 & 126 \\
\hline
\end{tabular}

*current dollars

Over the past decade, the ratio of sales to jobs has ranged from annual averages of $\$ 89,000$ to $\$ 148,000$ (in current year dollars). These values do not deviate markedly from the national average for small businesses with some R\&D. In 1984 the U.S. General Accounting Office estimated this ratio to be $\$ 107,000$ (in 1982 dollars). The ERIP ratios of sales to jobs is nearly twice the ratio of value added per job $(\$ 56,530)$ estimated in an evaluation of the New York Manufacturing Extension Program (Nexus Associates, Inc., 1996). The dollar volume of sales per FTE working on an ERIP project under a licensee is generally higher, ranging from $\$ 105,000$ to $\$ 353,000$ over the same ten-year period. However, over the past five years, the ratios of sales to jobs has varied within a fairly small range, from $\$ 90,000$ to $\$ 140,000$ for both modes of commercialization.

On the basis of these results, Fig. 5.1 portrays the estimated numbers of job years supported by ERIP technologies. The total ERIP employment ranges from a low of 496 in 1985 to a high of 842 in 1990 . It is thought that much of the variation in this range is the result of the fact that many of the ERIP firms are new and small and frequently are supporting their employees on non-ERIP sales. Figure 5.2 indicates that in every year since 1985, more job years have been sustained by inventions sold directly by inventors than by licensed inventions, despite the fact that licensing has generated greater sales. This is because the ratio of sales to jobs is lower for inventions sold directly than for licensed sales. 


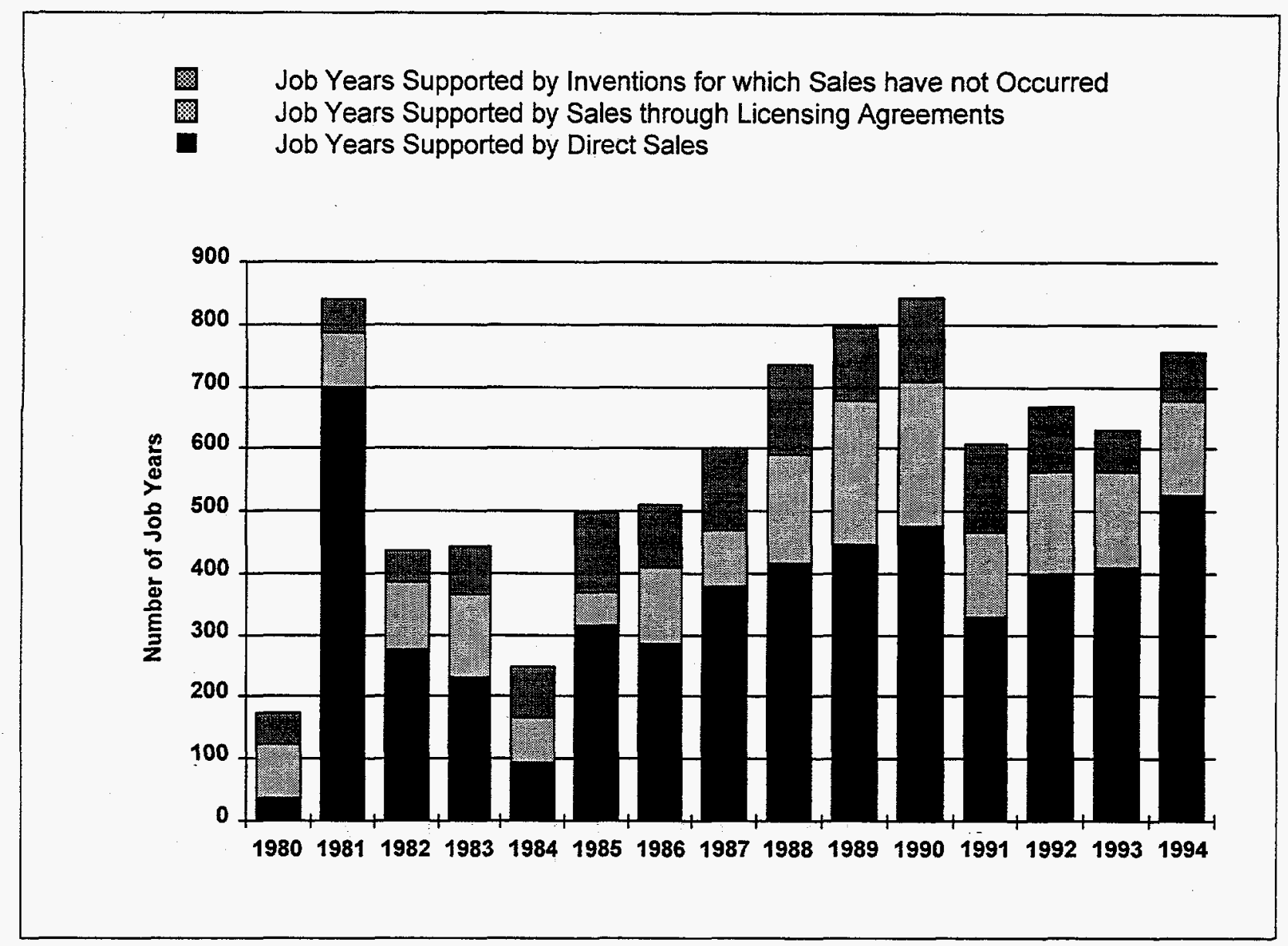

Fig. 5.1. Number of job years supported by ERIP technologies, 1985 to 1994.

The job year estimates presented in Table 5.1 are not equivalent to the direct employment effects of the Program. To equal the direct effects, one would have to assume that the activity associated with the ERIP project did not displace any pre-existing economic activity; therefore all of the employees working on ERIP projects would have been unemployed if it were not for the ERIP expenditure. In periods of high unemployment (such as 1991 and 1992), it is reasonable to assume that some fraction of these employees would have been without employment, but the exact number is unknown. We believe that the estimates presented in Table 5.1 represent upper bounds for the direct effects of the Program; however, they should be considered as underestimates of the total employment effects of ERIP since indirect and induced effects are not included.

The distribution of jobs per invention is highly skewed (Fig. 5.2). In 1994, for example, seven inventions with known employment each supported more than 40 job years, for a total of 397 job years. Another two inventions with known employment each supported 20 or more job years for a total of 56 . Thus, 


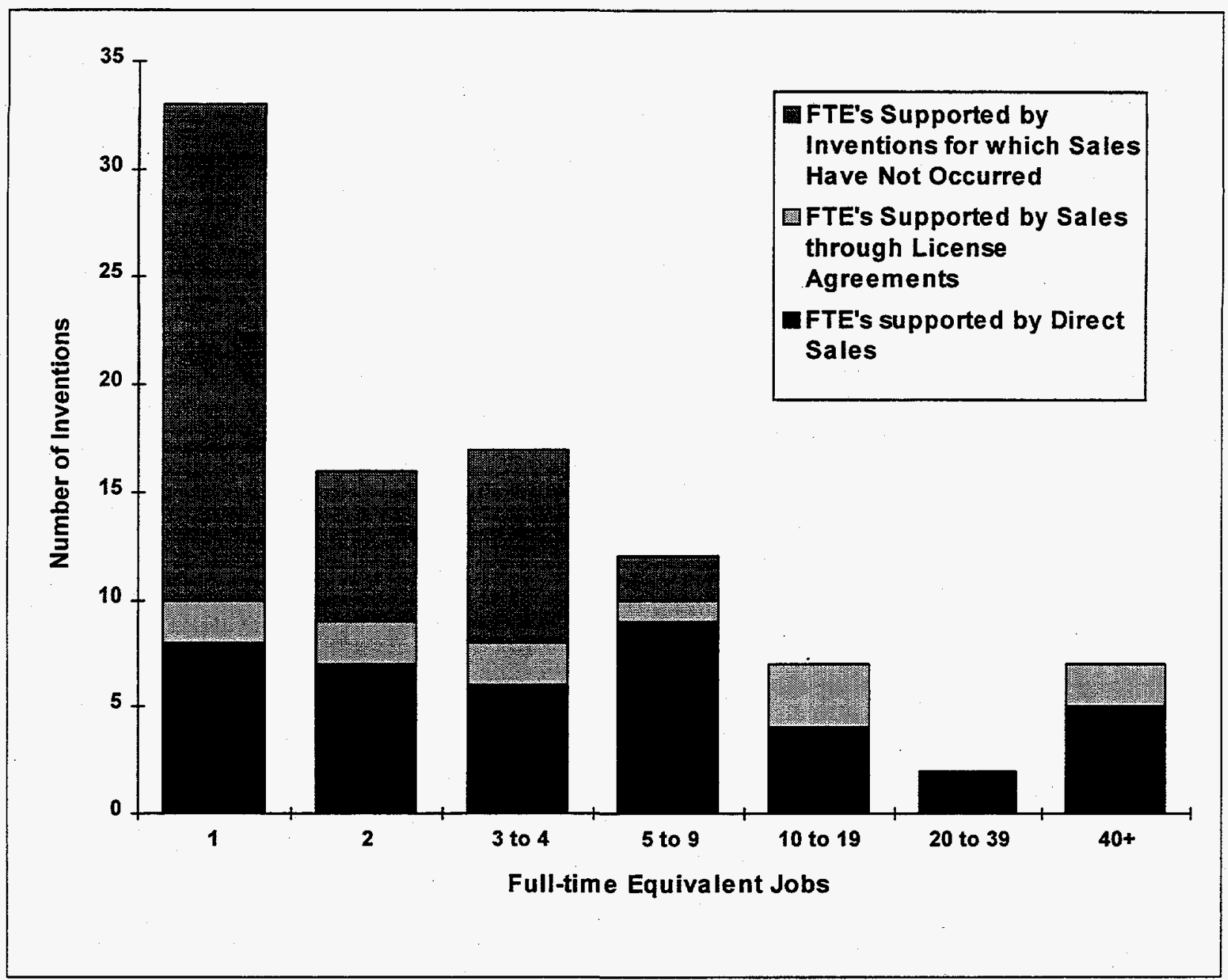

Fig. 5.2. Distribution of FTE's for ERIP technologies supporting jobs in 1994.

these nine technologies supported $60 \%$ of the 757 job years supported by all ERIP projects in 1994 . This is similar to the trend documented in previous ERIP evaluations.

\subsection{TAX REVENUES FROM ERIP-GENERATED EMPLOYMENT}

This section employs a simple and conservative approach to estimating the returns to the U.S. Treasury associated with the Energy-Related Inventions Program. It uses the number of employees working on ERIP technologies, and weights this employment by the average federal individual income tax to estimate the total federal taxes that can be attributed to the Program. A similar methodology has been used in other program evaluations (Chrisman, Hoy, and Robinson, 1987). 
In 1992, the average federal individual income tax per return was $\$ 4,272$ (U.S. Department of Commerce, Bureau of the Census, Table No. 537, p. 347, 1995). Based on the statistics presented in the previous section, 757 FTE employees worked on ERIP technologies in 1994. Assuming that each of these employees paid $\$ 4,511$ (1994-\$) in federal individual income taxes, this amounts to a total return of $\$ 3.4$ million to the U.S. Treasury in 1994. This total is over half the 1994 ERIP appropriations.

Additional tax revenues are associated with royalty payments on ERIP inventions, corporate income taxes, state and local sales and income taxes, and personal income taxes paid by indirect employment beneficiaries of the program.

\subsection{FOREIGN SALES OF ERIP \\ TECHNOLOGIES}

The international market for energy technologies is large and growing. It is estimated that by the end of the decade, the world market for energy-efficiency goods and services will reach $\$ 84$ billion annually, and the world market for renewable energy technologies will reach $\$ 150$ billion (U.S. Department of Energy, 1995b). This growth has been fueled by trends including the transition of many centrally planned economies to market-based economies, continued high population and economic growth in developing countries, and greater recognition that energy
One ERIP technology that shows promise of substantial foreign sales is Russell D. Ide's hydrodynamic/multideflection pad bearing. Mr. Ide set up his own company, KMC Inc., in 1983 to manufacture general mechanical components. As a result of making thrust bearings for oil drilling rigs, Mr. Ide exploited the need for improved thrust bearings in motors running submersible pumps for oil production.

Based on his early design work, Mr. Ide received a $\$ 75,000$ ERIP grant in 1988 to design, manufacture, and test prototype deflection pad bearings for equipment used for high speed turbines, high load electric motors or gear boxes, air or gas compressors, and air conditioning or refrigeration equipment. His invention employs flexible pads which form fluid wedges to allow optimum bearing operation. Energy losses due to friction are minimized by using fluids as a wedge between moving parts and the pads. The flexibility of the pads allows them to deflect under load, thereby optimizing the action of the fluid lubrication.

The KMC bearing provides a number of benefits over its pad bearing competitors, including decreased energy losses, smaller size, higher load carrying capacity, greater stability, reduced noise, and reduced manufacturing costs.

Mr. Ide entered into a partnership with a British company in 1988, which has since invested substantially in $\mathrm{KMC}$ and provided the firm with business advice and contacts.

Sales of the hydrodynamic/multi-deflection pad bearing have risen steadily since reaching the market. Sales in international markets were small, however, until 1992 when they began increasing rapidly. Mr. Ide has received useful information on foreign market potential from the Department of Commerce and believes the market amounts to $\$ 500$ million annually. Trade shows have been the primary mechanism for reaching foreign markets, supplemented by advertising in trade magazines. $\mathrm{KMC}$ has sold its pad bearings in 8 foreign countries, including Japan where success has come about by working with a Japanese partner who acts as a licensee. KMC is pursuing the same strategy in Europe.

\section{Sales of hydrodynamic/multi-deflection pads} show promise in international markets. 
efficiency and renewable energy technologies offer many environmental benefits, including reduced global warming.

The 1995 survey marks the second time inventors were asked to estimate the magnitude of their foreign sales. Previous evaluations did collect data on foreign patents and identified significant activity, but the success of foreign marketing activities beyond patenting was never assessed.

Forty-two of the respondents to the 1995 survey indicated that they have sold their ERIP technologies to customers in one or more foreign countries. This represents $29 \%$ of the 144 ERIP technologies with sales. Altogether, foreign sales for these ERIP technologies totaled $\$ 45.2$ million (in current dollars), to date. Of this total, $\$ 38$ million was accounted for by six technologies. The experience of one inventor who has successfully tapped several foreign markets is described in the sidebar. 


\section{ACQUIRING FINANCIAL SUPPORT}

Small firms often face significant financial barriers to technological innovation. They typically have a pressing need for funds to support the testing, feasibility studies, market analysis, and business planning necessary to develop and market their technologies. The small firms' internal resources to support technological innovation are rarely sufficient, and loans are difficult to obtain because of insufficient collateral and inadequate business skills. This sometimes leads to mergers or equity financing with larger firms - thereby compromising the relative advantage that the small business brings to the innovation process (Horesh and Kamin, 1983). Perhaps more often, small businesses and independent inventors simply are unable to secure adequate financial resources, a failure that causes premature project termination or an under-financed product that fails in the marketplace. ERIP provides several types of assistance to help participating inventors acquire the resources they need. This section describes the effectiveness of this assistance.

In the ERIP population, as in almost all populations of developing technologies or business startups, only a small percentage of the technologies become big winners in terms of market success or fund raising. This produces dramatic differences across the population in investment patterns, and makes it difficult to discuss the experience of "the typical ERIP technology" in raising capital. For this reason, this section will discuss investment not only in terms of averages but also in terms of the distribution of funding across the ERIP population of technologies. In addition, to examine the relative success of ERIP grants in inducing other outside funding, leveraging ratios are calculated and discussed. A leveraging ratio is the ratio of external funding to the amount of the ERIP grant.

\subsection{THE NATURE OF ERIP'S FINANCLAL ASSISTANCE}

The monetary grants awarded by the ERIP are provided to meet at least some of the financial needs of small firms and individuals engaged in developing energy-related technologies. But not all ERIP inventors receive grants, and for those who do, the grants may provide only a small contribution toward the total amount of capital required to bring a new technology to market. The 1994 grants ranged from $\$ 90,050$ to $\$ 99,960$, a range that has increased to reflect inflation over the life of the program.

As a result of this direct financial assistance, the Program can indirectly help meet the inventor's additional needs for financing. Inventors report they often use their NIST evaluation and ERIP award as a source of credibility to aid them in attracting additional resources to further develop their technologies. ERIP support makes the inventor's company more credible in the eyes of potential investors. Finding a first 
investor when seeking capital is perhaps the most challenging part of the whole process. Most investors do not want to be first, but if someone else is willing to participate, especially a federal agency based on an impartial evaluation of an invention's technical and commercial promise, others are more likely to follow. For example, in one instance, an inventor parlayed a \$50,000 ERIP grant into a $\$ 1$ million award from a private industrial research institute. Another inventor used his $\$ 75,000$ award to garner $\$ 10$ million in funding from a multinational corporation. In several other cases, inventors have been able to secure matching state or local grants, based on their ERIP support.

The critical timing of ERIP funding is also documented in the case of a solar water heating technology. The ERIP grant arrived when the business was financially vulnerable, and it helped the business surmount engineering and commercialization hurdles and survive long enough to subsequently become successful. In another case, an innovative approach to reduce refrigeration costs in the shipping of farm produce, the credibility of ERIP, along with the Program's timely financial support, was important in subsequent fund raising. Retained earnings from the technology today amount to more than 20 times the ERIP grant.

There are also instances where successful fund raising by ERIP inventors cannot be attributed to the Program's financial or technical assistance. For instance, a new technology for natural gas pipelines was promoted by an ERIP inventor with a strong entrepreneurial track record, a history of successful interaction with venture capitalists, and substantial personal resources. The inventor persuaded industry to invest over $\$ 2$ million in the development of his ERIP technology. For this inventor, ERIP was just one of several sources of development funds, and neither the credibility of the ERIP program nor the ERIP funds themselves apparently played crucial roles in the inventor's acquisition of additional capital. In this situation, although the ERIP technology never reached the marketplace, a spinoff was reported to have generated substantial sales.

Finally, the program performs a brokering function for many of its inventors. In addition to directing inventors to alternative sources of funding, the program also disseminates information about promising inventions to potential funding sources. This is done through the distribution of fact sheets and participation in technology fairs. Given the fact that most inventors cannot fully develop, much less commercialize, their inventions solely on the funding provided by ERIP, it is important to study the amounts and sources of non-ERIP inventor funding. 


\subsection{THE COST OF TECHNOLOGICAL INNOVATION}

A review of the literature indicates that ERIP inventions are typical of technological innovations at large, in terms of their development and commercialization costs. At the lowest end of the cost spectrum, Myers and Marquis (1969, p. 60) found that two-thirds of 567 surveyed innovations cost less than $\$ 100,000$ (or $\$ 404,000$ in 1994 dollars) for development to the point of use. They examined a broad range of innovations, mostly minor, that were named as commercially significant by firms in five manufacturing industries. Kamin, et al. (1982) found that $82 \%(\mathrm{~N}=18)$ of the 22 small-business technological innovations they studied required total technological expenditures of $\$ 1$ million ( $\$ 1.5$ million in 1994 dollars) or less. Their innovations were sampled from two major industrial sectors-electronics and chemicals. At the more expensive extreme, a 1973 survey of innovation cost patterns for Canada found that the average cost per project was $\$ 3.3$ million ( $\$ 11.0$ million in 1994 dollars) for a diverse sample of 83 process and product innovations. Sixty percent of the innovations cost less than $\$ 1$ million ( $\$ 3.4$ million in 1994 dollars) to develop (Stead, 1976).

Current information on total costs of technological innovation is available for 82 of the 144 ERIP inventions with sales (i.e., those that were interviewed in 1995). Seventy-eight percent of these inventions cost less than $\$ 1$ million to develop to the point of market entry or beyond (Fig. 6.1). The average total investment in ERIP inventions with sales is $\$ 1.2$ million in current dollars or \$1.7 million in 1994 dollars. This high mean value reflects the skewed distribution of the cost data: 10 inventions with sales have incurred costs of more than $\$ 3$ million, while 21 inventions with sales have incurred less than $\$ 100,000$ in development costs. This wide variation in the cost of commercializing a new technology is due in part to industry, firm, location, and technology differences.

Some of the most successful ERIP inventions are products-simple in both their manufacture and content-with minimal capital requirements. There are several "do-it-yourself" solar technologies for homeowners, for instance. Other successful ERIP technologies require only nominal capital input for commercialization because they are simply a unique way of combining and utilizing components that are already available. These technologies frequently are assembled and distributed through subcontractors, thereby allowing the inventor to achieve considerable sales on a relatively small capital outlay.

At the other extreme, several ERIP inventions with large capital requirements are process technologies in the steel and related industries. Technical problems related to testing and refining industrial processes are costly, and these technologies often require the operation of full-scale pilot plants or expensive retrofits and demonstrations in fully-operating plants. In contrast to the average cost of $\$ 1.7$ million per invention with sales, the average ERIP grant is quite small. Its importance is due to its timing; the grant 


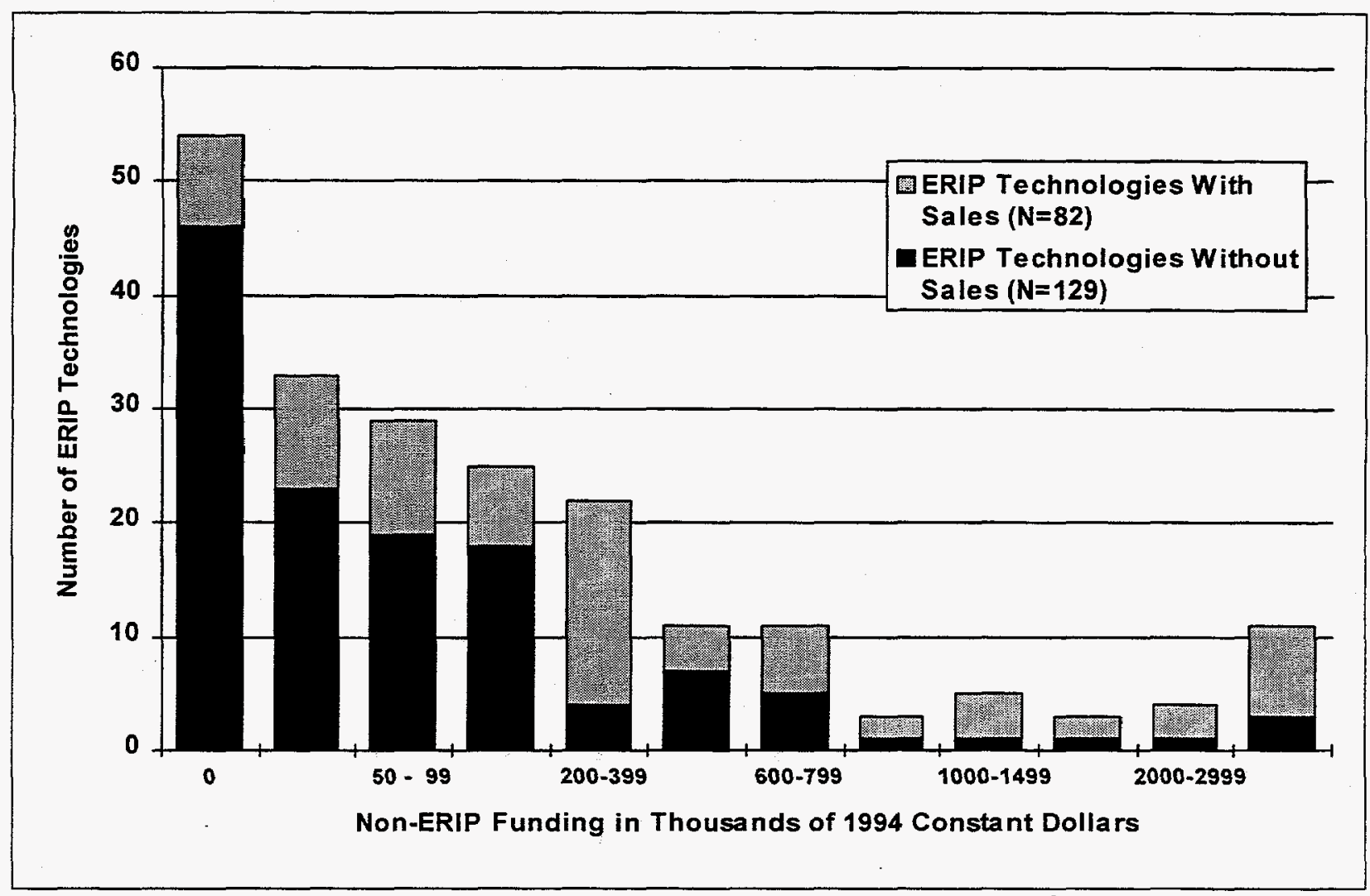

Fig. 6.1. Distribution of funds raised by 211 inventors, exclusive of ERIP grants.

often arrives at a critical juncture when the inventor's funds are exhausted and other sources are unwilling to assist.

Significant levels of funding also have been acquired by inventions without sales, although those with sales have attained considerably higher average levels of funding. Information on funding is available for 129 inventions that had not experienced sales by the end of 1994. Many of these ERIP inventors report that development of their ERIP invention was retarded by lack of development capital. It is noteworthy that some $61 \%$ of these 129 inventions raised less than $\$ 100,000$ above and beyond DOE's ERIP grant. Figure 6.1 illustrates the fact that inventions with sales dominate the higher end of the development funding continuum whereas inventors without sales dominate the lower end of the funding continuum.

The financing of small business innovation has been portrayed as proceeding from personal resources and other informal sources of "friendly money" to more formal sources of capital, including equity financing by venture capital firms and stock offerings. Unfortunately, there is little systematic evidence concerning when various sources of innovation financing tend to become available and when they are exhausted. "Start-up" capital has been shown to be dominated by the personal resources of the founder. However, since 
the start-up phase occurs early in the long process of product development, and since in any event many small business innovations are developed by existing companies, start-up capital is only one piece of the financing puzzle.

The 182 ERIP grant recipients in our sample raised more funding from all sources after receiving NIST's favorable technical review than before NIST's approval (Fig. 6.2). This is true of inventors with sales, as well as those without sales. Altogether, the 182 grant recipients surveyed in 1995 were able to raise \$11.41 (in 1994 dollars) from all sources for every ERIP grant dollar received for a leveraging ratio of 11.41. The ratio can be divided based on the time the funding was obtained as follows:

- $\$ 2.26$ of this was raised prior to application to the Program,

- $\$ 2.21$ was raised while their application was being processed by NIST,

- \$1.04 was raised after NIST approval and before the ERIP grant, and

- \$5.90 was raised after receipt of their ERIP grant.

It should be emphasized that these four time periods vary greatly in duration, and this fact alone can influence the funding distribution considerably.

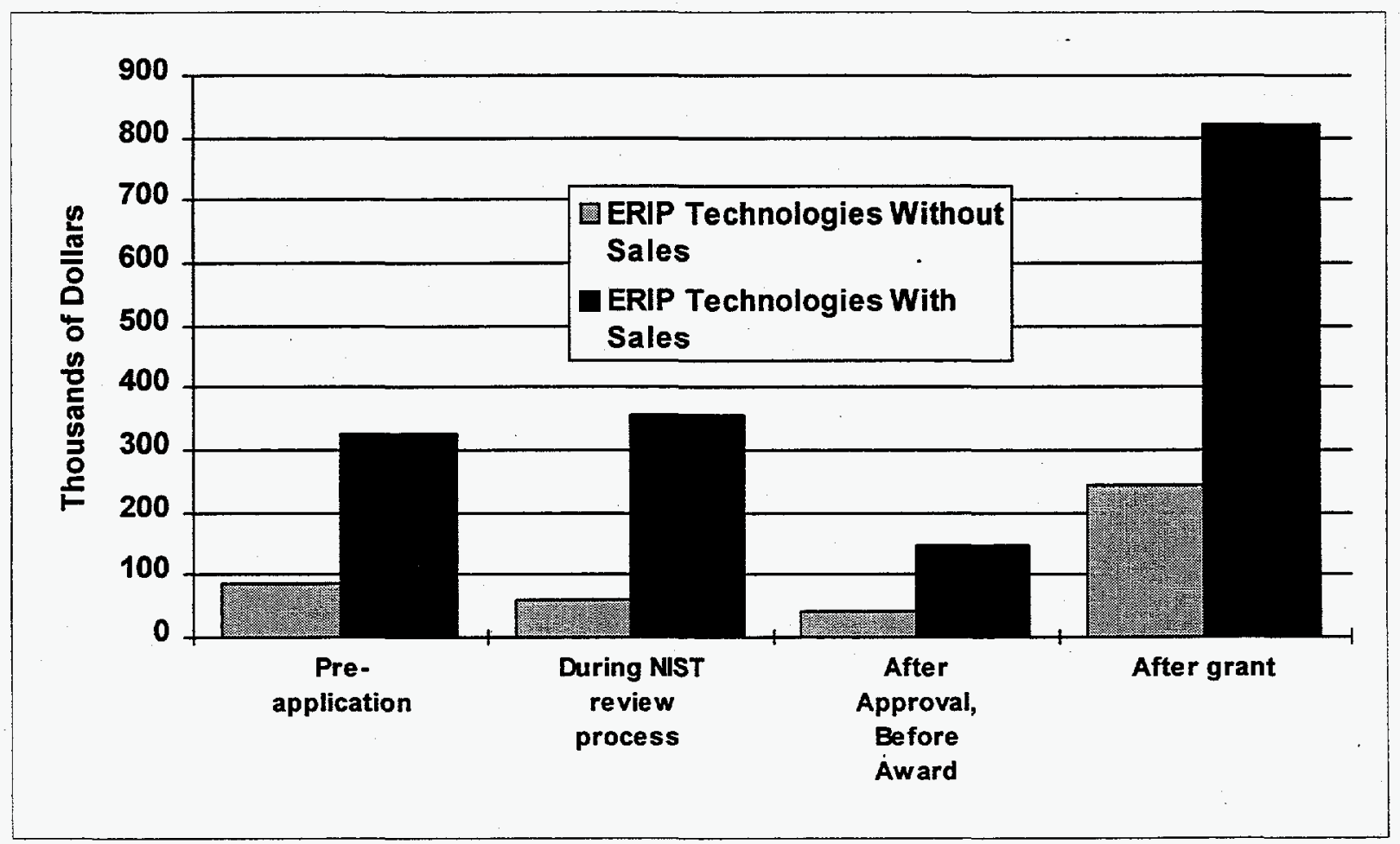

Fig. 6.2. Average funds raised before and after the ERIP Grant.

(Sample: 182 technologies with grants surveyed in 1995.) 
These levels of non-ERIP fund raising are dramatically higher than those reported in 1993, when the ratio of total non-ERIP to ERIP funds was found to be $\$ 3.88$. Non-ERIP funding between application and grant was $\$ 0.94$ in 1993 , while average post-award non-ERIP funding was $\$ 2.01$.

These increases can be attributed to the combined effect of sample definition (i.e., the focus on inventions with grants), the use of inflation-adjusted dollars, and the success of a small number of highly successful fund raisers. Surprisingly, these dramatic increases in average levels of non-ERIP funding have not been paralleled by an improvement in the fortunes of the typical ERIP inventor, but can be attributed to just a few technologies. This is because the overwhelming majority of funding of all types is acquired by a small fraction of the technologies, and substantial levels of funding acquired by any one technology can impact the average leveraging ratio of the entire program. For instance, a designer of friction-reducing bearings reported over $\$ 12$ million in funding in 1993-94. This level of funding is almost equivalent to the sum of the grants received by ERIP awardees surveyed in $1995(\$ 14,461,000)$ and produces an average increase in the post-grant leveraging ratio of 0.86 .

Since average levels of non-ERIP funding are so strongly influenced by the behavior of individual technologies, and since the distribution of non-ERIP funding is characterized by a small number of technologies which are heavily funded and a large number which are lightly funded, much of the discussion of non-ERIP funding will be conducted from the perspective of leveraging ratios rather than average values of funding.

The dramatic variations among individual technologies in the magnitude of their non-ERIP funds are illustrated by Fig. 6.3. The majority of the funds raised by ERIP inventors have been brought in by a small group of technologies whose inventors have been highly effective in fund raising. Fifty-four percent of all non-ERIP funds has been raised by the five most highly leveraged technologies, while $72 \%$ of all nonERIP funding is associated with the 13 highest leveraged technologies. These 13 technologies are also responsible for over half of all sales from the 182 grant recipients responding to the 1995 survey. At the other extreme, 42 technologies (23\%) raised no non-ERIP funds, while $38(23 \%)$ raised funding less than or equal to the size of their ERIP grant.

The same general pattern is observed when post-grant funding is examined (Fig 6.4). Those technologies with leveraging ratios of 10 or more are responsible for over $80 \%$ of all post-grant funding, while $62 \%$ of grant recipients reported leveraging ratios of less than one.

It is revealing that sales volume does not correlate well with leveraging ratio. This reflects the presence within the ERIP population both of sophisticated and capital intensive technologies requiring 


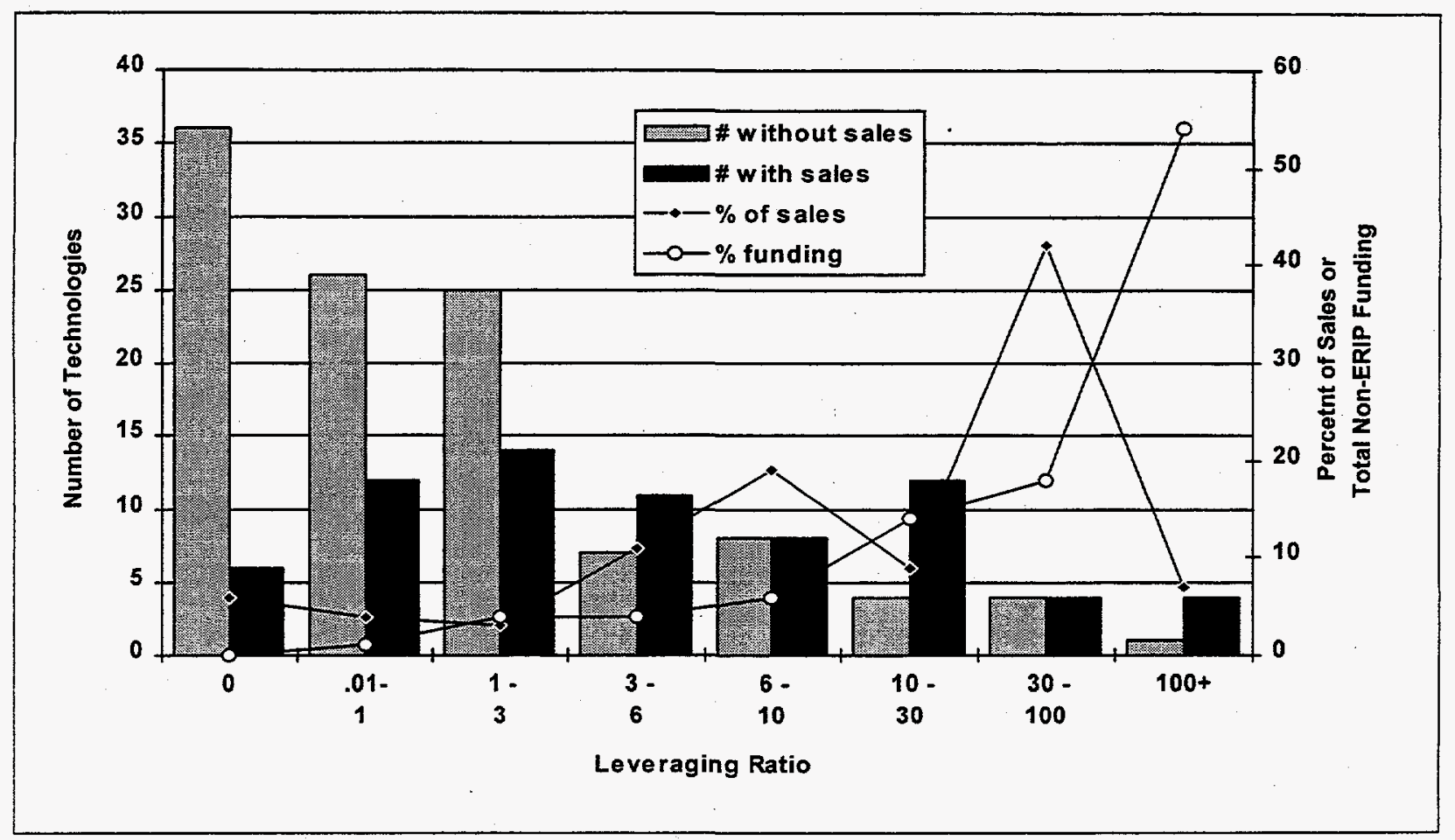

Fig. 6.3. Leverage ratios for all funds (constant 1994 dollars) raised by ERIP inventors.

(Sample: 182 cases with grants surveyed in 1995.)

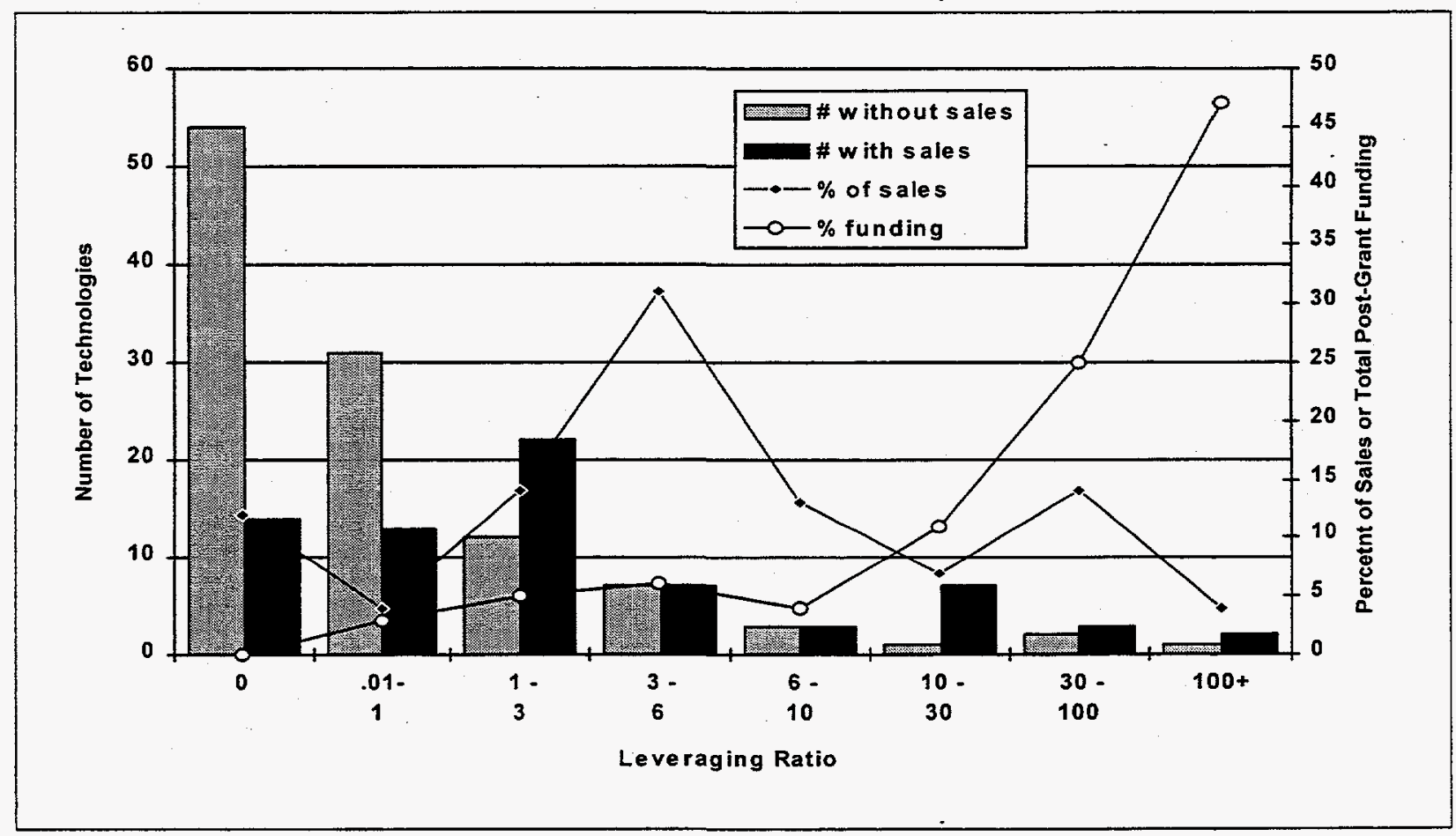

Fig. 6.4. Leverage ratios for all funds (constant 1994 dollars) raised by ERIP inventors after receipt of the ERIP Award.

(Sample: 182 cases with grants surveyed in 1995.) 
extensive development as well as a number of technologies which garnered substantial resources but were unsuccessful in the marketplace.

\subsection{SOURCES OF FINANCING FOR ERIP INVENTIONS}

To facilitate analysis of the sources of funding for ERIP inventions, eight types of financing were studied (see Table 6.1). This classification is used in Fig. 6.5 and 6.6 to characterize funding for ERIP inventors before application to ERIP, during the NIST approval process, after NIST approval but before the grant, and after the receipt of ERIP grants. This analysis, which was conducted for those with and without sales, excludes all ERIP grants, non-financial support, and short-term debt funding. Appendix C, Table C.3 provides the data from which Fig. 6.5 and 6.6 were derived.

Table 6.1. Classification of Funding Sources

\begin{tabular}{|c|c|}
\hline & NTERNAL SOURCES \\
\hline Personal & $\begin{array}{l}\text { - inventor's own savings } \\
\text { - friends and relatives } \\
\text { - funds from the development team } \\
\text { - private stock offerings }\end{array}$ \\
\hline Nonfinancial & $\begin{array}{l}\text { - sweat equity } \\
\text { - in-kind contributions of customers or suppliers }\end{array}$ \\
\hline Corporate & $\begin{array}{l}\text { - revenue generated through sales or royalties of the ERIP technology } \\
\text { - internal funds from other sources of revenue } \\
\text { - loans from customers or suppliers }\end{array}$ \\
\hline & EXTERNAL SOURCES \\
\hline Commercial & $\begin{array}{l}\text { - R\&D limited partnerships } \\
\text { - venture capital firms } \\
\text { - other outside investors } \\
\end{array}$ \\
\hline $\begin{array}{l}\text { Public Stock } \\
\text { Offerings }\end{array}$ & - stock offerings \\
\hline Lending Institutions & $\begin{array}{l}\text { - long-term loans to cover development costs, real estate purchases, } \\
\text { etc. } \\
\text { - short-term loans to cover inventory, etc. }\end{array}$ \\
\hline $\begin{array}{l}\text { State and local } \\
\text { Agencies }\end{array}$ & $\begin{array}{l}\text { - state and local grants and R\&D contracts } \\
\text { - loans from state and local agencies }\end{array}$ \\
\hline Federal Agencies: & $\begin{array}{l}\text { - federal agency R\&D contracts and grants } \\
\text { - loans from federal agencies }\end{array}$ \\
\hline
\end{tabular}




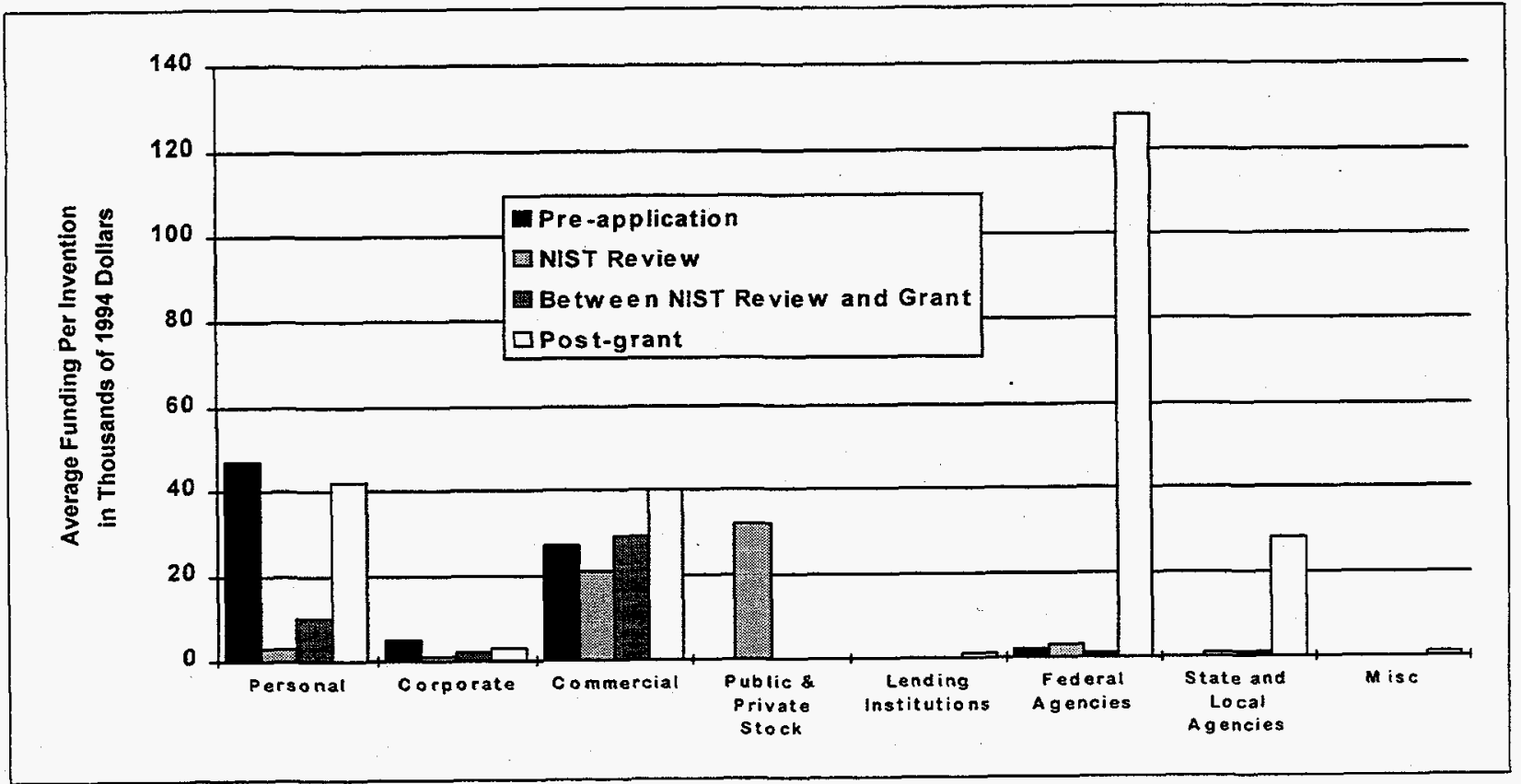

Fig. 6.5. Funding sources for ERIP inventions without sales. (Source: 111 grant recipients without sales surveyed in 1995.)

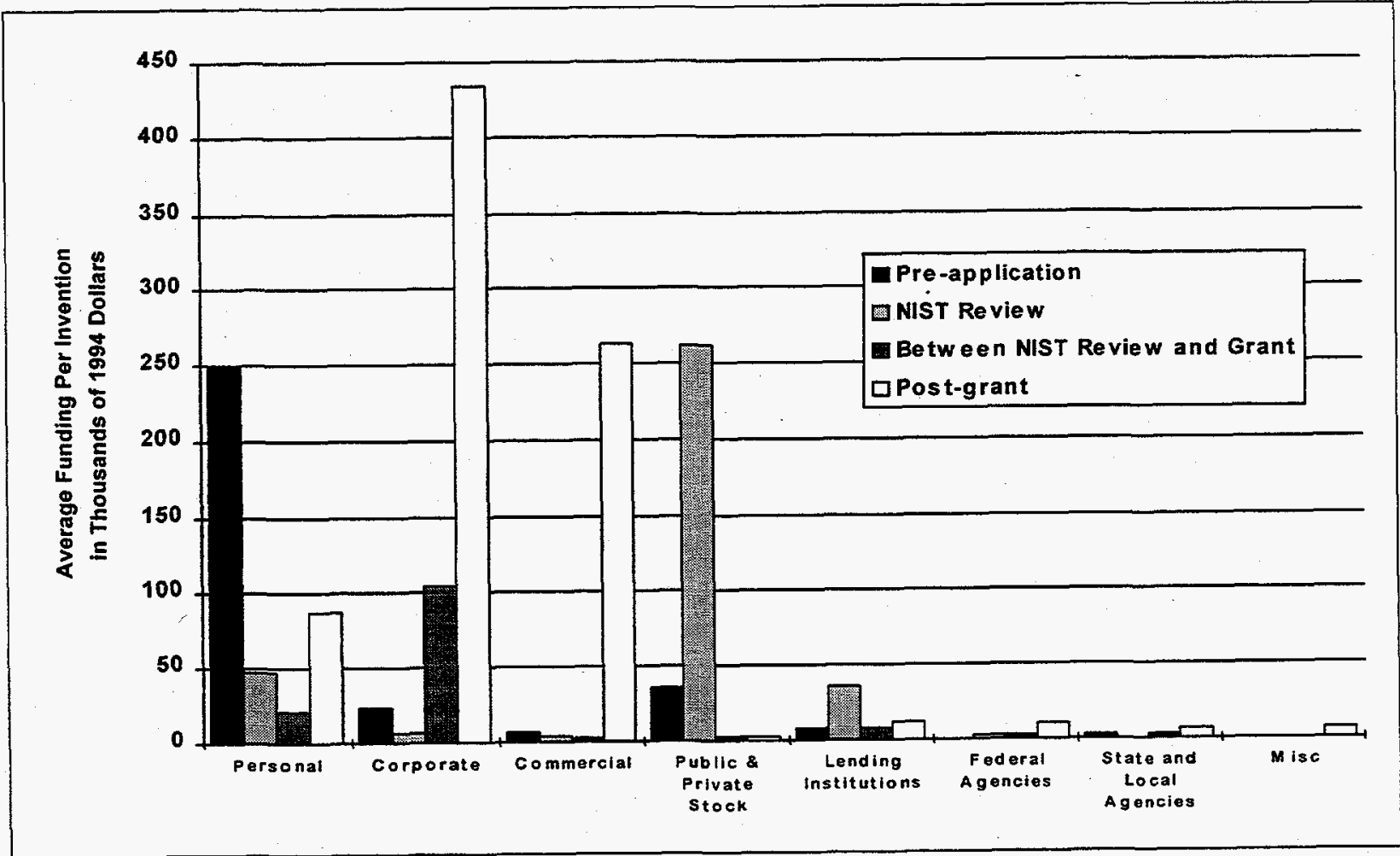

Fig. 6.6. Funding sources for ERIP inventions with sales. (Source: 71 grant recipients with sales surveyed in 1995.) 
The data in Fig. 6.5 is not entirely representative of ERIP technologies without sales, because $40 \%$ of the participants shown in Fig. 6.5 were part of the subsample of inventions identified as having the greatest near-term sales potential. As a result, these data over-represent those inventions in the later stages of development and those that have been more successful, and they probably overstate the funds raised by the typical ERIP tecnology without sales. Despite this bias, technologies that have entered the market have acquired considerably greater funding than those that have not yet had sales. This holds true in aggregate and for each of the eight types of funding except government support.

Inventions that have achieved sales have drawn upon different funding sources than inventions without sales. In particular, Fig. 6.6 suggests that success in the market goes to inventors who invest personal resources and raise significant amounts of corporate and commercial money, including funds from private and public stock offerings.

Before application to NIST, inventors who eventually achieved sales applied five times more personal funding (from their own funds, family and friends) than inventors who have not entered the market. What is perhaps more surprising is the level of continued reliance on personal sources of funding by both successful and unsuccessful inventors even after entry into the program. The persistence of personal sources of funding is illustrated by the fact that $28 \%$ of the inventors without sales and $27 \%$ of those with sales invested personal funds in their ERIP technology after receipt of an ERIP grant. Anecdotal evidence suggests that this is due in part to the unwillingness of many ERIP inventors to relinquish control of their inventions, which is a frequent outcome of licensing and venture capital negotiations.

Corporate funding, averaging $\$ 434,000$, was acquired after receipt of ERIP grants, by $27 \%$ of the ERIP technologies with sales. On average, the 71 grant recipients with sales surveyed in 1995 received a total investment over the life of the technology of $\$ 569,000$ from corporate sources. This makes corporate funding, on average, the single most important source of funding for ERIP technologies with sales. By contrast, technologies without sales received very little support form corporate sources, averaging $\$ 8,000$ before the grant and $\$ 3,000$ afterwards.

Commercial funding (e.g., R\&D limited partnerships, venture capital funds, and other outside investors), averaged $\$ 264,000$ during the post-grant period for ERIP technologies with sales. Commercial funding also provided important post-grant support for many ERIP technologies without sales, but the magnitude of funding was much lower, averaging $\$ 40,000$.

Grants and contracts with other public programs after the receipt of the ERIP award are relatively unimportant for those inventors who have successfully reached the market. Only $3 \%$ of ERIP inventors who enter the market obtain other federal grants or federal contracts subsequent to the ERIP award; this amounts 
to less than $1 \%$ of overall funding after receipt of the ERIP grant. State and local grants after the ERIP grant are also not significant for inventors with sales; only $4 \%$ have received this type of funding, and it represents less than $1 \%$ of funding during this period.

For some ERIP inventors without sales, however, the picture is quite different. ERIP inventions with no sales have, on average, received more than five times as much support from other public sources as inventions with sales. Four inventors are largely responsible for this post-grant public funding. One of these received over $\$ 800,000$ to develop an innovative pipeline technology; another amassed $\$ 8.2$ million (in 1994 dollars) in federal contracts and grants to develop a system for fossil fuel power plants. Seven percent of ERIP inventors without sales also acquired state or local funding, amounting to $11 \%$ of total post-grant funding.

In addition to equity capital and long-term bank loans, some ERIP inventors employ debt financing. One ERIP inventor with sales obtained a federally guaranteed loan before application to ERIP, while another acquired a state guaranteed loan after receipt of the ERIP grant. These sources together represent less than $2 \%$ of average total funding for ERIP inventors with sales. Three inventors with sales reported substantial use of private sector loans after receipt of the ERIP grant; these loans represent less than $3 \%$ of average postgrant funding.

Throughout the innovation development process, lending institutions are not commonly used by ERIP inventors. After receipt of the ERIP grant, loans from commercial banking institutions have been utilized by only $7 \%$ of the inventions with sales. Funds from lending institutions go virtually unused by ERIP inventors without sales, perhaps because such funds are difficult to secure during product development stages.

In aggregate, the 182 inventions with grants for which current financing data are available raised a total of $\$ 32.7$ million before application to ERIP, $\$ 32.0$ million during the grant approval process, $\$ 15.0$ million after grant approval but before receipt of the ERIP grant, and $\$ 85.4$ million after receipt of the ERIP grant. These figures are undoubtedly low estimates for the Program as a whole because of missing data and the presence of a significant number of young technologies in the current sample. Technologies with grants that have been sampled in previous years but which were not captured by the current sample design have accumulated an additional total of $\$ 76.5$ million before application to ERIP, $\$ 8.9$ million during the grant approval process, $\$ 10.2$ million after grant approval but before receipt of the ERIP grant, and $\$ 60.9$ million after receipt of the ERIP award. Thus, for the program as a whole, evaluations to date have enumerated $\$ 146.3$ million in funds raised by ERIP inventors after receipt of their ERIP grant ( $\$ 85.4$ million from the current evaluation and $\$ 60.9$ million form inventors included in previous evaluations). Since grants through 
1994 have totaled $\$ 47.5$ million, this results in a leveraging ratio of 3.1 ; that is, $\$ 3.1$ raised after the ERIP grant is received, for every dollar provided in grants.

In addition to financial support, ERIP participants have sustained the development of their technologies by the application of sweat equity as well as in-kind contributions from their suppliers, customers, and the communities in which they live. While the value of this sweat equity is difficult to establish, there is a considerable commitment of personal time by ERIP participants which in some cases represents several years of uncompensated labor. In-kind, non-financial support has come from diverse sources. Some ERIP participants have received raw materials and advice from companies in their industries. Others have been provided access to laboratories or machine shops at universities. The dollar value of the non-financial support received is typically less than $\$ 5,000$, but can come at a critical time during the development of the technology.

\subsection{IMPACT OF ERIP GRANTS ON PRIVATE SECTOR CAPITAL MARKETS}

Government programs which sponsor technology commercialization seek to trigger capital markets to invest in their sponsored technologies, so that small seed investments may be leveraged to achieve a substantial "bang-for-the-buck." This triggering may be prompted by ERIP as the result of 1) consulting advice about marketing, managerial techniques, funding sources, and business strategy provided by participation in the Commercialization Planning Workshops, 2) the signaling value of the NIST review and the ERIP grant, and 3) appropriately timed small grants which might help inventors surmount specific developmental hurdles. This section examines the impact of the ERIP grant as a catalytic event which can trigger private sector capital markets.

For the purposes of this evaluation, private sector capital markets include sources of equity and nonequity funding from outside the ERIP participant's company. Sources of equity funding include venture capital firms; joint ventures; equity investments by customers, suppliers, and licensees; venture partnerships; R\&D limited partnerships; independent investors; and both private and public stock offerings. Since private stock offerings may attract independent investors and venture capital, private stock was included in this definition of outside private capital markets even though a portion of funds in this category are from personal and internal corporate sources.

Excluded from this definition of private sector capital are personal sources, funds acquired from within the management team, internal funds from retained earnings generated either by the ERIP technology or other business lines, and public sector funding. Sources of non-equity funding from outside the ERIP firm, such as grants from private agencies, contracts for services, and long-term bank loans, are also excluded. 
Figure 6.7 illustrates the magnitude of post-award investment from these private sector capital markets. It indicates that the majority of ERIP technologies have not reported the use of private sector capital after the receipt of their ERIP grants. Specifically, 94 of the 111 inventions (85\%) without sales and 52 of 71 technologies (73\%) with sales report no post-grant private sector funding. As with sales, employment, and fund-raising in general, a small number of inventors are responsible for the vast majority of the impacts. In this case, seven technologies are responsible for $85 \%$ of all the post-grant private sector capital invested in ERIP technologies from sources outside of the ERIP companies.

One surprising finding shown in Fig. 6.7 is the proportion of overall sales volume generated by technologies that did not attract the involvement of private sector capital markets. The 52 grant recipients that have brought their technologies to market without any post-grant private sector capital, were responsible for $58 \%$ of total sales. At the other extreme, ERIP technologies with a post-award private sector leveraging ratio of 3.0 or greater represent $85 \%$ of all funding of this type, but only $7 \%$ of sales. Thus, there is minimal overlap between the inventors who are most successful at raising private sector capital from outside sources, and those that have experienced the greatest sales. ${ }^{1}$

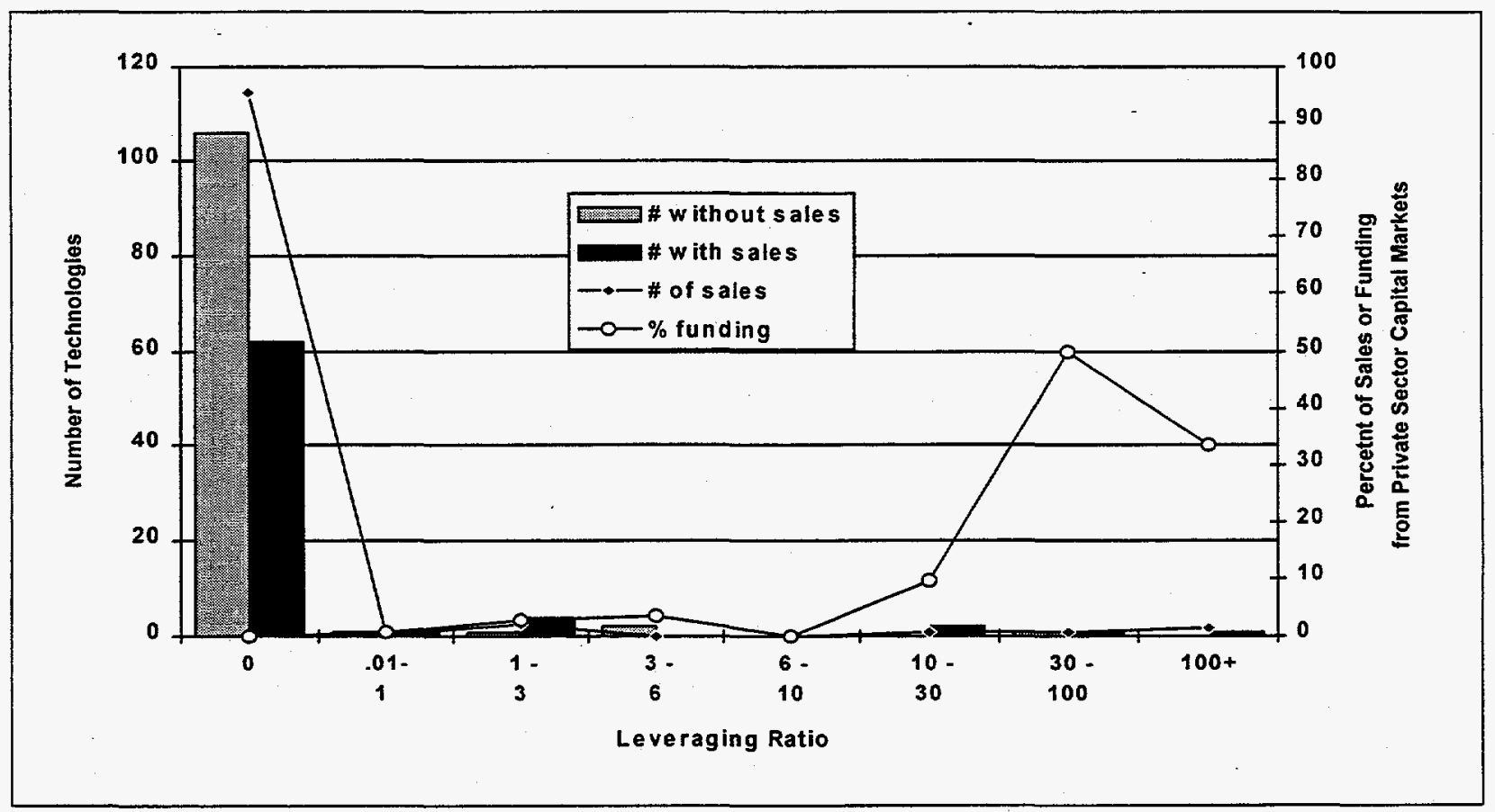

Fig. 6.7. Post-award use of private sector capital markets.

(Source: 182 grant recipients surveyed in 1995.)

\footnotetext{
${ }^{1}$ This pattern is somewhat exaggerated because of missing fund-raising data for several ERIP technologies that have been successfully marketed through licensees and where the full magnitude of investment costs may not have been reported by the ERIP inventors.
} 
These factors suggest that access to private sector capital often either remains relatively unavailable to ERIP participants after receipt of the ERIP award, or that ERIP participants have deemed access to private sector capital to be undesirable or unnecessary. Clearly, ERIP participants have found routes to commercial success that do not necessarily involve extensive use of private sector capital markets.

\subsection{THE ERIP GRANT AND ACQUISITION OF NON-ERIP FUNDING}

Most ERIP technologies, including $58 \%$ of those without sales and $80 \%$ of those with sales, have acquired at least some post-grant funding. The magnitude of this funding is generally less than that of the ERIP grant for those without sales, and greater than the grant for those with sales. Both in overall funding and in each of the specific funding categories, a few of technologies are responsible for the great majority of funding. For instance, in terms of post-grant funding:

- eight technologies accumulated $72 \%$ of total funding;

- three technologies acquired $88 \%$ of public sector funding (including grants from federal, state, and local agencies, contracts with federal agencies, and federal, state, and local guaranteed loans);

- five technologies were responsible for $92 \%$ of internal development funding (including retained earnings from sales of ERIP technologies, funds from non-ERIP product sales, in-house R\&D funds, and funds derived from private sector contracting);

- seven technologies accounted for $85 \%$ of funding from private sector capital markets (defined in Section 6.4) and;

- ten technologies were responsible for $77 \%$ of personal funding (including the inventor's own savings, friends and relatives, funds from the development team, and private stock offerings).

These findings indicate that many sources of funding, especially private sector capital markets remain largely untapped by ERIP grantees after receipt of the ERIP grant.

The ERIP grant recipients tend to be specialists rather than generalists in terms of the sources of funding they obtain. Those technologies receiving substantial internal development funding, for instance, typically do not acquire substantial amounts of follow-on funding from public sector sources. This is the reason why the distribution of overall funding is more even than that for any of the more specific funding sources.

While only a small subset of ERIP technologies have been highly successful in fund raising, qualitative information suggests that ERIP played a critical role in helping some number of these 
technologies surmount barriers early in development, and ultimately reach a stage in which subsequent fund raising could be based on business performance. Identifying the nature of this influence is essential to understanding the degree of impact of ERIP on subsequent fund-raising success. 


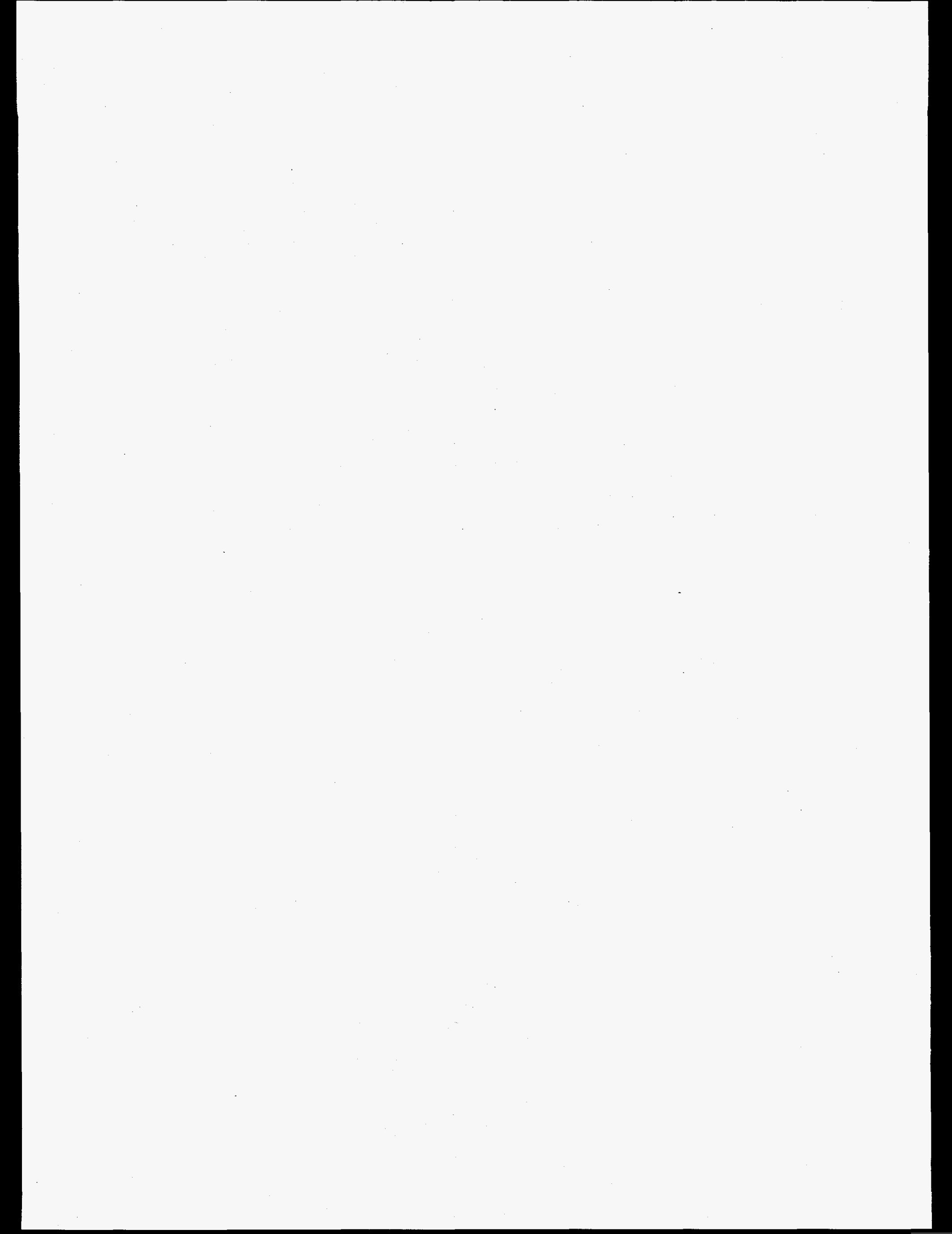




\section{ENERGY SAVINGS AND ENVIRONMENTAL BENEFITS}

The technologies supported by the Energy-Related Inventions Program offer a wide array of potential energy and environmental benefits. Some of the technologies deal with the production and distribution of non-renewable energy - e.g., technologies related to oil drilling, coal mining, electricity transmission, and natural gas distribution. Others are renewable energy technologies - e.g., advances in the design of solar collectors and windmills. The majority of the technologies, however, offer potential improvements in the end-use efficiency of energy, which in turn result in reduced emissions of greenhouse gases and other environmental benefits. Energy-efficient technologies are particularly prominent among the most successful of the inventions supported by the Program.

\subsection{THE RANGE OF ERIP TECHNOLOGY BENEFITS}

Respondents to the 1995 ERIP evaluation questionnaire were asked to describe the features of their ERIP technologies that represent benefits to users or to the public. The results are summarized in Table 7.1.

Table 7.1. ERIP Technology Benefits to Users and the Public

\begin{tabular}{|c|c|c|c|c|c|}
\hline Benefits to Users or Public & $\begin{array}{l}\text { Percent of } \\
\text { Promising } \\
\text { Inventions }\end{array}$ & $\begin{array}{l}\text { Percent of } \\
\text { Other } \\
\text { Inventions }\end{array}$ & $\begin{array}{l}\text { Percent of } \\
\text { Inventions } \\
\text { with Sales }\end{array}$ & $\begin{array}{l}\text { Percent of } \\
\text { Inventions } \\
\text { without } \\
\text { Sales }\end{array}$ & $\begin{array}{l}\text { percent of } \\
\text { Hentap } \\
\text { Inventions }\end{array}$ \\
\hline $\begin{array}{l}\text { Energy Efficiency } \\
\text { Improvements }\end{array}$ & 91.0 & 73.7 & 92.0 & 77.0 & 76.5 \\
\hline Pollution Reduction & 71.8 & 61.7 & 67.0 & 60.1 & 63.3 \\
\hline $\begin{array}{l}\text { Non-Renewable Energy } \\
\text { Production }\end{array}$ & 21.8 & 27.8 & 23.0 & 27.8 & 26.8 \\
\hline Waste Reduction & 16.7 & 27.1 & 18.0 & 19.1 & 25.4 \\
\hline Renewable Energy Production & 11.5 & 19.5 & 10.0 & 18.0 & 18.2 \\
\hline Other & 76.9 & 62.4 & 7.5 .0 & 61.7 & 64.7 \\
\hline
\end{tabular}

* To calculate each of these percentages, the percent of promising inventions was multiplied by $98 / 609$ and the percent of other inventions was multiplied by $511 / 609$, and the two products were added. 
Of the five specific types of energy and environmental benefits listed on the questionnaire, energy efficiency improvements and pollution reduction were cited most frequently (by $77 \%$ and $63 \%$ of the inventors, respectively). Non-renewable energy production and waste reduction benefits were also cited by more than $25 \%$ of the inventors. In addition, respondents to our survey indicated that $65 \%$ of the ERIP inventions are associated with "other" benefits. These include quality or performance improvements such as increased reliability and durability, and the reduction of manufacturing costs through labor-saving devices and reduced material requirements.

Of particular note in the table are some important differences between inventions with and without sales. Renewable energy production technologies are more heavily represented (18\%) in the inventions without sales compared to inventions with sales $(10 \%)$. In both cases renewable inventions are less than half the number of non-renewable inventions - $28 \%$ without sales and $23 \%$ with sales. These findings point to the difficult market faced today by renewable energy production technologies. Another point of interest is energy efficiency improvements. Almost all (92\%) of the inventions with sales promise some sort of improvements, while a lesser but still very substantial three-fourths (77\%) of the inventions without sales claim efficiency improvements. Overall, the results in Table 7.1 indicate a market preference for incremental solutions to energy and environmental issues that concentrate on improved energy efficiency rather than greater production and on reducing pollution rather than reducing waste.

\subsection{ENERGY SAVINGS OF FIVE ERIP-SUPPORTED TECHNOLOGIES}

\subsubsection{Methodology}

The amount of energy saved by the introduction of a new technology is difficult to estimate. One must consider a wide range of factors, including:

- the energy consumed by technologies that the new technology has displaced;

- any changes in the energy efficiency of the new technology over the lifetime of its operation; and

- any differences in the embodied energy required to produce the new technology and the technologies that are displaced.

Because of these complexities, it was not feasible to assess the energy saved by all of the ERIPsupported technologies that have entered the market. Instead, we examined the 15 ERIP-supported 
technologies that had achieved the greatest dollar value of cumulative sales through $1994^{1}$, under the assumption that these represent the technologies that are likely to have generated the greatest energy benefits. Each of these 15 technologies was examined to assess the feasibility of producing an estimate of energy savings based on available documentation and resources to conduct the assessments. This process resulted in narrowing the analysis to five technologies. It is anticipated that future research will address the energy savings of some of the remaining technologies.

The five inventions examined in this chapter are the:

- Brandon replacement packing rings for steam turbines;

- Electronic Octane ${ }^{\circledR}$ controls for automotive engines;

- SolaRollß solar collector for swimming pools;

- System $100 \circledast$ control system for natural gas compressor stations; and

- Thermefficient-100® industrial water heater.

These five technologies accounted for $\$ 361.6$ million in cumulative sales through 1994 , which represents $44.9 \%$ of the sales of ERIP-supported technologies accumulated to date.

A similar set of steps was taken for each of these technologies to estimate their energy savings. First, existing documentation on the technology was reviewed, including the NIST technical evaluation and information from previous ORNL evaluations of the Program. Additional information on the technology was solicited from the inventor and/or the licensee, including recent sales of the technology, and information from secondary sources was compiled, such as statistics from the Energy Information Administration. Second, a detailed analysis of energy savings was prepared and sent to a researcher at ORNL with expertise in the field of the particular technology. The detailed analysis was then revised, based on comments by the expert. Third, the revised analysis was sent to the inventor and DOE for review. The analysis was then finalized based on feedback from these reviewers.

\subsubsection{Description of the Five ERIP Technologies}

The five inventions examined in this chapter are described below.

Brandon steam turbine packing rings. The steam turbine packing rings developed by Ronald $\mathrm{E}$. Brandon are a modification to existing turbine packing rings. Packing rings are installed at various locations between the turbine stationary parts and the rotating shaft to minimize steam leakages between stages and at places where the shaft protrudes out of the turbine cylinder (Fig. 7.1). The invention employs springs to

\footnotetext{
${ }^{1}$ The selection of technologies for detailed analysis of energy impacts was based on historic data (i.e., sales through 1990) because this information was all that was available when the detailed analyses were initiated. Only subsequently were sales data through 1994 available.
} 


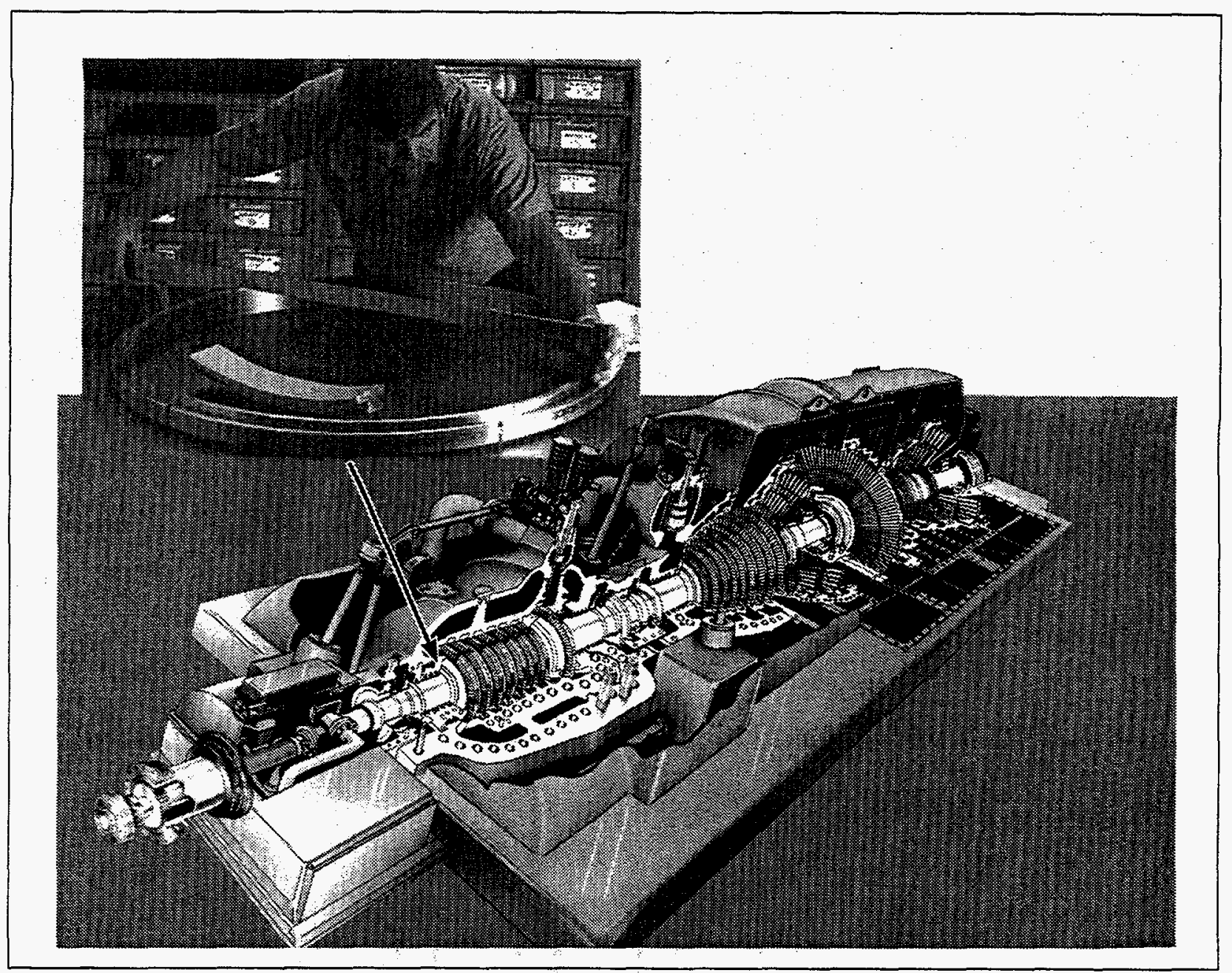

Fig. 7.1. Illustration of Brandon steam turbine packing rings.

keep the packing ring segments away from the turbine shaft during turbine start-up, when packing ring damage is most likely to occur.

The Brandon replacement packing rings prevent damage over time that occurs with conventional packing rings due to start-up, thermal distortion, and shaft vibration. The efficiency loss due to original packing rings is assumed to progress linearly from $0 \%$ to its maximum efficiency loss of $1 \%$ after 5 years. The Brandon steam packing rings prevent this gradual loss in efficiency.

Electronic Octane $\otimes$. Electronic Octane $\AA$, developed by John A. McDougal, is an ignition control system used in automotive internal combustion engines. This system senses the onset of predetonation ("knocking" or "pinging") caused by either carbon deposits, valve and spark timing, and/or wall temperatures, and provides feedback parameters in order to retard the spark advance as necessary in individual cylinders. Predetonation or knock, if allowed to continue, is destructive to automotive engines. 
The design of conventional vacuum control spark ignition systems overcompensates for the potential for knock in one or two individual cylinders by reducing the spark advance more than necessary for the rest of the cylinders that are operating normally. This reduces engine efficiency in order to prevent knocking in the one or two cylinders that require more control than the others. At a mid-RPM range of 2800 RPM, a $2.2 \%$ efficiency gain is expected for engines with the individual knock control system compared to a "global" knock control system. In addition, a lower octane can be used.

SolaRoll@. SolaRoll@ was developed by Michael F. Zinn. It is a solar collector that provides a low-cost method to provide solar heating to swimming pools. The majority of the pools having the SolaRoll@ system installed are heated by conventional natural gas or electric heat pump systems. SolaRoll@ is a flexible rubber tubing solar collector. The rubber components have a lifetime expectancy of 20 years or more. The SolaRoll@ product has a relatively high efficiency accompanied by a low relative cost per square foot of collector area. SolaRoll $\circledast$ is used in both in-ground and above-ground pools. The average pool in the U.S. will likely realize an annual reduction of $55 \%$ in heating costs. The use of a SolaRoll collector and associated equipment will result in annual energy savings of 42 million Btu for a pool heated with a conventional gas-fired system; the annual savings will be approximately 11 million Btu for a pool heated by a heat pump system.

System $100 \otimes$. System $100 \circledast$ was developed by Alex Rutshtein and Naum Staroselsky. The purpose of the System $100 \otimes$ control system is to permit the efficient use of large centrifugal and axial compressors employed in process applications such as refineries and gas transmission pipelines. System $100 \circledast$ allows a compressor to operate closer to its surge limit, increases stall protection, and generally enables the compressor to operate in a more efficient region. Prior to the System $100 \circledast$, the traditional control method used for compressors powering the natural gas flow on gas transmission pipelines was either a manual or the more common, two-function controller. The two-function controller regulates the blow-off valve (regulating pressure across the compressor) and the speed of the compressor drive independently, and must be detuned to prevent system oscillation. This reduces system efficiency, especially in high speed compressors. System $100 \circledast$ provides integrated control of compressor speed and output pressure, allowing the compressor to operate more efficiently. Energy savings, depending on the application, are typically in the $5 \%$ to $10 \%$ range, which translates to annual savings of approximately 23.5 million cubic feet of natural gas per unit installed.

Thermefficient-100®. Thermefficient- $100 \otimes$ was developed by Harry E. Wood and is a high efficiency gas-fired water heater that allows most of the total heat of combustion of the unit to be utilized (Fig. 7.2). A direct-contact heat exchanger using packed rings or a similar adaptation operates in a counterflow arrangement such that the combustion product's exhaust temperature is very close to the 


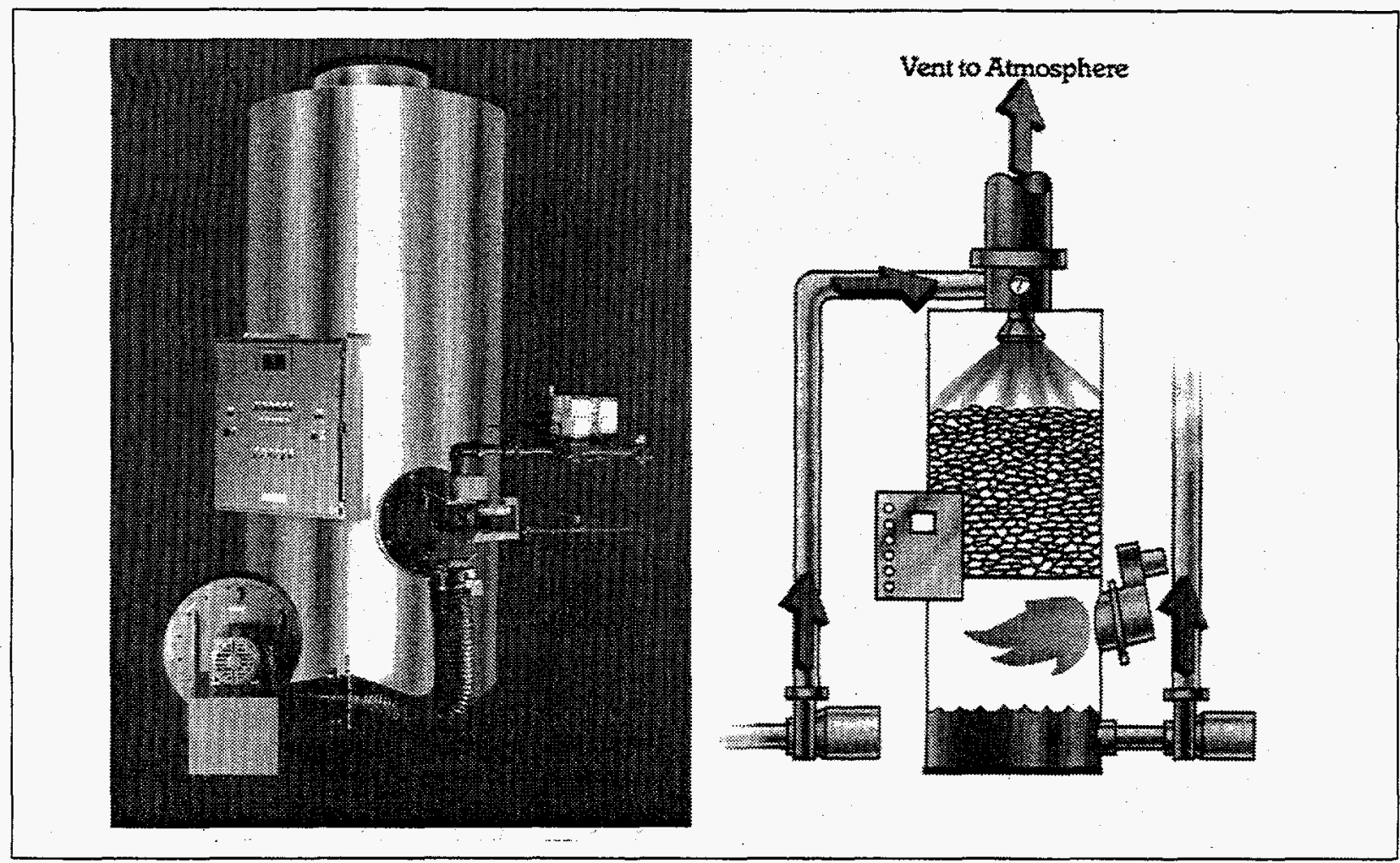

Fig. 7.2. Illustration of Thermefficient-100®.

temperature of the incoming water. In conventional water heaters the latent heat of vaporization of the combustion produced water is totally lost.

The Thermefficient- $100 \otimes$ system has a thermal efficiency close to $100 \%$ compared to approximately $70 \%$ for conventional water heaters. The design allows heated water to collect at the bottom of the water storage tank with no start-up time required for water temperature to increase to normal operating temperature. The Thermefficient- $100 \otimes$ system is very compact requiring only $32 \%$ of the floor space of a conventional water heater of equivalent capacity.

\subsubsection{Energy Consumption and Savings}

The annual energy savings and cumulative savings for sales of the five technologies is shown in Table 7.2. Annual energy savings represent the savings achieved in any particular year as a result of total sales of a technology through that year. Cumulative energy savings is the total of each year's energy savings through 1994. In total, it is estimated that these five technologies saved 0.58 Quads of energy between 1980 and 1994. In 1994 alone, it is estimated that these five technologies saved 0.116 Quads of energy. This is enough to meet the United States' energy requirements for 12 hours. 
Table 7.2. Energy Savings, in Trillions of Btu

\begin{tabular}{|c|c|c|c|c|c|c|}
\hline \multirow[b]{2}{*}{ Year } & \multicolumn{6}{|c|}{ Energy Savings (Btus X $10^{12}$ ) } \\
\hline & $\begin{array}{c}\text { Brandon } \\
\text { Packing } \\
\text { Rings }\end{array}$ & $\begin{array}{l}\text { Electronic } \\
\text { Octane } 8\end{array}$ & SolaRollB & $\begin{array}{c}\text { System } \\
100 \otimes\end{array}$ & $\begin{array}{c}\text { Therm- } \\
\text { efficient } \\
100 \otimes\end{array}$ & Total \\
\hline 1980 & NS & NS & 0.082 & 0.648 & NS & 0.730 \\
\hline 1981 & NS & NS & 0.279 & 1.585 & 0.152 & 2.016 \\
\hline 1982 & NS & NS & 0.498 & 2.593 & 0.313 & 3.404 \\
\hline 1983 & NS & NS & 0.726 & 4.058 & 0.525 & 5.309 \\
\hline 1984 & NS & 0.011 & 0.990 & 6.243 & 0.733 & 7.977 \\
\hline 1985 & NS & 0.414 & 1.219 & 9.580 & 0.966 & 12.179 \\
\hline 1986 & 0.022 & 1.492 & 1.417 & 13.638 & 1.250 & 17.819 \\
\hline 1987 & 0.244 & 3.064 & 1.588 & 17.839 & 1.519 & 24.254 \\
\hline 1988 & 1.666 & 4.370 & 1.754 & 22.930 & 1.734 & 32.454 \\
\hline 1989 & 4.324 & 5.753 & 1.894 & 28.740 & 2.133 & 42.844 \\
\hline 1990 & 8.654 & 6.775 & 2.060 & 35.991 & 2.686 & 56.166 \\
\hline 1991 & 13.967 & 7.165 & 2.142 & 43.242 & 3.362 & 69.878 \\
\hline 1992 & 20.229 & 7.570 & 2.230 & 50.493 & 4.204 & 84.726 \\
\hline 1993 & 26.486 & 7.646 & 2.334 & 58.200 & 5.326 & 99.992 \\
\hline 1994 & 33.166 & 7.611 & 2.446 & 66.340 & 6.448 & 116.011 \\
\hline Total & 108.758 & 51.867 & 21.659 & 362.120 & 31.350 & 575.754 \\
\hline
\end{tabular}

NS=No sales reported that year. 
The energy savings by fuel type for the Brandon replacement packing rings was accomplished by using the distribution of annual sales of the packing rings from 1986 through 1994, by primary fuel of the turbines fitted. It is assumed that turbines can be operated for a maximum of 8,760 hours per year at an average capacity of $75 \%$. The average size of turbine capacity in the U.S. of coal, natural gas, and oil units was utilized to complete the apportionment of total estimated energy savings (Energy Information Administration, 1991). The percentage of energy savings by fuel type for the packing rings is as follows:

- Coal - 78.7\%

- Natural gas - $9.0 \%$

- Oil- $12.3 \%$

These percentages multiplied by total energy savings for the packing rings in 1994 result in the following energy savings in trillion Btus: for coal-26.1, natural gas -2.98 , and oil -4.08 .

The Electronic Octane $B$ is utilized in eight automobile models. For each of these models, data were collected on sales by year. Annual mileage was assumed to be $55 \%$ city and $45 \%$ highway, and the total mileage driven each year, per auto, was assumed to be the average for all passenger cars that year. A survival rate was applied to account for normal scrappage. Energy savings is calculated by multiplying annual gasoline consumption by 0.0216 , which is the fraction of gasoline saved by Electronic Octane ${ }^{\circledR}$. Based on these calculations it is estimated that this ERIP technology saved approximately 7.61 trillion Btus of gasoline in 1994, which translates to 1.45 million barrels of gasoline, or 2.9 million barrels of oil.

The energy saved by SolaRoll $\otimes$ is estimated using the total square footage of the product sold by year between 1979 and 1994. Based on a model of swimming pool energy costs, it is assumed that SolaRoll $\circledast$ saves 0.0233 million Btu/sq $\mathrm{ft} /$ year for pools using electric heat pumps and 0.089 million Btu/sq $\mathrm{ft} /$ year for pools heated by natural gas. We assume that $70 \%$ of the square footage of SolaRollß is applied to gas-heated pools, and $30 \%$ to electrically heated pools. To determine the individual fuels saved by the displaced electricity, we assume that $60 \%$ of electricity is generated by coal, $8 \%$ by gas, and $2 \%$ by oil. Based on these assumptions, it is estimated that SolaRoll@ saved 2.45 trillion Btu of energy in 1994. These savings include 25,000 tons of coal, 3,042 barrels of oil, and 2,220,000 thousand cubic feet of natural gas.

The energy savings for System $100 \circledR$ was based on the number of units sold each year between 1980 and 1994. We assume that sales of the systems are evenly divided between natural gas-powered pipeline compressors (with average annual savings of 27.82 billion Btu per system) and steam-powered industrial compressors (with average annual savings of 20.21 billion Btu per system). Based on these assumptions it is estimated that System $100 \otimes$ installations to date saved 66.34 trillion Btus of natural gas in 1994. This savings amounted to $64,349,800$ thousand cubic feet of natural gas. 
Thermefficient-100® water heaters have increased in both hours of use and energy use per hour, since 1981 when they first entered the market. These changes are due to a trend toward consolidation in the industries using the hot water systems. The energy consumption of the Thermefficient-100® technology is calculated as the product of hours of usage per year (2,000 hours in 1981, rising by 200 hours/year to 4,000 hours of usage in 1991) and energy use per hour (4 million Btu in 1981, rising to 4.6 million Btu in 1988 and 7.0 million Btu in 1992). Conventional industrial water heaters are assumed to consume 1.43 times as much energy, based on their relative thermal efficiencies. The energy savings is then the difference between conventional use and Thermefficient-100@ use. Based on the methodology, the Thermefficient-100ß water heater saved 6.448 trillion Btus of natural gas in 1994. This translates into 6,254,230 thousand cubic feet of natural gas saved.

A summary of energy savings in 1994 by fuel type for the five technologies is presented in Table 7.3. The equivalent energy savings in trillion Btu's are presented in Table 7.4.

Table 7.3. Energy Savings by Fuel Type for Five Technologies in 1994

\begin{tabular}{|l|c|c|c|}
\hline \multirow{2}{*}{ Technology } & $\begin{array}{c}\text { Coal } \\
\text { (tons) }\end{array}$ & $\begin{array}{c}\text { Oil } \\
\text { (barrels) }\end{array}$ & $\begin{array}{c}\text { Natural gas } \\
\text { (KCF) }\end{array}$ \\
\hline Brandon packing rings & $1,262,589$ & 653,645 & $2,900,000$ \\
\hline Electronic Octane $®$ & - & $2,896,000$ & - \\
\hline SolaRoll@ & 25,231 & 3,042 & $2,220,000$ \\
\hline System $100 @$ & - & - & $64,349,800$ \\
\hline Thermefficient-100@ & - & - & $6,254,230$ \\
\hline Total & $1,287,820$ & $3,552,687$ & $75,724,030$ \\
\hline
\end{tabular}

KCF=thousand cubic feet.

Table 7.4. Energy Savings, in Trillions of Btu, in 1994

\begin{tabular}{|l|c|c|c|c|}
\hline \multicolumn{1}{|c|}{ Technology } & Coal & Oil & Gas & Total \\
\hline Brandon Packing Rings & 26.10 & 4.08 & 2.98 & 33.16 \\
\hline Electronic Octane $(B$ & - & 7.61 & - & 7.61 \\
\hline SolaRoll@ & 0.15 & 0.01 & 2.23 & $2.39^{\mathrm{a}}$ \\
\hline System $100 \otimes$ & - & - & 66.34 & 66.34 \\
\hline Thermefficient-100ß & - & - & 6.45 & 6.45 \\
\hline Total & 26.25 & 11.70 & 78.00 & 115.95 \\
\hline
\end{tabular}

aThe amount of 2.45 trillion Btus in Table 7.2 is the total amount of electricity saved by this invention. The 2.39 trillion Btus in this table is the amount of electricity generated by coal, oil and gas. Thus the difference between the two figures is electricity generated by nuclear and hydro. 


\subsubsection{Value of Energy Savings}

The value of the energy saved by each of the five technologies is dependent on the price of the particular fuel saved. The cost of energy saved by the Brandon replacement packing rings is priced by the cost of fossil fuels faced by electric utilities. The approximate cost of fossil fuel energy for an electric utility in 1994 is $\$ 1.53$ per million Btu (Energy Information Administration, 1996). Therefore, the value of the energy savings in 1994 for the turbine units having the Brandon rings installed between 1986 and 1994 is approximately \$51 million in 1994 dollars (33.166 trillion Btu X 1.53 \$/million Btu = 50.74 million dollars).

The value of the energy savings in 1994 for sales of autos reported to have the Electronic Octane $\otimes$ technology installed is estimated to be $\$ 71.3$ million in constant 1994 dollars. This value was calculated using the estimate of energy savings in gallons (1.45 million barrels of gasoline), times the average annual price of unleaded regular gasoline of $1.17 \$ / \mathrm{gal}$ (we used regular unleaded gasoline for most auto brands and premium unleaded gasoline for those automobile brands having high compression engines).

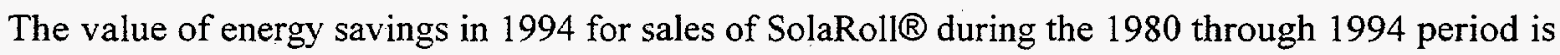
$\$ 27.6$ million in 1994 dollars. This value was based on an estimated annual savings of $\$ 253$ in heating costs, per pool, attributed to the use of SolaRoll@ (RSPEC, 1993). Further, cumulative sales figures indicate that in 1994 approximately 108,923 pools used SolaRoll@ $(\$ 253 /$ pool x 108,923 pools $=\$ 27.6$ million $)$.

The value of energy savings in 1994 for sales of System-100® for the 1980 through 1994 period equal $\$ 157.7$ million in constant 1994 dollars. This was calculated using a composite price of $\$ 2.45 /$ thousand cubic feet (KCF) of natural gas (Energy Information Administration, 1996) $\left(\$ 2.45 / \mathrm{KCF} \times 64.35 \times 10^{6} \mathrm{KCF}\right.$ $=\$ 157.7$ million).

The value of energy savings in 1994 for sales of Thermefficient- $100 \circledast$ units during the 1980 through the 1994 time period is $\$ 26.5$ million in constant 1994 dollars. This value was calculated using the 1994 estimate of energy savings in KCF of natural gas times the average annual price of natural gas [we used the average natural gas price for commercial and industrial users (Energy Information Administration, 1996)]. This calculation also takes into consideration the increase in hours of operation, per unit, from 2,000 hours/year in 1981 to 4000 hours/year in 1994 (6.254 x 10 $\mathrm{KCF} \times \$ 4.24 / \mathrm{KCF}=\$ 26.5 \mathrm{million})$. This increase in hours of operation is largely attributed to consolidation in the industries utilizing the hot water systems.

For the purposes of this analysis, we have estimated a very simple payback by calculating the time period over which the cumulative energy savings will be equivalent to the initial capital costs of the new technology. A more sophisticated payback calculation, which would take into account such factors as reduction of downtime, reduced operations \& maintenance costs and product longevity, cannot be calculated 
with the data available at this time. The value of energy savings and cost effectiveness (measured by payback period) for the five technologies is shown in Table 7.5. The value of the total 1994 energy savings for the technologies is $\$ 333.8$ million. The payback periods for the five technologies - calculated by dividing the cost of the new technology by the annual energy savings in 1994 dollars - range from 2 to 8.3 years.

Table 7.5. Value of Energy Savings in 1994

\begin{tabular}{|c|c|c|c|c|c|c|}
\hline & $\begin{array}{l}\text { Brandon } \\
\text { Packing } \\
\text { Rings }\end{array}$ & $\begin{array}{l}\text { Electronic } \\
\text { Octaneß }\end{array}$ & SolaRolle & $\begin{array}{c}\text { System } \\
100 \AA\end{array}$ & $\begin{array}{l}\text { Thermef- } \\
\text { ficient- } \\
100 B\end{array}$ & Total \\
\hline $\begin{array}{l}\text { Value of } 1994 \\
\text { energy savings (in } \\
\text { million } 1994 \$ \text { ) }\end{array}$ & 50.7 & 71.3 & 27.6 & 157.7 & 26.5 & 333.8 \\
\hline $\begin{array}{l}\text { Payback period } \\
\text { (yrs) }\end{array}$ & 3.51 & 3.91 & 8.3 & $2^{\mathrm{a}}$ & 4.68 & - \\
\hline
\end{tabular}

${ }^{a}$ Costs for this technology are difficult to estimate because of associated equipment costs. A payback period for a similar system was estimated to be under two years (Devlin, et al., 1992).

\subsection{REDUCTION OF GREENHOUSE GAS EMISSIONS}

Tables 7.6 and 7.7 present estimates of the reductions in emissions of carbon and methane in 1994 associated with the sales to date (1980-1994) of Brandon packing rings, Electronic Octane $($, SolaRoll®, System $100 \circledast$ and Thermefficient- $100 \circledast$. The base data for greenhouse gas emissions come from the Energy Information Administration (1995b), and energy use data required for the estimates come from the Energy Information Administration (1996).

The estimates of methane reductions are comprehensive for coal, but they do not include methane emissions associated with production, transmission, and distribution of natural gas. The bulk of methane emissions from natural gas occurs during those steps rather than during end use, and inclusion of reductions in those emissions as well would multiply the estimates in Table 7.6 by a factor of 135 .

In order to have a single yardstick by which reductions in greenhouse gas emissions can be compared, emissions of carbon and methane are often reported in terms of $\mathrm{CO}_{2}$ equivalents. The $\mathrm{CO}_{2}$ resulting from the emission of elemental carbon is calculated by multiplying units of carbon by 3.67 , the proportional difference in molecular weights. The factor for converting methane into $\mathrm{CO}_{2}$ equivalents is 35 , since methane has 35 times the warming potential of $\mathrm{CO}_{2}$. These reductions of $\mathrm{CO}_{2}$ equivalent emissions in 1994 (from sales during 1980-1994) are shown in Table 7.8. 
Table 7.6. Reduction in Carbon Emissions in 1994, in Metric Tons

\begin{tabular}{|l|c|c|c|c|}
\hline \multicolumn{1}{|c|}{} & Coal & Oil & Gas & Total \\
\hline Brandon Packing Rings & 671,031 & 84,538 & 43,121 & 798,690 \\
\hline Electronic Octane & - & 163,082 & - & 163,082 \\
\hline SolaRoll@ & 3,857 & 207 & 32,268 & 36,332 \\
\hline System 100@ & - & - & 959,940 & 959,940 \\
\hline Thermefficient-100® & - & - & 93,332 & 93,332 \\
\hline \hline Total & 674,888 & 232,607 & $1,128,661$ & $2,051,376$ \\
\hline
\end{tabular}

Table 7.7. Reduction in Methane Emissions in 1994, in Metric Tons (excluding emissions in associated production, transmission, and distribution)

\begin{tabular}{|l|c|c|c|c|}
\hline & Coal & Oil & Gas & Total \\
\hline Brandon Packing Rings & 17.4 & - & 3.2 & 20.6 \\
\hline Electronic Octane ${ }^{8}$ & - & - & - & - \\
\hline SolaRoll@ & 0.1 & - & 2.5 & 2.6 \\
\hline System $100 \circledR$ & - & - & 72.3 & 72.3 \\
\hline Thermefficient-100® & - & - & 7.0 & 7.0 \\
\hline \hline Total & 17.5 & - & 85.0 & 102.5 \\
\hline
\end{tabular}

Table 7.8. Reductions in Emissions of $\mathrm{CO}_{2}$ Equivalents from Carbon and Methane

\begin{tabular}{|l|c|c|c|}
\hline \multicolumn{1}{|c|}{$\begin{array}{c}\text { Component } \\
\text { Carbon }\end{array}$} & $\begin{array}{c}\text { Factor Converting to } \\
\mathbf{C O}_{2} \text { Equivalents }\end{array}$ & $\begin{array}{c}\text { Metric Tons of CO } \\
\text { Equivalent }\end{array}$ \\
\hline Methane & $2,036,156$ & 3.67 & $7,472,693$ \\
\hline Total & 102.51 & 35 & 3,588 \\
\hline
\end{tabular}


In 1994, the five ERIP technologies reduced carbon emissions by an estimated 2.1 million metric tons and methane emissions by an estimated 102.5 metric tons. This results in a total reduction of the equivalent of approximately 7.5 million metric tons of $\mathrm{CO}_{2}$. This reduction in greenhouse gas emissions is equivalent to removing 2.3 million cars from the U.S. roadways. ${ }^{2}$

${ }^{2}$ This calculation is based on the following statistics: the transportation sector in the U.S. produced 446 million metric tons of carbon emissions in $1994 ; 39.1 \%$ of these emissions were the result of the 190.4 million passenger cars operating in the U.S. (U.S. Department of Transportation, Bureau of Transportation Statistics, 1994, pages 17 and 152). Thus, each passenger car produces 0.913 metric tons of carbon emissions each year. 



\section{PARTICIPANT PERCEPTIONS AND EVALUATION CONCLUSIONS}

\subsection{PARTICIPANT PERCEPTIONS}

The 1995 ERIP evaluation questionnaire asked inventors to rate each of six types of ERIP assistance based on its helpfulness to the commercialization of their technology. The average rating given to each type of assistance is presented in Table 8.1, where "not at all helpful" is given a rating of 1 , and "extremely helpful" is given a rating of 10 . These ratings are discussed below in conjunction with responses to the openended questions that concluded the questionnaire, specifically: "What other types of assistance from the ERIP program would have helped you to commercialize your ERIP technology?" and "In your own words, how did the ERIP program help you or your company?"

Inventors indicated that the grant was by far the most valuable type of assistance provided by ERIP. This is especially true of inventors who have not yet reached the marketplace with their ERIP technology. As one inventor put it, "the major problem in start-up commercialization is raising capital. In a sense, fund raising serves as an entrepreneurial filter." Many inventors underscored the critical role that ERIP funding played:

- "Without the funding from the ERIP program we could not have made the improvements and have obtained the subsequent patent to stay in business!"

- "Our DOE grant provided critical financial support. Without this support, we likely would not have been able to progress beyond feasibility studies."

- "ERIP provided the 'shot in the arm' to get the technology going. The technology would never have existed without ERIP help."

- "ERIP helped by providing the financial means to get started--perhaps the most difficult challenge for any operation like this. . I would not be doing this business if not for ERIP!"

- "ERIP got us started. We now employ 13 people."

- "The ERIP program provided the essential funds that made it possible to develop the invention and concept into prototype operating systems."

Many inventors noted that a larger grant would have been helpful. Some inventors offered that the ERIP grant is insufficient to acquire the equipment needed and to pay for the market development work. On the other hand, receipt of ERIP has also helped some inventors raise additional resources. As one inventor put it, "ERIP supplied the initial funds to get started. It also provided credibility to raise funds on our own 
Table 8.1. Participant Perceptions of ERIP Services

\begin{tabular}{|l|c|}
\hline \multicolumn{1}{|c|}{ Assistance to Inventors } & \multicolumn{1}{|c|}{$\begin{array}{c}\text { Average Ratings of } \\
\text { All ERIP } \\
\text { Inventors }\end{array}$} \\
\hline Grant
\end{tabular}

${ }^{3}$ To caiculate each of these weighted averages, the percent of promising inventions was multiplied by $98 / 450$, the percent of other inventions was multiplied by $352 / 450$, and the products were added.

${ }^{b}$ Respondents were asked to skip this question if no DOE grant was received.

once we did get started." Similarly, according to another inventor, "Our product's association with the program gave it instant credibility with potential customers and investors."

Several inventors complained about the time they invested in applying for ERIP funds, only to be refused. Others complained about the time delays associated with processing the grant. According to one inventor, after being accepted into the program, it took one and a half years to then receive a grant, despite promises from his DOE Invention Coordinator that it would only take a few months. The length of time between application and grant receipt has been a source of inventor complaints during each of our previous program evaluations. Partly as a result of these complaints, the Program has recently reduced its processing time by accelerating both the NIST technical review and the DOE grant processing time.

The second most highly rated type of ERIP assistance was the technical evaluation provided by NIST. According to one inventor, the technical review helped to "authenticate the benefits" of his technology. In the words of another inventor, "It really helped to have a good technical review in writing. It was good to have a document with Ph.D.'s names on it that says 'This is sound. It will work." That gave us credibility that helped to get license agreements."

ERIP's Commercialization Planning Workshop was also highly rated, especially by inventors who have succeeded with their technologies. To at least one inventor, the Workshop "was the most enduring help. It probably turned out to be worth more than the money." In the words of another inventor, "The workshop 
was fantastic. It is probably the most intensive learning program I have been involved in. It made us think about what is out there in terms of the potential for our company and our technology. I can not say enough about the workshop. It is the best help people can get in commercializing a new technology."

Assistance with raising funds and with sales or licensing due to the credibility associated with participation in ERIP were given ratings of only 3.7 and 3.2, respectively. The ratings were much higher for inventors with ERIP technologies that have had sales, many of whom underscored the value of these two types of assistance in describing the benefits they received from the Program.

Assistance with networking and other benefits provided by DOE Invention Coordinators received a similarly low rating relative to the value of ERIP's grants, technical evaluation, and Commercialization Planning Workshop. Yet many inventors suggested that networking assistance could have been quite helpful to them. "The ERIP program should consider interfacing with other government agencies that may be able to assist in commercialization." Helping inventions qualify for federal procurements was also noted by several respondents. "I could have benefited from networking with various other governmental agencies that could benefit from the technology such as the military and police." Inclusion of technologies in DOE publications and conferences was also suggested as a means of publicizing ERIP inventions.

A review of the open-ended questions identified a second area of ERIP assistance that inventors would like to see strengthened: help with marketing. "ERIP needs to give more marketing support. . it is so important." The following types of marketing assistance were suggested by inventors: help assessing market opportunities, making business contacts, identifying export markets, and in general, assisting "with the business and people part."

The open-ended questions identified another general category of ERIP assistance that was not specified on the evaluation questionnaire: moral support. For instance, one inventor noted that the intangible (moral) support structure was very helpful." According to another inventor, "When one goes out to get an innovation he is alone. Moral support is a big help. ERIP provided encouragement. . it is very important."

Finally, a review of answers to the open-ended questions underscored one of the evaluation's ongoing challenges-the fact that ERIP technologies often change hands and the person who originally applied for Program support may no longer be involved with it. As result of this inevitable (and often highly beneficial) transitioning, our evaluation questionnaire is sometimes completed by an entrepreneur who has limited knowledge of the technology's history, and knows nothing about the involvement of DOE. Receipt of a small grant to develop a product that has since generated millions of dollars of sales may seem inconsequential to this individual, in hindsight. But when it arrived, the grant and other Program support may have sustained the technology through a vulnerable period when personal and informal funding sources had run dry, and other financial resources were beyond the inventor's reach. 


\subsection{RECEIPT OF AN ERIP GRANT, GRANT SIZE, AND THE PERFORMANCE OF ERIP TECHNOLOGIES}

This section analyzes the distribution and size of grants awarded by the ERIP Program. Although many ERIP applicants seek technical assistance for validation of their technologies through the review process, and some anticipate commercialization counseling after acceptance into the ERIP Program, the ERIP grant is considered by most applicants to be the most important benefit provided by the Program.

With the data collected for the current and past evaluations of ERIP, it is possible to assess whether the incidence or size of the ERIP awards has had an impact on the level of success of ERIP technologies. A basic principle of technological nurturance is that funding is often in short supply for technologies under development, and that relatively small amounts of funding can sometime be critical. Little research, however, has investigated the magnitude of financial assistance from government programs required to foster the commercial success of the funded technologies.

To date, 475 or ( $78 \%$ of the 609 inventions that were recommended by NIST to participate in the Program received a grant from DOE. ERIP applicants who are recommended by NIST to DOE for funding fail to receive funding for a number of reasons. In some cases, grants are not awarded because technical development is complete and the technology has already entered the market. Due to the time lag between application to NIST and
The development of a high-efficiency dehumidifier/airconditioner by Khanh Dinh illustrates the important role that ERIP funding has played in the transition of small businesses from fledgling companies to thriving enterprises that add significantly to a local area's employment base.

Khanh Dinh invented the heat pipe system for high-efficiency dehumidification and air conditioning in the early 1980s. The invention involves a system of heat pipes that are placed in the airducts of an air-conditioning system to transfer heat between the return and supply ducts, thereby increasing the dehumidification capability of the system. By passively precooling the return air and reheating the supply air, the heat pipes allow the use of a smaller compressor and the suppression of the conventional reheat. These features lead to significant energy savings.

Mr. Dinh developed and tested small-scale prototypes of the heat pipe system in the mid $1980 \mathrm{~s}$ and patented his invention in 1986. During these early years, financial resources to develop the technology were difficult to acquire. In 1991 he received a grant for $\$ 99,500$ from the Energy-Related Inventions Program, which enabled him to complete a program of engineering analysis that led to significant design improvements. With improved prototype in hand, Mr. Dinh achieved his first major sales in 1992. Each year since then, sales have grown by $20-30 \%$, and in 1995 they surpassed $\$ 3$ million. His licensing partners now include General Electric and Mitsubishi Cable of Japan, and units are currently in operation in a wide range of applications including libraries, museums, hospitals, supermarkets, and restaurants around the world.

From a company of only 6 employees in 1984. Heat Pipe Technology, Inc., located in Alachua. Florida, now has 48 employees on its payroll and has sales representative in 48 states of the USA, Singapore, and Taiwan. Mr. Dinh estimates that a much larger number of jobs are supported indirectly by the sale of his product, including dealers, contractors, and manufacturer's representatives. Considering the number of manufacturers that have applied some of Mr. Dinh's technical breakthroughs to enhance their own products, Mr. Dinh believes that his invention has spawned an even larger industry.

According to Mr. Dinh, the ERIP grant came at a crucial time: "the [ERIP] grant was the critical boost needied to overcome the last significant barriers and clear the way to the commercial market." 
receipt of DOE funding, promising inventions sometimes have made enough progress that they no longer need ERIP's assistance. Occasionally, the Program encounters a participant who applied to the Program to gain access to the technical review process and then declines funds offered by ERIP. In other cases, grants are not awarded because the ERIP participant and the DOE/ERIP Invention Coordinator do not reach agreement concerning a statement of work.

The average grant size for the 475 inventions that received funding was $\$ 78,000$ (in current dollars). The range of variation in the size of awards has been relatively narrow. Forty percent of the awards have been between $\$ 70,000$ and $\$ 90,000$, and ninety percent fall between $\$ 40,000$ and $\$ 100,000$ (Fig. 8.1), the value of the grant being tailored to each invention.

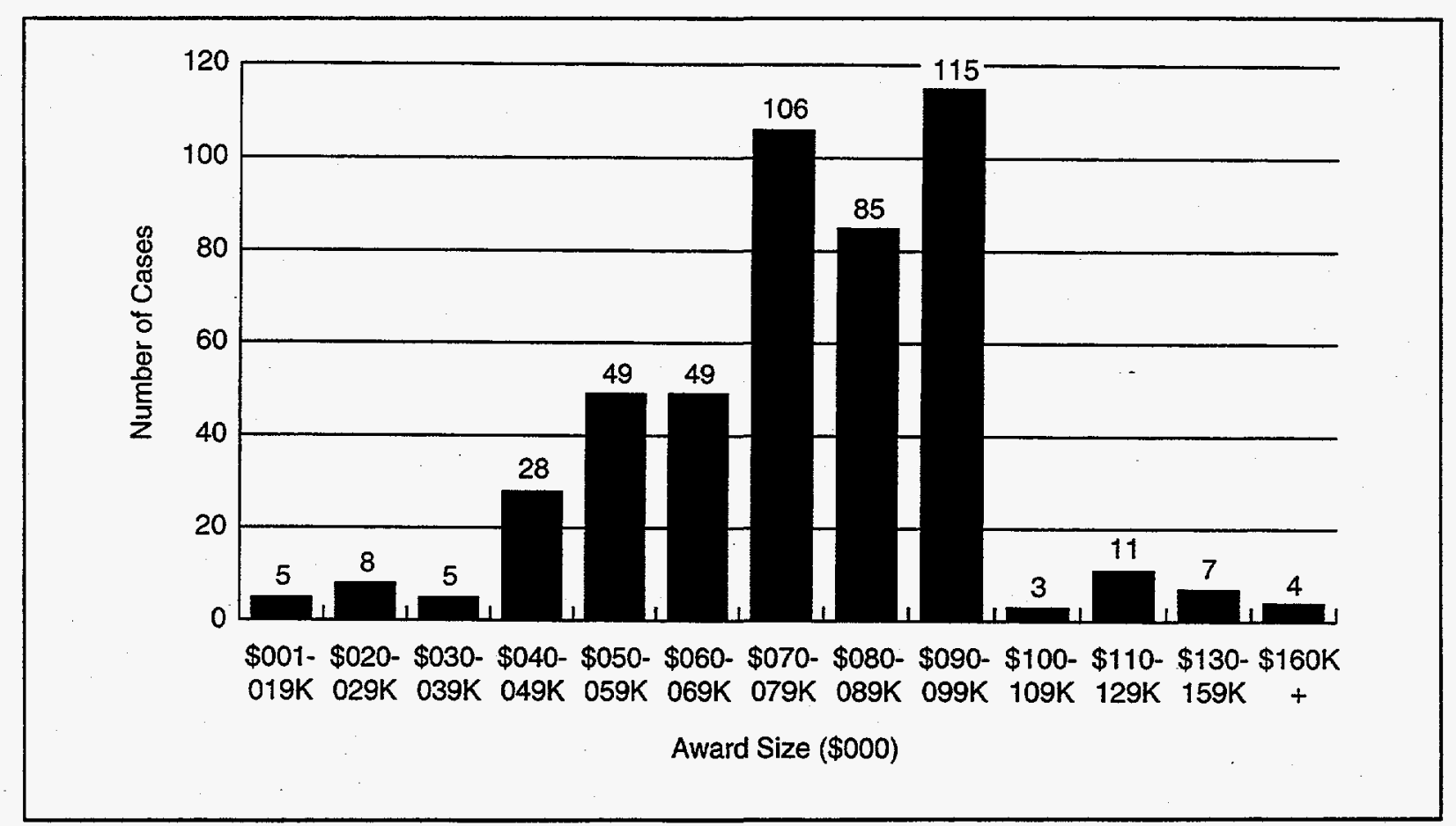

Fig. 8.1. Distribution of ERIP grant size for 475 projects.

As summarized in Table 8.2, there is little correlation between commercialization success and the size of the grants provided by ERIP. However, the receipt of an ERIP grant is associated with higher rates of market entry. 
Table 8.2. Project Performance Versus Receipt of ERIP Grant and Grant Size

\begin{tabular}{|c|c|c|c|c|c|c|}
\hline \multicolumn{7}{|c|}{ Size of ERIP Grant } \\
\hline $\begin{array}{l}\text { Performance } \\
\text { Measure: }\end{array}$ & $\begin{array}{r}\text { None } \\
(\mathrm{N}=134)\end{array}$ & $\begin{array}{l}\$ 4,888 \\
\$ 39,999 \\
(N=18)\end{array}$ & $\begin{array}{l}\$ 40,000 \\
\$ 59,999 \\
(N=77)\end{array}$ & $\begin{array}{l}\$ 60,000- \\
\$ 79,999 \\
(N=155)\end{array}$ & $\begin{array}{r}\$ 80,000 \\
\$ 99,999 \\
(N=200)\end{array}$ & $\begin{array}{r}\$ 100,000 \\
\$ 193,500 \\
(N=25)\end{array}$ \\
\hline $\begin{array}{l}\text { Percent with } \\
\text { Sales }\end{array}$ & 16 & 28 & 26 & 28 & 24 & 28 \\
\hline $\begin{array}{l}\text { Percent with } \\
\text { Sales }>\$ 500,000\end{array}$ & 11 & 11 & 13 & 13 & 11 & 20 \\
\hline
\end{tabular}

The fact that the 134 inventions that are not supported by an ERIP grant have a low rate of market entry underscores the overall value of receiving financial support from the Program. The lack of a statistical relationship between grant size and measures of performance suggests that the level of funding (at least within the range of funding available to DOE) is less important. Three factors would appear to contribute to this finding. First, the NIST review assures at least a minimum level of technical and market potential for each technology in the Program. This reduces any potential link between technical potential and the size of awards given. Second, the size of ERIP awards is small relative to the amount of total funding generally required by ERIP technologies to reach the marketplace. While the ERIP grant may help participants accomplish critical developmental tasks, participants must acquire the majority of their development and commercialization funding elsewhere. Third, there is a rather limited range in which ERIP grants fall. For example, three-quarters of the Program's grants awarded are within the range of $\$ 60,000-\$ 104,000$. Since projects can vary dramatically in terms of their overall funding needs, this means that grant size will not reflect the magnitude of funding required to bring technologies to successful commercialization.

\subsection{EVALUATION CONCLUSIONS}

This evaluation reveals that 1993-94 was a successful period for many ERIP technologies. By the end of 1994, at least 144 ERIP inventions (or 24\%) had entered the market, generating total cumulative sales of \$961 million (in 1994-\$). The success of ERIP inventors is also shown in their licensing revenues. It is estimated that in 1994 ERIP inventors earned royalties of $\$ 2.3$ million, and over the lifetime of the program, royalties total $\$ 28.2$ million. With $\$ 47.5$ million in grants awarded from 1975 through 1994 , and $\$ 124$ million in program appropriations over the same period, ERIP has generated a 20:1 return in terms of sales values to grants, and an 8:1 return in sales versus program appropriations. An analysis of sources of funding provides additional evidence of positive program impacts. While it is difficult to make exact comparisons 
between these percentages and other indicators of the success rates of technological innovations as a whole, the ERIP figures remain impressive.

The commercial progress of spinoff technologies is also documented. Altogether, 52 spinoff technologies have generated sales of $\$ 88$ million (in 1994-\$). Most of these involve alternative market applications of technologies that were first successfully introduced into their originally intended markets. Others are second-generation technologies. Figure 8.2 portrays the cumulative sales of ERIP's inventions and spinoff technologies over the lifetime of the program and compares these values to ERIP program appropriations and grant awards.

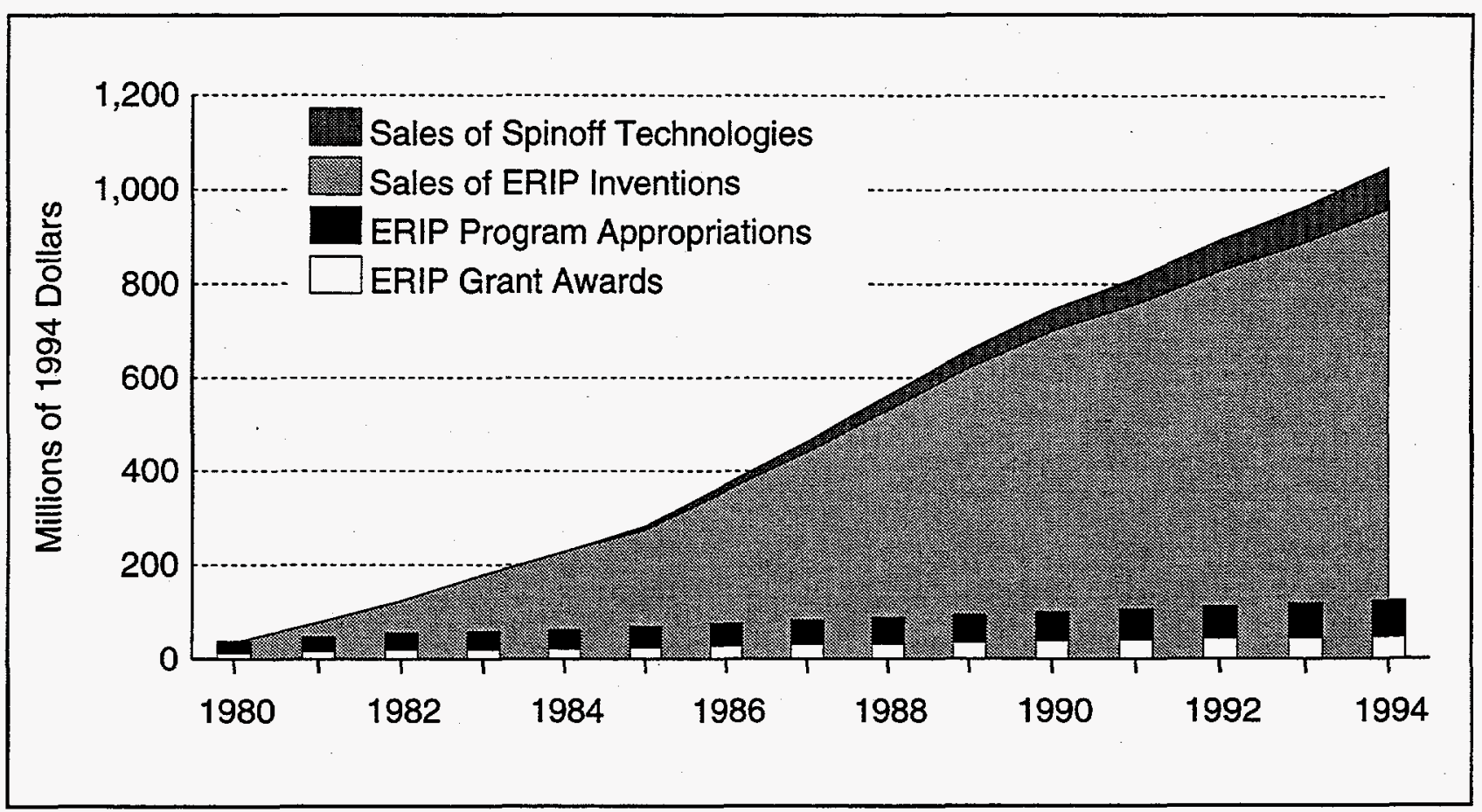

Fig. 8.2. Cumulative sales of ERIP inventions and spinoff technologies.

The employment and tax benefits associated with ERIP technologies are significant. It is estimated that at least 757 job-years were directly supported by ERIP technologies in 1994 . This employment is associated with a return of approximately $\$ 3.4$ million in individual income taxes to the U.S. Treasury.

Finally, this evaluation assessed the energy and environmental benefits associated with ERIP technologies. It documents that approximately \$334 million of energy expenditures were been saved in 1994 alone as a result of the commercial success of five ERIP projects. These energy savings have resulted in reduced emissions of over 2.1 million metric tons of carbon in 1994 alone. 



\section{REFERENCES}

Birley, S. 1987. "New Ventures and Employment Growth," Journal of Business Venturing 2(2): 155-165.

Booz-Allen \& Hamilton. 1982. Management for the 1980's. New York, New York: Booz-Allen \& Hamilton.

Brown, M. A., C. R. Curlee, and S. R. Elliott. 1995. "Evaluating Technology Innovation Programs: The Use of Comparison Groups to Identify Impacts," Research Policy, 24: 669-684.

Brown, M. A., C. R. Wilson, C. A. Franchuk, S. M. Cohn and D. Jones. 1994. The Economic, Energy, and Environmental Impacts of the Energy-Related Inventions Program. Oak Ridge, Tennessee: Oak Ridge National Laboratory, ORNL/CON-381.

Brown, M. A. and C. R. Wilson. 1993. "R\&D Spinoffs: Serendipity vs. A Managed Process," Journal of Technology Transfer, 18 (3-4): 5-15.

Brown, M. A., C. R. Wilson, and C. A. Franchuk. 1991. The Energy-Related Inventions Program: $A$ Decade of Commercial Progress. Oak Ridge, Tennessee: Oak Ridge National Laboratory, ORNL/CON-339, December.

Brown, M. A. and C. R. Wilson. 1990. The Energy Related-Inventions Program: Commercial Progress of Participants Through 1988. Oak Ridge, Tennessee: Oak Ridge National Laboratory, ORNL/CON-301, May.

Brown, M. A. and S. A. Snell. 1988. The Energy-Related Inventions Program: An Assessment of Recent Commercial Progress. Oak Ridge, Tennessee: Oak Ridge National Laboratory, ORNL/CON-252, October.

Brown, M. A., J. A. Morell, S. A. Snell, E. J. Soderstrom, and W Friggle. 1987. Evaluation of the EnergyRelated Inventions Program: An Empirical Analysis of 204 Inventions. Oak Ridge, Tennessee: Oak Ridge National Laboratory, ORNL/CON-225, March.

Campbell, D.T., and J. C. Stanley. 1971. Experimental and Quasi-Experimental Designs for Research, Chicago: Rand McNally and Co.

Chrisman, J. J., F. Hoy, and R. B. Robinson. 1987. "New Venture Development: The Costs and Benefits of Public Sector Assistance," Journal of Business Venturing, 2: 315-328.

Cooper, R. G. 1983. "Most New Products Do Succeed," Research Management, 26(6): 20-25, November-December.

Crawford, C. M. 1987. "New Product Failure Rates: A Reprise," Research Management, 30(4): 20-24, July-August.

Devlin, J. F., B. Leary, and J. Benson. 1992. "Compressor Control Retrofit Improves Pressure Control While Reducing Energy Costs," Turbomachines International Magazine, March/April 1992. 
Dombrowski, L. P., G. D. Pine, and R. C. Rinholm. 1991. "Benefits of GRI R\&D Products Placed in Commercial use Through Early 1991," Chicago, Illinois. Gas Research Institute, Gas Research Insights, May.

Energy Information Administration, U.S. Department of Energy. 1996. Monthly Energy Review. DOE/EIA0035. Washington, D.C.: Energy Information Administration, June.

Energy Information Administration, Office of Energy Markets and End Use, U.S. Department of Energy. 1995a. Annual Energy Review 1994. DOE/EIA-0384(94). Washington, DC: U.S. Government Printing Office.

Energy Information Administration, U.S. Department of Energy. 1995b. Emissions of Greenhouse Gases in the United States 1987-1994. DOE/EIA-0573(87-94). Washington, D.C.: Energy Information Administration, October.

Energy Information Administration, U.S. Department of Energy. 1991. Inventory of Power Plants in the United States 1990 DOE/EIA-0095. Washington, D.C.: Energy Information Administration, October.

The Futures Group. 1984. Characterization of Innovations Introduced on the U.S. Market in 1982, Washington, D.C.: U.S. Small Business Administration, Office of Advocacy, March, NTIS \#PB84 212067.

Horesh, R. and J. Y. Kamin. 1983. "How the Costs of Technological Innovation Are Distributed over Time," Research Management, 26(2): 21-24, March-April.

Kamin, J. Y., I. Bijaoui, and R. Horesh. 1982. "Some Determinants of Cost Distributions in the Process of Technological Innovation," Research Policy, 11(2): 83 -94.

Kirchhoff, B. A. and B. D. Phillips. 1988. "The Effect of Firm Formation and Growth on Job Creation in the United States," Journal of Business Venturing, 3: 261-272.

Meyer, M. H. and E. B. Roberts. 1986. "New Product Strategy in Small Technology-Based Firms: A Pilot Study", Management Science, 32(7): 806-821, July.

Meyer, M. H. and J. M. Utterback. 1993. "The Product Family and the Dynamics of Core Capability", Sloan Management Review, 34(3): 29-47.

Myers, S. and D. G. Marquis. 1969. Successful Industrial Innovations: A Study of Factors Underlying Innovations in Selected Firms, (NSF 69-17). Washington, D.C.: National Science Foundation.

Nexus Associates, Inc. 1996. Evaluation of the New York Manufacturing Extension Program Final Report, Gen \#95037. Belmont, MA: Nexus Associates, Inc.

Parr, Russell L. 1995. "Royalty Rates in General and on Average." The Journal of Technology Transfer. 20(2): 22.

RSPEC. 1993. A U.S. Department of Energy model: "Reduce Pool Energy Costs," Energy Efficiency and Renewable Energy Clearinghouse, Merrifield, VA. 
Roessner, J. David. 1989. "Evaluating Government Innovation Programs: Lessons from the U.S. Experience," Research Policy, 18: 343-359.

Rorke, M. L. and H. C. Livesay. 1986. A Longitudinal Examination of the Energy-Related Inventions Program. Rockville, Maryland: Mohawk Research Corporation.

Stead, H. 1976. "The Cost of Technological Innovation," Research Policy, 5: 2-9.

Tassey, G. 1995. Technology and Economic Growth: Implications for Federal Policy, National Institute of Standards and Technology, Department of Commerce, NIST Planning Report 95-3, Gaithersburg, MD, October.

U.S. Congress, Office of Technology Assessment. 1995. Innovation and Commercialization of Emerging Technology, OTA-BP-ITC-165. Washington, DC: U.S. Government Printing Office.

U.S. Department of Commerce, Bureau of the Census. 1995. Statistical Abstract of the United States, 1995, 115th Edition. Washington, DC, p. 347: U.S. Government Printing Office.

U.S. Department of Energy, Office of Science Policy. 1995a. Corporate R\&D Transition: Changing Patterns of Private Sector Investment in Research and Development. Washington, DC: U.S. Government Printing Office.

U.S. Department of Energy, Office of Energy Efficiency \& Renewable Energy. 1995b. Energy for Today and Tomorrow, Investments for a Strong America. Washington, DC: U.S. Government Printing Office.

U.S. Department of Transportation, Bureau of Transportation Statistics. 1994. Transportation Statistics Annual Report, 1994. Washington, DC: Bureau of Transportation Statistics.

Weigand, R.E. 1986. "Marketing Through Foreign Subsidiaries and Joint Venture Arrangements," Handbook of Modern Marketing, Victor P. Buell, eds. Cambridge, Massachusetts: Massachusetts Institute of Technology. 

APPENDIX A

QUESTIONNAIRE 

Project Number:

Primary Contact:

DOE Invention

Coordinator:

\section{TECHNOLOGY DESCRIPTION}

The following title and description are based on the status of the technology when ERIP support was initially requested. Please revise them if they are no longer correct.

\section{TTT:}

\section{ORIGINAI DESCRIPTION}


Project Number:

\section{CONTACT INFORMATION}

\begin{tabular}{|l|l|l|}
\hline $7:$ : & \\
\hline Name & & \\
\hline Company & & \\
\hline Address & & \\
\hline City & & \\
\hline State \& Zip Code & & \\
\hline Home Phone & & \\
\hline Office Phone & & \\
\hline Fax Number & & \\
\hline
\end{tabular}

\section{CONTACT'S EDUCATIONAL BACKGROUND}

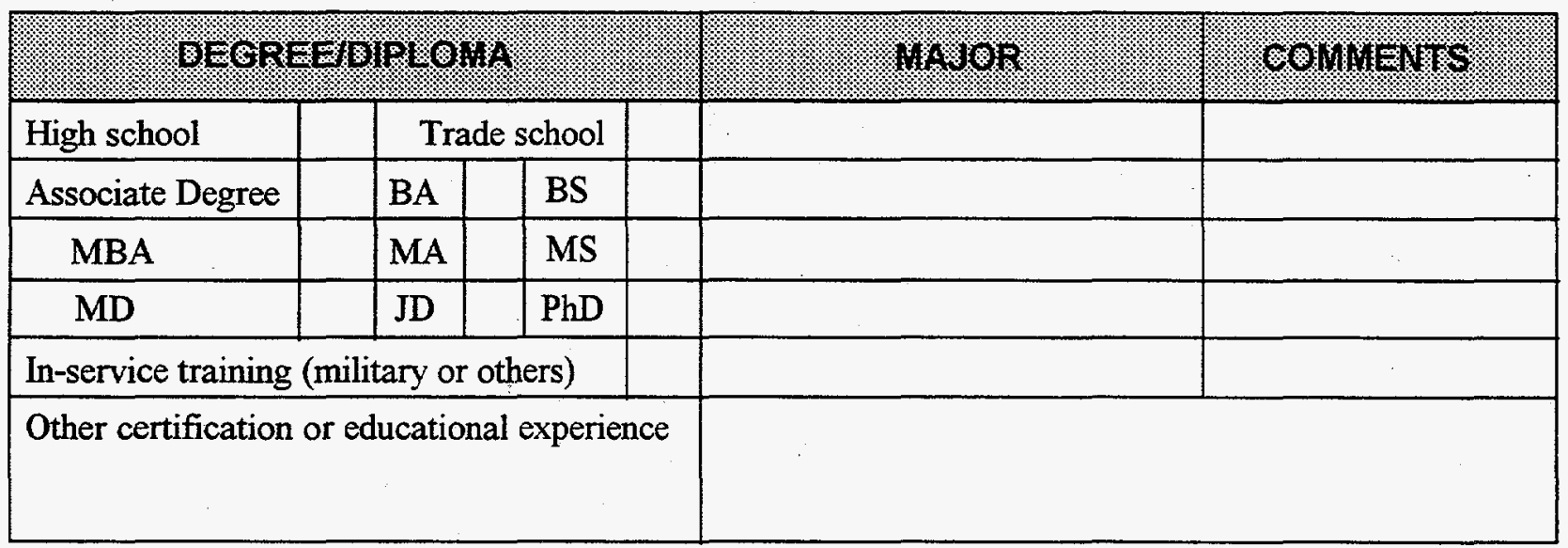

\section{CONTACT'S ASSOCIATION WITH THIS PROJECT}

We would like to know how you are related to this ERIP technology. Please check one or more boxes below. If your circumstance does not fit any of the listed categories, please describe it in the space provided.

Inventor

Applicant

Licensee

Owner of technology

Designated contact
Developer of technology

Other (Describe below)

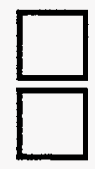


Project Number:

\section{CONTACT'S EMPLOYMENT HISTORY}

\begin{tabular}{|c|c|c|c|c|}
\hline \multicolumn{5}{|c|}{ 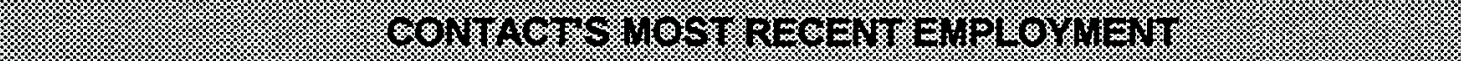 } \\
\hline \multicolumn{5}{|l|}{ Company } \\
\hline \multicolumn{5}{|c|}{ Your Position or Job Role } \\
\hline \multirow{2}{*}{$\begin{array}{l}\text { Number of employees } \\
\text { in company }\end{array}$} & (.). & $16.4 \%$ & $(8.6 \%$ & 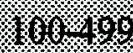 \\
\hline & $304699 \%$ & 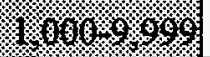 & $10,600 \%$ & \\
\hline Years of employment & Hits: & & 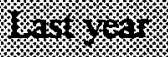 & \\
\hline
\end{tabular}

\begin{tabular}{|c|c|c|c|c|}
\hline \multicolumn{5}{|c|}{ 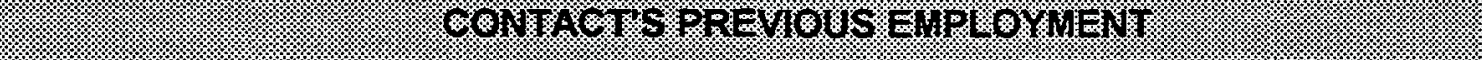 } \\
\hline \multicolumn{5}{|l|}{ Company } \\
\hline \multicolumn{5}{|c|}{ Your Position or Job Role } \\
\hline \multirow{2}{*}{$\begin{array}{l}\text { Number of employees } \\
\text { in company }\end{array}$} & (1: & 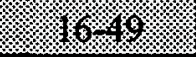 & $280.6 \%$ & $100 \% 1 \%$ \\
\hline & 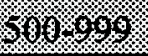 & 1860.9099 & 16.608. & \\
\hline Years of employment & (1) & & ato & \\
\hline
\end{tabular}

\section{INVENTOR'S BACKGROUND AT TIME OF CONCEPTUALIZATION}

We are interested in the inventor's background at the time when the ERIP invention was conceptualized. This information will help us to better understand the commercialization process of the invention.

\begin{tabular}{|c|c|c|c|c|c|}
\hline Inventor's Name & & & $\begin{array}{l}\text { Inventor } \\
\text { position }\end{array}$ & & \\
\hline \multicolumn{6}{|c|}{$\begin{array}{l}\text { Company in which inventor } \\
\text { worked }\end{array}$} \\
\hline \multirow{2}{*}{$\begin{array}{l}\text { Number of employees } \\
\text { in company }\end{array}$} & 36 & (6.8.48: & \multicolumn{2}{|c|}{ (6.6. } & 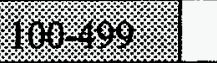 \\
\hline & 910.909 & 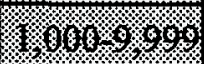 & \multicolumn{2}{|c|}{$10.00 \%$} & \\
\hline \multicolumn{3}{|c|}{ Did the inventor see a potential market for the invention? } & (1) & 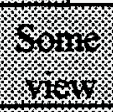 & Hoingor \\
\hline \multicolumn{3}{|c|}{ Did the inventor have any technical inventions before? } & (1) & $\sqrt{12}$ & Hoven \\
\hline \multicolumn{3}{|c|}{ Were any of these inventions commercially successful? } & 18. & 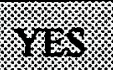 & Hon \\
\hline
\end{tabular}


Project Number:

\section{DEVELOPMENT AND ACTIVITY STATUS OF THIS TECHNOLOGY}

This information helps us track the chronological development and activity status of the ERIP technology. Please use the following development and activity status categories to update the table below.

\section{DEVELOPMENT CATEGORIES}

$0=$ Technology originally conceptualized

$1=$ Concept definition and development

$2=$ Working model

$3=$ Prototype development/testing/engineering design

$4=$ Pre-production prototype testing

$5=$ Production prototype

$6=$ Limited production and marketing

$7=$ Full production and marketing

\section{ACTIVITY CATEGORIES}

$0=$ Active development began

$1=$ Actively being pursued

$2=$ Low level of effort

$3=$ Suspended temporarily

4 = Suspended indefinitely

$5=$ Failed

$6=$ Chapter 11/Reorganization

$7=$ Chapter $7 /$ Bankrupt

\section{HISTORY OF DEVELOPMENT AND ACTIVITY STATUS}

Please complete the table if the status information is missing for some previous years.

\begin{tabular}{|c|c|c|c|}
\hline $4 \%$ & 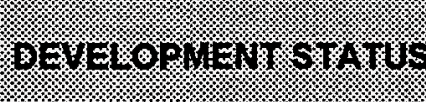 & 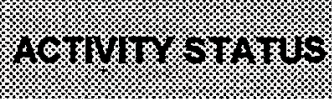 & 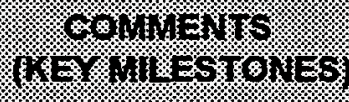 \\
\hline 1980 & & & \\
\hline 1981 & & & \\
\hline 1982 & & & \\
\hline 1983 & & & \\
\hline 1984 & & & \\
\hline 1985 & & & \\
\hline 1986 & & & \\
\hline 1987 & & & \\
\hline 1988 & & & \\
\hline 1989 & & & \\
\hline 1990 & & & \\
\hline 1991 & & & \\
\hline 1992 & & & \\
\hline 1993 & & & \\
\hline 1994 & & & \\
\hline
\end{tabular}


Project Number:

\section{ENERGY, ENVIRONMENTAL, AND OTHER BENEFITS}

We are interested in knowing about the features of your ERIP technology that you believe represent energy and/or environmental benefits to users or to the public. Please check all the boxes below that are applicable to your technology and provide a brief description for all those you check.

\section{ENERGY BENEFITS}

Renewable energy production (solar, wind, etc.)

Non-renewable energy production

Energy efficiency improvement

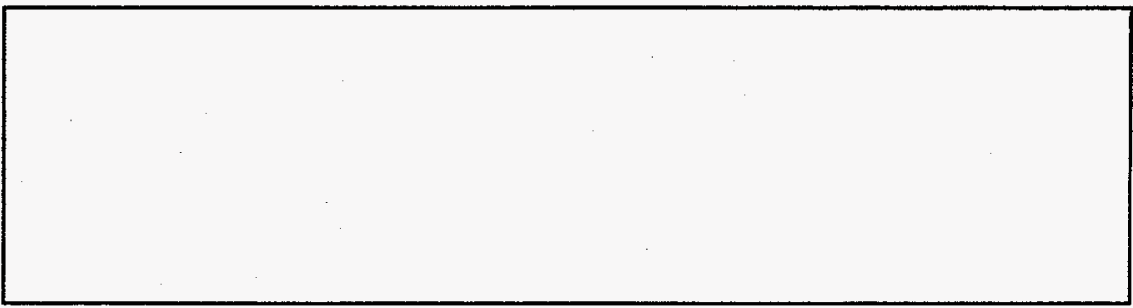

\section{ENVIRONMENTAL BENEFITS}

\section{OTHER BENEFITS}

by using less material by recycling

to air

to water

to soil

Waste reduction

Other

quality or performance improvements reduction of manufacturing costs 
Project Number:

\section{SALES DATA}

Information on sales of your ERIP technology is essential to our assessment of the assistance provided by ERIP. Gross revenue helps us understand the relationship between technical development and the growth of small business. If your firm is a division of a larger firm that transfers a significant amount of development funds to you, please give us an estimate of the revenues of the parent company. If your company is independent but has revenues from other products and services, please note the revenues of your own company in the boxes below.

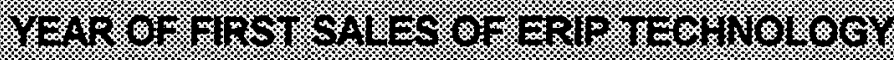

\begin{tabular}{|c|c|c|c|c|}
\hline \multirow[b]{2}{*}{ YEAR } & \multicolumn{3}{|c|}{ SALES OF ERIP TECHNOLOGY } & \multirow{2}{*}{$\begin{array}{l}\text { GROSS SALES OF } \\
\text { YOUR COMPANY } \\
\text { (Across all product } \\
\text { lines, including ERIP } \\
\text { sales) } \\
(\$)\end{array}$} \\
\hline & 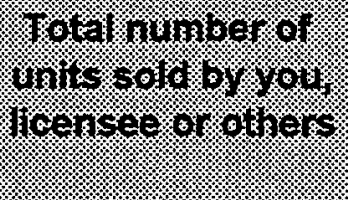 & 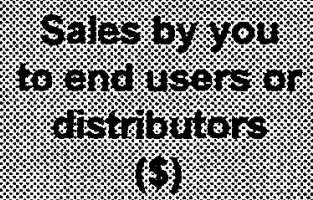 & Soligs oy ricenser & \\
\hline \multicolumn{5}{|l|}{1980} \\
\hline \multicolumn{5}{|l|}{1981} \\
\hline \multicolumn{5}{|l|}{1982} \\
\hline \multicolumn{5}{|l|}{1983} \\
\hline \multicolumn{5}{|l|}{1984} \\
\hline \multicolumn{5}{|l|}{1985} \\
\hline 1986 & & & & - \\
\hline \multicolumn{5}{|l|}{1987} \\
\hline \multicolumn{5}{|l|}{1988} \\
\hline \multicolumn{5}{|l|}{1989} \\
\hline \multicolumn{5}{|l|}{1990} \\
\hline \multicolumn{5}{|l|}{1991} \\
\hline \multicolumn{5}{|l|}{1992} \\
\hline \multicolumn{5}{|l|}{1993} \\
\hline 1994 & & & & \\
\hline
\end{tabular}

\section{FOREIGN SALES OF ERIP TECHNOLOGY}

The development of foreign markets for U.S. technology is of great interest to the Energy Related Invention Program. Please provide your foreign sales information in the table below.

Has your ERIP technology been sold outside of the U.S. ?

If yes, please estimate your total foreign sales to date. (These sales should also be included in the above table.)

\begin{tabular}{|l|l|}
\hline & $\square$ YES \\
\hline
\end{tabular}


Project Number:

\section{LICENSING REVENUE}

Information about licensing revenue helps us to examine the relative success of different approaches to commercialization. If your ERIP technology has not been licensed and its patent has not been sold, skip to the next page.

Royalties: These are total annual royalties received or paid out based on actual sales of your ERIP technology.

Royalty rate: This is the average royalty percentage per dollar sale. If multiple royalty rates are in operation, please give us a weighted rate.

Other licensing This includes up-front payments, bonuses, or other licensing revenues not tied to payments: actual sales.

LICENSE AND PURCHASE AGREEMENTS

\begin{tabular}{|c|c|c|c|}
\hline YEAR & 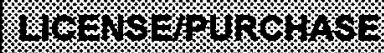 & 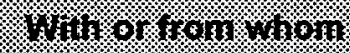 & 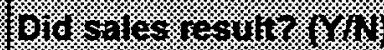 \\
\hline & & & \\
\hline & & & \\
\hline
\end{tabular}

LICENSING REVENUES

\begin{tabular}{|c|c|c|c|}
\hline YEAR & 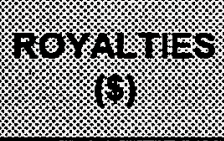 & 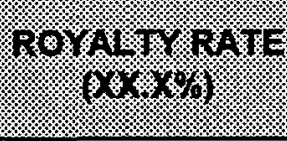 & OMF ER \\
\hline \multicolumn{4}{|l|}{1980} \\
\hline \multicolumn{4}{|l|}{1981} \\
\hline \multicolumn{4}{|l|}{1982} \\
\hline \multicolumn{4}{|l|}{1983} \\
\hline \multicolumn{4}{|l|}{1984} \\
\hline \multicolumn{4}{|l|}{1985} \\
\hline \multicolumn{4}{|l|}{1986} \\
\hline \multicolumn{4}{|l|}{1987} \\
\hline \multicolumn{4}{|l|}{1988} \\
\hline \multicolumn{4}{|l|}{1989} \\
\hline \multicolumn{4}{|l|}{1990} \\
\hline \multicolumn{4}{|l|}{1991} \\
\hline \multicolumn{4}{|l|}{1992} \\
\hline \multicolumn{4}{|l|}{1993} \\
\hline 1994 & & & \\
\hline
\end{tabular}


Project Number:

\section{EMPLOYMENT}

Information about employment generated by your ERIP technology helps us examine the degree to which the ERIP program has been successful in generating jobs.

Direct ERIP Please list only the number of employees of your company that can be directly Employment: attributed to the technology sponsored by the ERIP program.

Indirect ERIP If other organizations employ individuals whose jobs are related to the production, Employment: marketing or distribution of your ERIP technology, please estimate these. Indirect ERIP employees could include suppliers, subcontractors, retailers, licensees, or others whom you do not directly employ.

Please use Full-Time Equivalents (FTE) (2 Half Time = 1 FTE).

\section{EMPLOYMENT ASSOCIATED WITH THE ERIP TECHNOLOGY}

\begin{tabular}{|c|c|c|c|}
\hline YEAR & 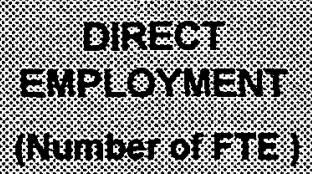 & 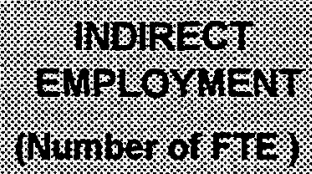 & 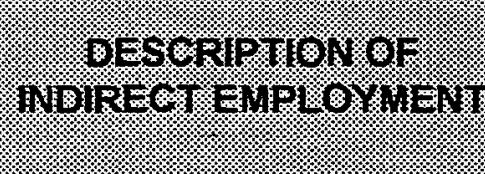 \\
\hline \multicolumn{4}{|l|}{1980} \\
\hline \multicolumn{4}{|l|}{1981} \\
\hline \multicolumn{4}{|l|}{1982} \\
\hline \multicolumn{4}{|l|}{1983} \\
\hline \multicolumn{4}{|l|}{1984} \\
\hline \multicolumn{4}{|l|}{1985} \\
\hline \multicolumn{4}{|l|}{1986} \\
\hline \multicolumn{4}{|l|}{1987} \\
\hline \multicolumn{4}{|l|}{1988} \\
\hline \multicolumn{4}{|l|}{1989} \\
\hline \multicolumn{4}{|l|}{1990} \\
\hline \multicolumn{4}{|l|}{1991} \\
\hline \multicolumn{4}{|l|}{1992} \\
\hline \multicolumn{4}{|l|}{1993} \\
\hline 1994 & & & \\
\hline
\end{tabular}




\section{DEFINITIONS OF CATEGORIES OF FUNDING}

Please use the following funding types when describing your sources of funding on the next page.

\begin{tabular}{|c|c|}
\hline CATEGORY & EOUITY INYESTMENTS \\
\hline Sweat Equity & Estimated value of uncompensated labor. \\
\hline Personal/Mgt Team & Personal funds and those from the development team. \\
\hline $\begin{array}{l}\text { Informal Equity } \\
\text { Investment by Friends } \\
\text { and Family }\end{array}$ & $\begin{array}{l}\text { Equity investment from friends and relatives who are not associated with } \\
\text { formal investment organizations and who are not professional private } \\
\text { investors. May involve distribution of private stock. }\end{array}$ \\
\hline Venture Capital & $\begin{array}{l}\text { Equity investments from formal venture capital organizations. This includes } \\
\text { funding from SBDICs and venture partnerships developed to invest in the } \\
\text { technology, as well as professional or sophisticated private investors. }\end{array}$ \\
\hline Public Stock & Public stock offerings. \\
\hline $\begin{array}{l}\text { Federal R\&D Contracts } \\
\text { \& Grants other than the } \\
\text { ERIP Grant }\end{array}$ & $\begin{array}{l}\text { Federal R\&D contracts and grants, such as SBIR, DOE, DOD, etc. This } \\
\text { does not include the grant you got from the Energy-Related Inventions } \\
\text { Program. }\end{array}$ \\
\hline $\begin{array}{l}\text { State \& Local Grants \& } \\
\text { R\&D Contracts }\end{array}$ & Grants and $R \& D$ contracts from State and local agencies. \\
\hline $\begin{array}{l}\text { Retained Earnings from } \\
\text { Sales }\end{array}$ & $\begin{array}{l}\text { Reinvested profits from sales. This is that portion of profits from sales that } \\
\text { is reinvested in the company. }\end{array}$ \\
\hline Other Equity & $\begin{array}{l}\text { Equity funding from other sources, e.g., preferred stock subordinated } \\
\text { debentures. }\end{array}$ \\
\hline OATEGORY & DEBT INVESTMENTS \\
\hline $\begin{array}{l}\text { Supplier and Customer } \\
\text { Credit }\end{array}$ & $\begin{array}{l}\text { Trade credit from suppliers and Work-in-Progress payments from } \\
\text { customers. }\end{array}$ \\
\hline Banks & $\begin{array}{l}\text { Commercial bank loans. This would include long-term loans to cover } \\
\text { development costs, real estate purchases, etc., as well as short-term loans to } \\
\text { cover inventory, etc. }\end{array}$ \\
\hline $\begin{array}{l}\text { Federal, State, \& Local } \\
\text { Guaranteed Loans }\end{array}$ & $\begin{array}{l}\text { Loans guaranteed by Federal, State, and local agencies, including loans } \\
\text { guaranteed by the Small Business Administration. }\end{array}$ \\
\hline $\begin{array}{l}\text { Informal Debt } \\
\text { Investment }\end{array}$ & $\begin{array}{l}\text { Debt investment from friends and relatives who are not associated with } \\
\text { formal investment organizations. }\end{array}$ \\
\hline Other Debt & Debt funding from any other source, e.g., operating or capitalized leases. \\
\hline
\end{tabular}


Project Number:

\section{SOURCES OF FUNDING FOR ERIP TECHNOLOGY}

\begin{tabular}{|c|c|c|c|}
\hline \multicolumn{2}{|c|}{ 4. } & 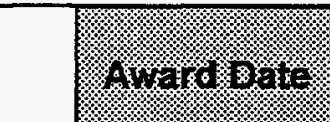 & ER?: $\mathrm{G}$ : \\
\hline 8.80 & 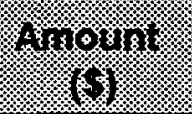 & \multicolumn{2}{|c|}{ 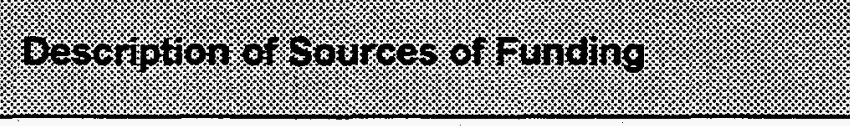 } \\
\hline & & & \\
\hline & & & \\
\hline & & & \\
\hline & & & \\
\hline & & & \\
\hline
\end{tabular}

FOREIGN SOURCES OF FUNDING

Have any of these funds come from foreign sources?

If yes, please report the total amount of foreign investment to date.

YES

NO

$\$$ 
Project Number:

\section{SPINOFF TECHNOLOGIES}

There are several ways in which spinoff technologies can arise.

1. Development of an initial technology results in new product characteristics that adapt the product for new markets.

2. Efforts to solve a problem with an initial technology fail, so a different approach is used to resolve the same problem and a new technology results.

3. A new application is found for a component of an initial product.

If any of the criteria above apply to your ERIP technology, please describe below your successful spinoff technologies that you have developed as a result of your ERIP project.

If you have more than 2 spinoff technologies, please report on additional page(s) in the same format as below and attach the page(s) at the end of the questionnaire.

* Please note that we are requesting sales in "thousands of dollars".

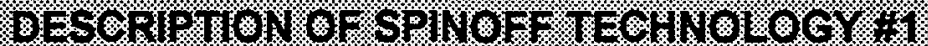

\begin{tabular}{|c|c|c|c|c|c|c|c|c|c|c|}
\hline & 1986 & 1086 & $188 \%$ & 4988 & 1989 & 1980 & 1998 & 1992 & 8983 & 490 \\
\hline Sales $(\$, 000)^{*}$ & & & & & & & & & & \\
\hline $\begin{array}{l}\text { Licensing } \\
\text { Royalties }(\$, 000)^{*}\end{array}$ & & & & & & & & & & \\
\hline
\end{tabular}

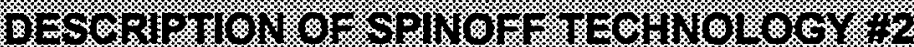

\begin{tabular}{|c|c|c|c|c|c|c|c|c|c|c|}
\hline & 8983 & 1986 & 19687 & 4888 & 18980 & 1990 & $60 \%$ & 1099 & 8993 & 1994 \\
\hline Sales $(\$, 000)^{*}$ & & & & & & & & & & \\
\hline $\begin{array}{l}\text { Licensing } \\
\text { Royalties }(\$, 000)^{*}\end{array}$ & & & & & & & & & & \\
\hline
\end{tabular}


Project Number:

\section{CONTACT'S EXPERIENCE WITH STARTUP COMPANIES}

How many startup companies have you been personally involved with?

\begin{tabular}{|c|c|}
\hline 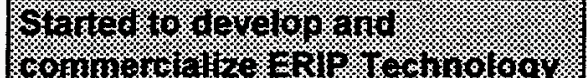 & 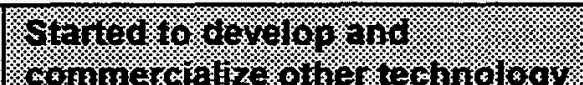 \\
\hline
\end{tabular}

\begin{tabular}{|l|l|l|l|}
\hline Location & & \\
\hline Year company started & & \\
\hline Your job role & & \\
\hline $\begin{array}{l}\text { Was there a connection } \\
\text { between this startup } \\
\text { company and the ERIP } \\
\text { technology? }\end{array}$ & $\square$ No $\square$ Yes (explain below) & $\square$ No $\square$ Yes (explain below) \\
\hline
\end{tabular}

\section{PATENTING ACTIVITY}

We are interested in understanding the degree to which your ERIP technology has patent protection, and the degree to which your patented technologies have been developed into commercial products.

In most cases, our contact is the inventor, and patenting activity should go in the first column below. Occasionally a technology is further developed by individuals other than the inventor. If you are not the inventor, but you (or your company) have received patents, please record this in the second (or third) column below.

\begin{tabular}{|c|c|c|c|c|c|c|c|}
\hline \multirow{2}{*}{\multicolumn{2}{|c|}{\begin{tabular}{|l} 
PATENT ISSUED TO \\
TYPE OF PATENT
\end{tabular}}} & \multicolumn{2}{|c|}{ The inventor } & \multicolumn{2}{|c|}{$\begin{array}{l}\text { The contact, if } \\
\text { different from } \\
\text { inventor }\end{array}$} & \multicolumn{2}{|c|}{$\begin{array}{l}\text { Company } \\
\text { developing the } \\
\text { ERIP technology }\end{array}$} \\
\hline & & \multirow[t]{2}{*}{ 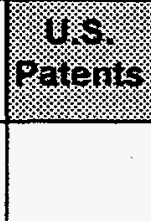 } & \multirow[t]{2}{*}{ 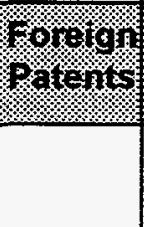 } & \multirow[t]{2}{*}{ 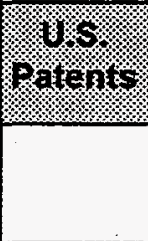 } & \multirow[t]{2}{*}{ 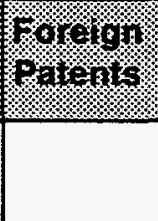 } & \multirow[t]{2}{*}{ 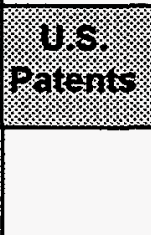 } & \multirow[t]{2}{*}{ 3.8. } \\
\hline $\begin{array}{l}\text { ERIP } \\
\text { Technology }\end{array}$ & $\#$ of patents issued & & & & & & \\
\hline \multirow{2}{*}{$\begin{array}{l}\text { Non-ERIP } \\
\text { Technology }\end{array}$} & \# of patents issued & & & & & & \\
\hline & $\begin{array}{l}\text { \# of patents associated with } \\
\text { a commercialized technology }\end{array}$ & & & & & & \\
\hline
\end{tabular}


Project Number:

\section{DIFFICULTIES OF COMMERCIALIZATION ACTIVITIES}

Please rate the difficulty level for each of the following activities in commercializing your ERIP technology.

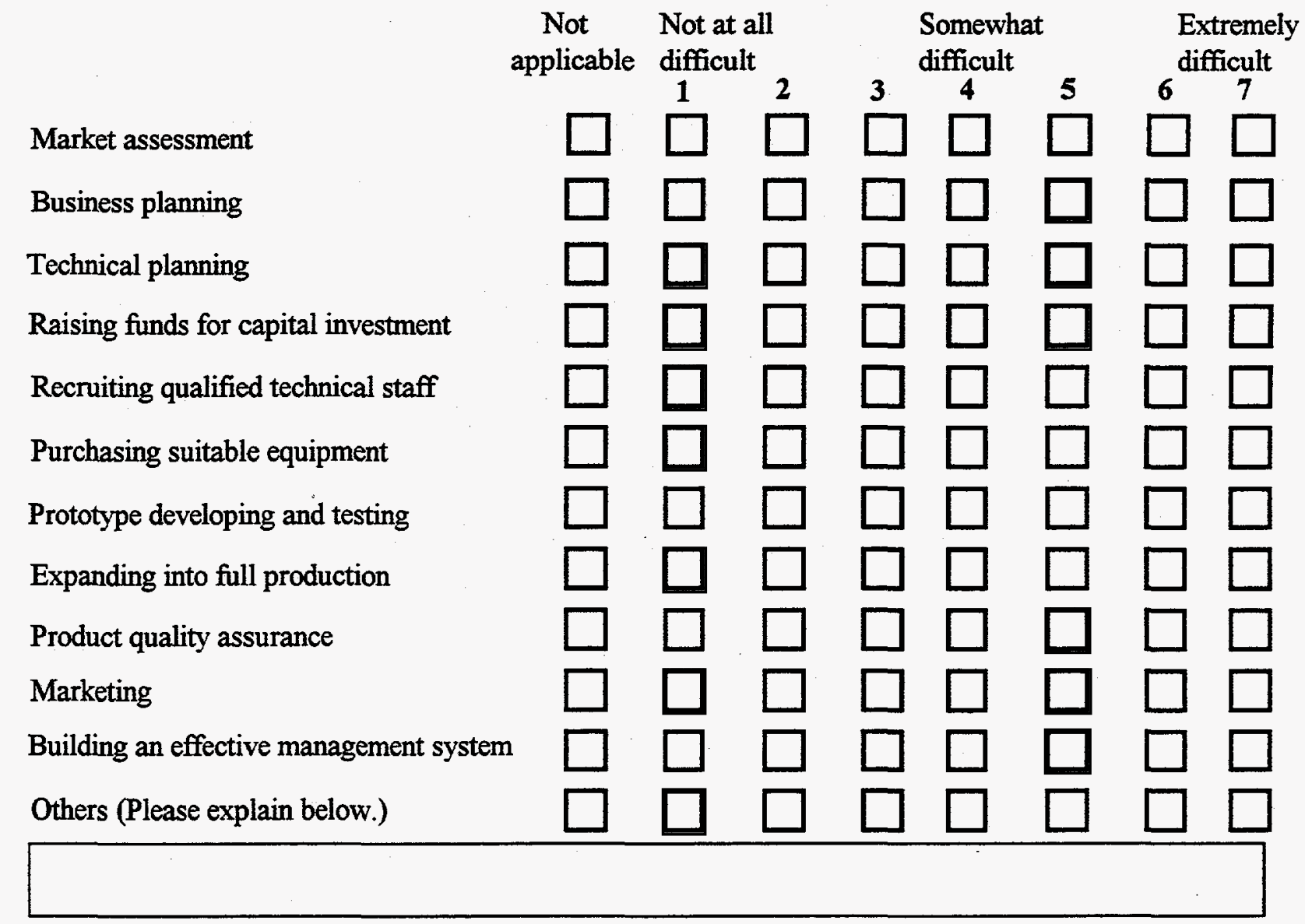

\section{ERIP ASSISTANCE}

ERIP seeks to accelerate the commercialization of energy-related inventions by offering several types of assistance. Please rate the helpfulness level for each type of assistance in commercializing your ERIP technology.

Technical evaluation by NIST

Grant (Skip if no DOE grant has been received)

Not at all

helpful

Commercialization Planning Workshop

Assistance with networking and other benefits provided by DOE Invention Coordinators

Assistance with raising funds due to the credibility associated with participation in ERIP Assistance with sales or licensing due to the credibility associated with participation in ERIP

$$
1
$$
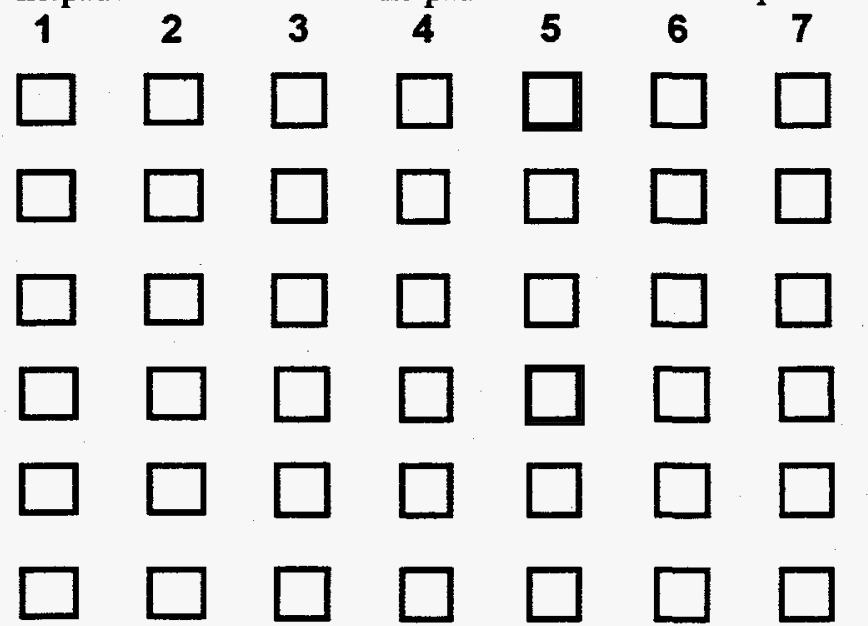
What other types of assistance from the ERIP program would have helped you to commercialize your ERIP technology?

In your own words, how did the ERIP program help you or your company?

\section{ADDITIONAL COMMENTS}

Would you like us to send you a copy of our final report on 
APPENDIX B

MARKET ENTRIES AND EXITS 

Market Entries and Exits

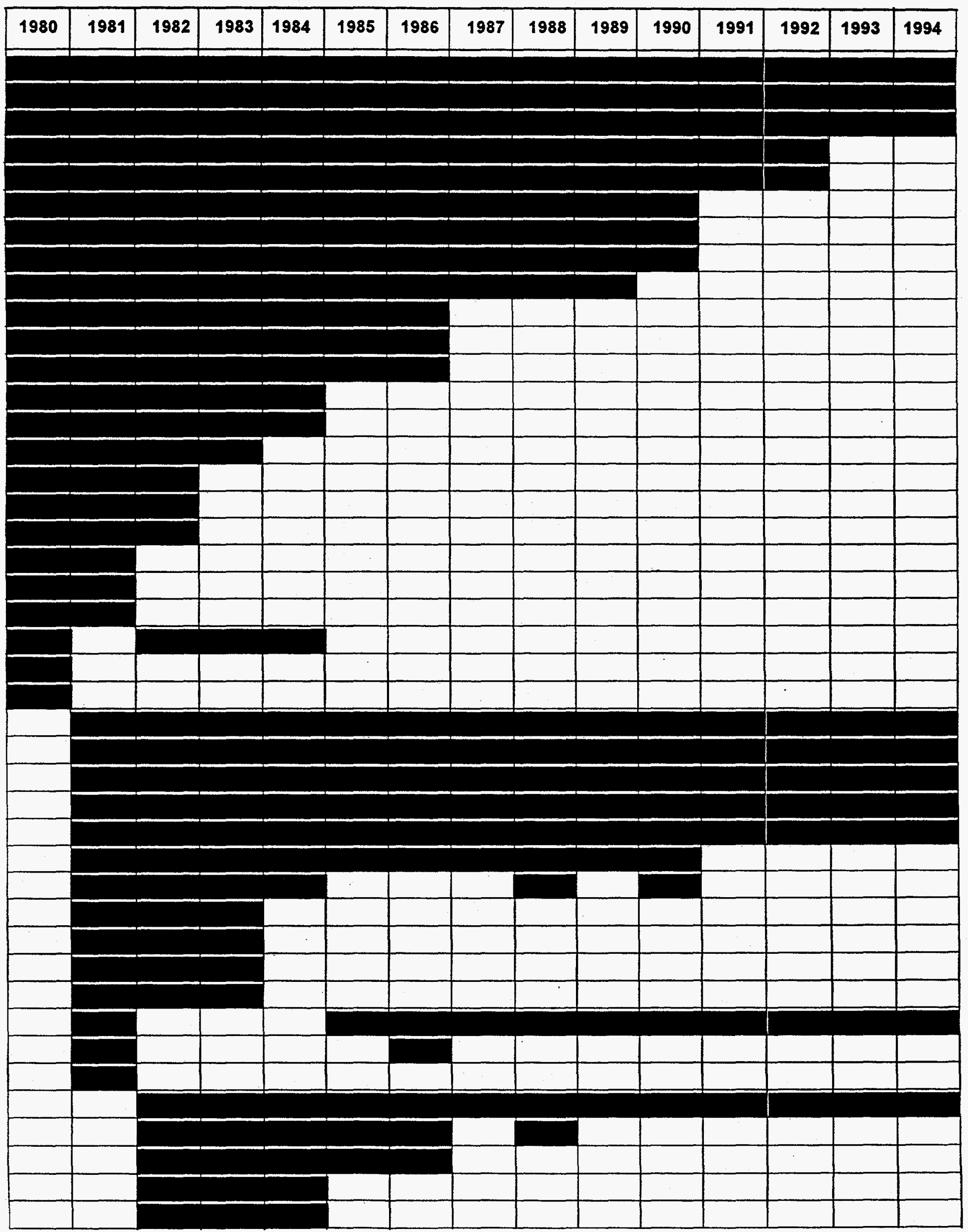


Market Entries and Exits

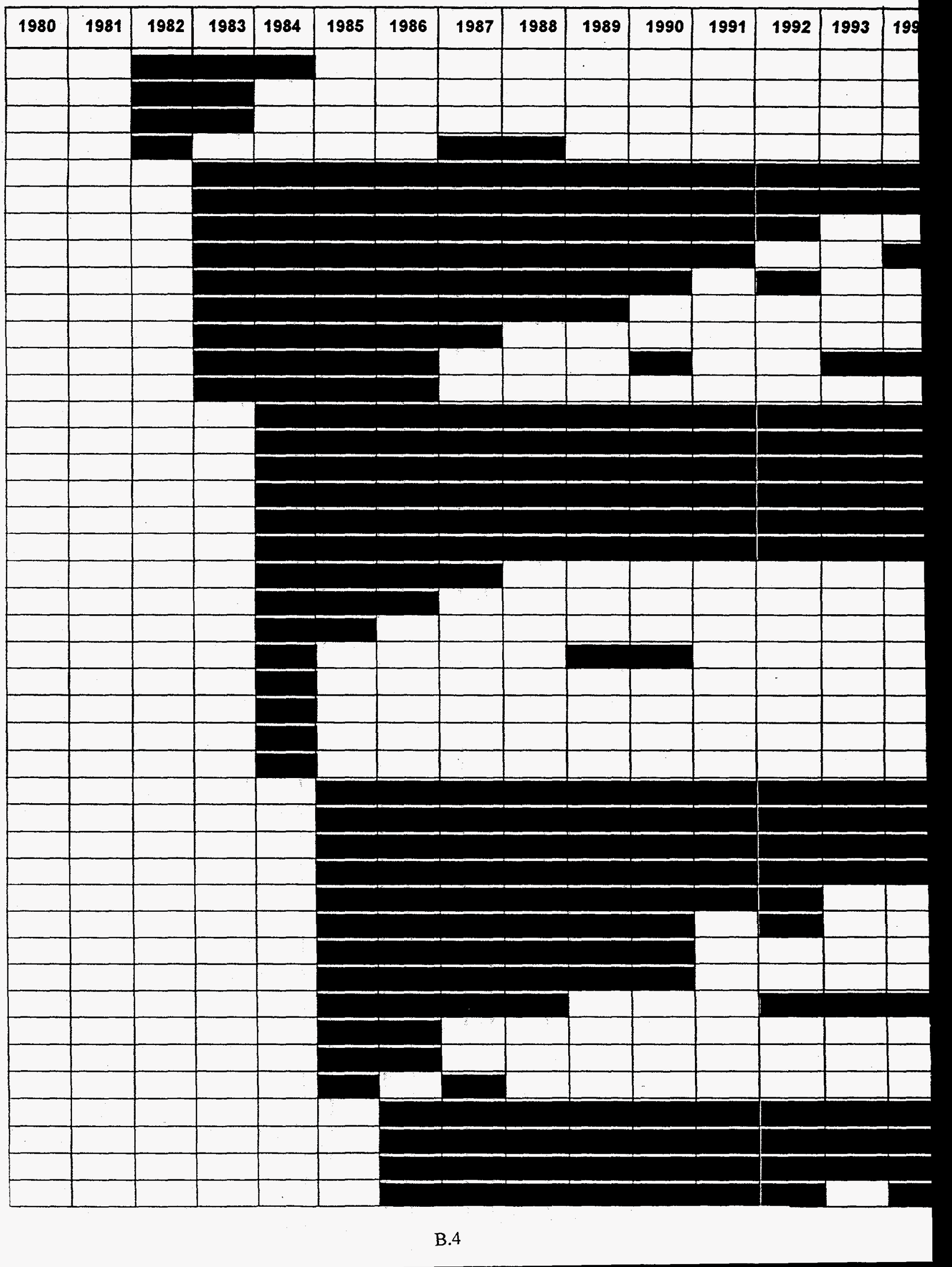


Market Entries and Exits

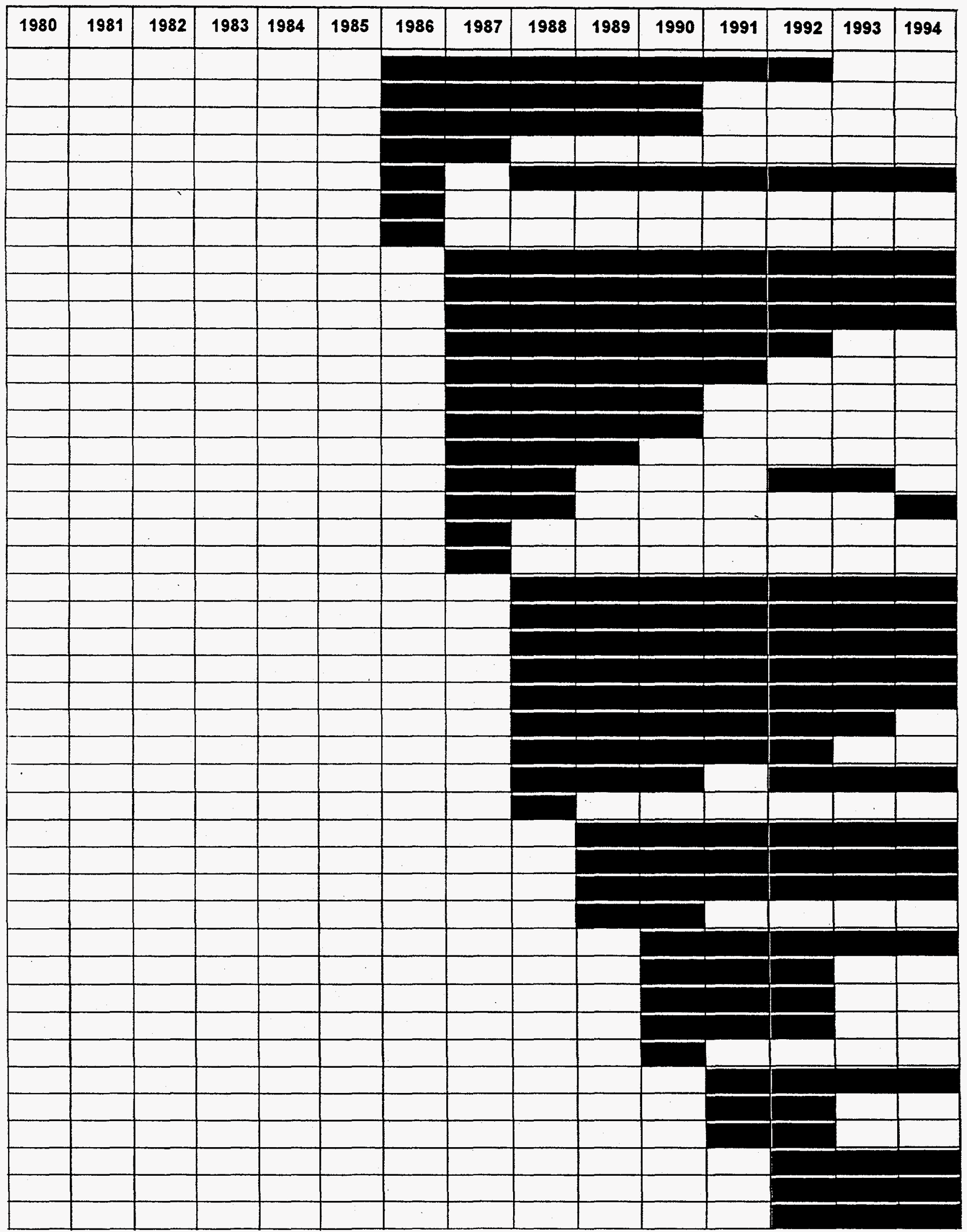


Market Entries and Exits

\begin{tabular}{|l|l|l|l|l|l|l|l|l|l|l|l|l|l|l|}
\hline 1980 & 1981 & 1982 & 1983 & 1984 & 1985 & 1986 & 1987 & 1988 & 1989 & 1990 & 1991 & 1992 & 1993 & 199 \\
\hline & & & & & & & & & & & & & \\
\hline & & & & & & & & & & & & & \\
\hline & & & & & & & & & & & & & & \\
\hline & & & & & & & & & & & & & & \\
\hline & & & & & & & & & & & & & & \\
\hline & & & & & & & & & & & & & & \\
\hline & & & & & & & & & & & & & & \\
\hline & & & & & & & & & & & & & & \\
\hline & & & & & & & & & & & & & & \\
\hline & & & & & & & & & & & & & & \\
\hline & & & & & & & & & & & & & & \\
\hline & & & & & & & & & & & & & & \\
\hline & & & & & & & & & & & & & & \\
\hline & & & & & & & & & & & & & & \\
\hline
\end{tabular}


APPENDIX C

SUPPORTING DATA 

Table C.1. Total Annual Royalties from Sales of ERIP Technologies (in thousands of dollars)

\begin{tabular}{|c|c|c|c|}
\hline Year & $\begin{array}{l}\text { Number of Inventions } \\
\text { with Royalties }\end{array}$ & $\begin{array}{l}\text { Royalties in Current } \\
\text { Dollars }\end{array}$ & $\begin{array}{l}\text { Royalties in } 1994 \\
\text { Dollars }\end{array}$ \\
\hline 1980 & 7 & 841 & 1,512 \\
\hline 1981 & 10 & 924 & 1,507 \\
\hline 1982 & 11 & 1,077 & 1,655 \\
\hline 1983 & 15 & 1,309 & 1,948 \\
\hline 1984 & 15 & 845 & 1,206 \\
\hline 1985 & 15 & 735 & 1,012 \\
\hline 1986 & 17 & 1,392 & 1,882 \\
\hline 1987. & 20 & 1,345 & 1,756 \\
\hline 1988 & 23 & 2,002 & 2,508 \\
\hline 1989 & 24 & 2,366 & 2,827 \\
\hline 1990 & 25 & 2,087 & 2,367 \\
\hline 1991 & 19 & 1,801 & 1,959 \\
\hline 1992 & 23 & 1,760 & 1,858 \\
\hline 1993 & 21 & 1,884 & 1,933 \\
\hline 1994 & 22 & 2,278 & 2,278 \\
\hline Total & 51 & 22,646 & 28,207 \\
\hline
\end{tabular}


Table C.2. Yearly Sales of Spinoff Technologies

(In Millions of \$) ${ }^{\mathbf{a}}$

\begin{tabular}{|c|c|c|c|c|c|}
\hline \multirow{2}{*}{ Year } & \multirow{2}{*}{$\begin{array}{l}\text { Number of ERIP } \\
\text { Technologies with } \\
\text { Spinoffs in the } \\
\text { Market }\end{array}$} & \multicolumn{2}{|c|}{ Annual Sales } & \multicolumn{2}{|c|}{ Cumulative Sales } \\
\hline & & $\begin{array}{l}\text { Current } \\
\text { Dollars }\end{array}$ & $\begin{array}{c}\text { 1994 } \\
\text { Dollars }\end{array}$ & $\begin{array}{l}\text { Current } \\
\text { Dollars }\end{array}$ & 1994 Dollars \\
\hline 1980 & - & 一 & - & - & - \\
\hline 1981 & 一 & - & - & - & - \\
\hline 1982 & - & - & - & - & - \\
\hline 1983 & - & - & - & - & - \\
\hline 1984 & - & - & - & - & - \\
\hline 1985 & 7 & 5.9 & 8.1 & $5.9^{-}$ & 8.1 \\
\hline 1986 & 8 & 4.7 & 6.3 & 10.6 & 14.4 \\
\hline 1987 & 12 & 6.0 & 7.9 & 16.6 & 22.3 \\
\hline 1988 & 13 & 7.8 & 9.8 & 24.4 & 32.1 \\
\hline 1989 & 13 & 5.4 & 6.4 & 29.8 & 38.5 \\
\hline 1990 & 19 & 6.4 & 7.2 & 36.2 & 45.8 \\
\hline 1991 & 17 & 8.5 & 9.3 & 44.7 & 55.1 \\
\hline 1992 & 18 & 10.7 & 11.3 & 55.4 & 66.4 \\
\hline 1993 & 13 & 8.1 & 8.3 & 63.5 & 74.7 \\
\hline 1994 & 22 & 13.2 & 13.2 & 76.7 & 87.8 \\
\hline Total & 44 & 76.7 & 87.8 & - & - \\
\hline
\end{tabular}




\section{Table C.3. Average Funds Raised per Inventor, by Source (in Thousands of 1994 Dollars)}

\begin{tabular}{|c|c|c|c|c|c|c|c|c|}
\hline & \multicolumn{4}{|c|}{ 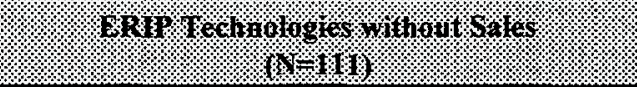 } & \multicolumn{4}{|c|}{ 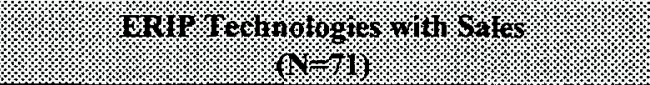 } \\
\hline & 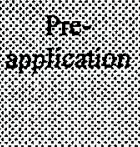 & . & 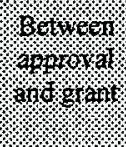 & 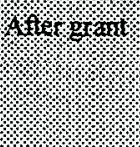 & $3 \%$ & $2^{2}$ & 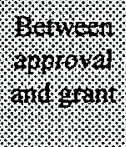 & 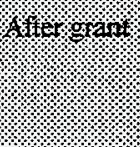 \\
\hline $8+180144$ & $\begin{array}{c}47 \\
(\mathrm{~N}=33)\end{array}$ & $\begin{array}{c}3 \\
(\mathrm{~N}=13)\end{array}$ & $\begin{array}{c}10 \\
(\mathrm{~N}=22)\end{array}$ & $\begin{array}{c}42 \\
(N=31)\end{array}$ & $\begin{array}{c}249 \\
(\mathrm{~N}=26)\end{array}$ & $\begin{array}{c}47 \\
(N=10)\end{array}$ & $\begin{array}{c}21 \\
(\mathrm{~N}=15)\end{array}$ & $\begin{array}{c}87 \\
(N=19)\end{array}$ \\
\hline $1401001 \times 1 \%$ & $\begin{array}{c}5 \\
(N=6)\end{array}$ & $\begin{array}{c}1 \\
(N=3)\end{array}$ & $\begin{array}{c}2 \\
(N=6)\end{array}$ & $\begin{array}{c}3 \\
(N=4)\end{array}$ & $\begin{array}{c}24 \\
(\mathrm{~N}=6)\end{array}$ & $\begin{array}{c}6 \\
(N=5)\end{array}$ & $\begin{array}{c}105 \\
(\mathrm{~N}=10)\end{array}$ & $\begin{array}{c}434 \\
(\mathrm{~N}=19)\end{array}$ \\
\hline / & $\begin{array}{c}27 \\
(\mathrm{~N}=5)\end{array}$ & $\begin{array}{c}21 \\
(\mathrm{~N}=6)\end{array}$ & $\begin{array}{c}29 \\
(\mathrm{~N}=8)\end{array}$ & $\begin{array}{c}40 \\
(\mathrm{~N}=7)\end{array}$ & $\begin{array}{c}7 \\
(\mathrm{~N}=3)\end{array}$ & $\begin{array}{c}4 \\
(\mathrm{~N}=2)\end{array}$ & $\begin{array}{c}3 \\
(\mathrm{~N}=3)\end{array}$ & $\begin{array}{c}264 \\
(\mathrm{~N}=9)\end{array}$ \\
\hline 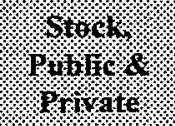 & $\begin{array}{c}0 \\
(\mathrm{~N}=0)\end{array}$ & $\begin{array}{c}32 \\
(N=1)\end{array}$ & $\begin{array}{c}0 \\
(\mathrm{~N}=0)\end{array}$ & $\begin{array}{c}0 \\
(\mathrm{~N}=0)\end{array}$ & $\begin{array}{c}36 \\
(N=2)\end{array}$ & $\begin{array}{c}262 \\
(\mathrm{~N}=3)\end{array}$ & $\stackrel{2}{(N=1)}$ & $\stackrel{2}{2}$ \\
\hline 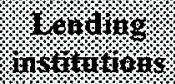 & $\begin{array}{c}0 \\
(\mathbb{N}=0)\end{array}$ & $\begin{array}{c}0 \\
(\mathrm{~N}=0)\end{array}$ & $\begin{array}{c}0 \\
(\mathrm{~N}=0)\end{array}$ & $\begin{array}{c}1 \\
(\mathrm{~N}=1)\end{array}$ & $\begin{array}{c}8 \\
(N=2)\end{array}$ & $\begin{array}{c}36 \\
(\mathrm{~N}=5)\end{array}$ & $\begin{array}{c}8 \\
(N=2)\end{array}$ & $\begin{array}{c}12 \\
(N=4)\end{array}$ \\
\hline therctive & $\begin{array}{c}2 \\
(\mathrm{~N}=3)\end{array}$ & $\begin{array}{c}3 \\
(N=4)\end{array}$ & $\begin{array}{c}1 \\
(\mathrm{~N}=1)\end{array}$ & $\begin{array}{c}128 \\
(N=4)\end{array}$ & $\begin{array}{c}0 \\
(\mathrm{~N}=0)\end{array}$ & $\begin{array}{c}2 \\
(\mathrm{~N}=1)\end{array}$ & $\begin{array}{c}3 \\
(\mathrm{~N}=2)\end{array}$ & $\begin{array}{c}11 \\
(\mathrm{~N}=2)\end{array}$ \\
\hline 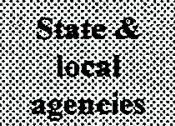 & $\begin{array}{c}4 \\
(\mathrm{~N}=6)\end{array}$ & $\begin{array}{c}1 \\
(N=4)\end{array}$ & $\begin{array}{c}1 \\
(N=3)\end{array}$ & $\begin{array}{c}28 \\
(\mathrm{~N}=8)\end{array}$ & $\begin{array}{c}3 \\
(N=3)\end{array}$ & $\begin{array}{c}0 \\
(\mathrm{~N}=0)\end{array}$ & $\begin{array}{c}3 \\
(\mathrm{~N}=2)\end{array}$ & $\begin{array}{c}7 \\
(\mathrm{~N}=3)\end{array}$ \\
\hline 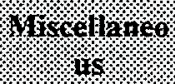 & $\begin{array}{c}0 \\
(\mathrm{~N}=0)\end{array}$ & $\begin{array}{c}0 \\
(\mathrm{~N}=0)\end{array}$ & $\begin{array}{c}0 \\
(\mathrm{~N}=0)\end{array}$ & $\begin{array}{c}1 \\
(N=3)\end{array}$ & $\begin{array}{c}0 \\
(\mathrm{~N}=0)\end{array}$ & $\begin{array}{c}0 \\
(\mathrm{~N}=1)\end{array}$ & $\begin{array}{c}0 \\
(\mathrm{~N}=0)\end{array}$ & $\begin{array}{c}6 \\
(N=1)\end{array}$ \\
\hline Toras & $\begin{array}{c}85 \\
(\mathrm{~N}=53)\end{array}$ & $\begin{array}{c}59 \\
(\mathrm{~N}=31)\end{array}$ & $\begin{array}{c}42 \\
(\mathrm{~N}=40)\end{array}$ & $\begin{array}{c}244 \\
(\mathrm{~N}=58)\end{array}$ & $\begin{array}{c}327 \\
(\mathrm{~N}=42)\end{array}$ & $\begin{array}{c}358 \\
(\mathrm{~N}=27)\end{array}$ & $\begin{array}{c}146 \\
(\mathrm{~N}=35)\end{array}$ & $\begin{array}{c}822 \\
(\mathrm{~N}=58)\end{array}$ \\
\hline
\end{tabular}

ERIP grants, non-financial support, and short-term debt are excluded from this table.

Numbers are average amounts of funding raised by the 182 grant recipients surveyed in 1995 . "N" represents the number of inventions that have attracted funding from a particular source. For instance, the 111 without sales raised an average of $\$ 47,000$ from personal sources before applying to the program. But only 33 of these 111 inventions actually raised personal funding. 


\section{INTERNAL DISTRIBUTION}

$\begin{aligned} \text { 1-5. } & \text { K. R. Ballew } \\ 6 . & \text { L. G. Berry } \\ 7 . & \text { D. J. Bjornstad } \\ 8 . & \text { R. B. Braid } \\ 9 . & \text { M. A. Brown } \\ \text { 10. } & \text { G. E. Courville } \\ 11 . & \text { T. R. Curlee } \\ 12 . & \text { C. A. Franchuk } \\ 13 . & \text { W. Fulkerson } \\ 14 . & \text { S. G. Hildebrand } \\ 15 . & \text { E. Hirst } \\ \text { 16. } & \text { R. B. Honea } \\ \text { 17. } & \text { D. W. Jones } \\ 18 . & \text { C. H. Kerley } \\ 19 . & \text { P. N. Leiby }\end{aligned}$

20. W. Martin

21. V.C. Mei

22. D. E. Reichle

23. C. G. Rizy

24. A. C. Schaffhauser

25. M. Schweitzer

26. R. B. Shelton

27. W. B. Snyder

28. T. J. Wilbanks

29. C. R. Wilson

30. Central Research Library

31. Document Reference Section

32-33. Laboratory Records

34. Laboratory Records-RC

35. ORNL Patent Office

\section{EXTERNAL DISTRIBUTION}

36. Lilia A. Abron, President, PEER Consultants, P.C., 1000 N. Ashley Drive, Suite 312, Tampa, Florida 33602

37. Thomas E. Drabek, Professor, Department of Sociology, University of Denver, Denver, Colorado 80208-0209

38-62. P. M. Hayes, Inventions and Innovation Programs, U.S. Department of Energy, EE-52, 5E-052, 1000 Independence Ave., SW, Washington, DC 20585.

63. H. C. Livesay, Clifford A. Taylor Professor in Liberal Arts, Department of History, Texas A\&M University, College Station, TX 77843-1227

64. D. S. Lux, Bryant College, 450 Douglas Pike, Smithfield, RI 02917-1284

65. C. D. MacCracken, President, Calmac Manufacturing Corporation, 101 West Sheffield Avenue, P.O. Box 710, Englewood, NJ 07631

66. R. Nader, P.O. Box 19367, Washington, DC 20036

67. Office of Assistant Manager for Energy Research and Development, DOE-ORO, P.O. Box 2001, Oak Ridge, TN 38831-8600

68-69. OSTI, U.S. Department of Energy, P.O. Box 62, Oak Ridge, TN 37831.

70. R. W. Peplies, Department of Geography, East Tennessee State University, Johnson City, TN 37814.

71. Mary Rawlins, Department of Energy, P.O. Box 2008, DOE Field Office, Oak Ridge, TN 37831-6269.

72-73 . M. Rorke, Mohawk Research Corp., 915 Willowleaf Way, Rockville, MD 20854-317.

74. J. B. Shrago, Director, Office of Technology Transfer, 405 Kirkland Hall, Vanderbilt University, Nashville, TN 37240 
75. George F. Sowers, P.E., Senior Vice President, Law Companies Group, Inc., 114 Townpark Drive, Suite 250, Kennesaw, Georgia 30144-5599

76. Susan F. Tierney, The Econimc Resource Group, Inc., One Mifflin Place, Cambridge, MA 02138

77. C. Michael Walton, Ernest H. Cockrell Centennial Chair in Engineering and Chairman, Department of Civil Engineering, University of Texas at Austin, Austin, Texas 78712-1076

78-300. Marilyn A. Brown, Deputy Director, Energy Efficiency and Renewable Energy Program, Oak Ridge National Laboratory, P.O. Box 2008, 4500N, MS-6186, Oak Ridge, TN 37831-6186. 